UMUERSIIAS UDAYAMA

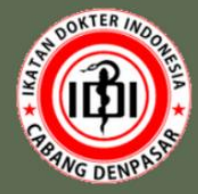

BUNGA RAMPAI

SEHAT DAN BAHAGIA

SELAMA MENJALANI

ISOLASI MANDIRI

GOVID-19

Tim Penyusun: Fakultas Kedokteran Universitas Udayana dan

Ikatan Dokter Indonesia Cabang Denpasar

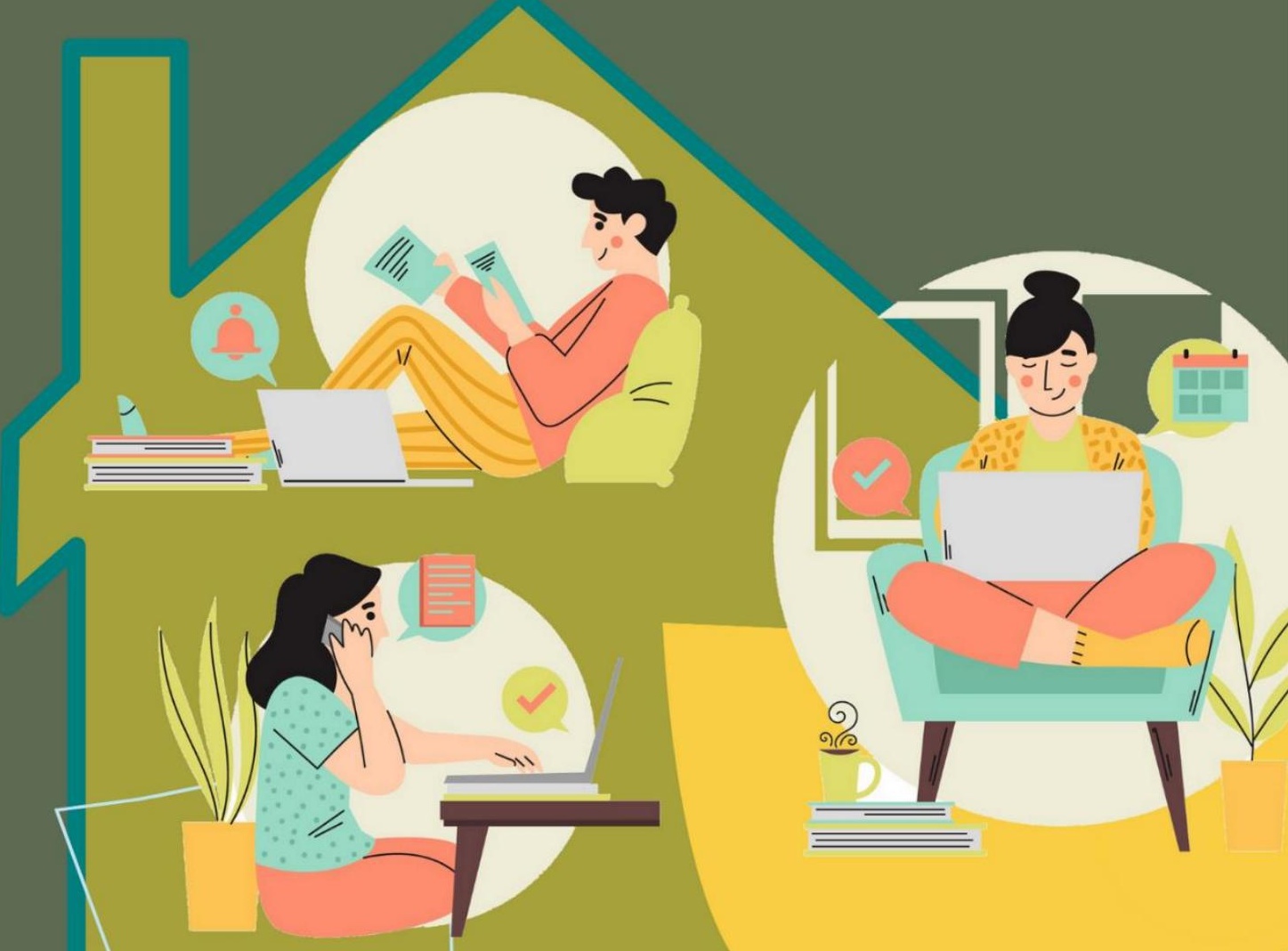




\title{
SEHAT DAN BAHAGIA SELAMA MENJALANI ISOLASI MANDIRI COVID-19
}

\author{
Tim Editor: \\ Prof. Dr. dr. I Ketut Suyasa, SpB, SpOT(K) \\ dr. I Ketut Widiyasa, MPH
}

Kontributor:

Prof. Dr. dr. I Ketut Suyasa, SpB, SpOT(K)

Prof. Dr. dr. RA Tuty Kuswardhani, SpPD-KGer

Prof. Dr. dr. I Wayan Weta, MS., SpGK

Prof. Dr. dr. Tjokorda Gde Bagus Mahadewa, Sp.BS(K)

Prof. Dr. dr. AA Wiradewi Lestari, SpPK(K)

Dr. dr. Gde Ngurah Indraguna Pinatih, MSc., SpGK

Dr. dr. Anak Agung Sagung Sawitri, MPH

Dr. dr. Ni Kadek Mulyantari, SpPK(K)

Dr. dr. I Made Susila Utama, SpPD, K-PTI, FINASIM

Dr. dr. I Ketut Agus Somia, SpPD, K-PTI, FINASIM

Dr. dr. I Gusti Putu Suka Aryana, Sp. PD, K-Ger, FINASIM

Dr. Ni Made Swasti Wulanyani, S.Psi., M.Erg., Psikolog

Dr. dr. Putu Ayu Asri Damayanti, S.Ked, M.Kes

Dr. dr. Ni Made Susilawathi, SpS(K)

Dr. dr. Kumara Tini, SpS(K), FINS, FINA

dr. Pande Putu Januraga, M.Kes, DrPH

I Gusti Ayu Diah Fridari, S.Psi., M.Psi., Ph.D., Psikolog

dr. Ni Ketut Sri Diniari, SpKJ(K)

dr. I Gusti Ayu Indah Ardani, Sp.KJ (K)

dr. Ni Luh Putu Eka Arisanti, SpP(K)

dr. I Gede Ketut Sajinadiyasa, SpPD-KP dr. Cokorda Wahyu Purnamasidhi, SpPD, MBiomed dr. Pande Made Andikayasa, Sp.P

dr. Gede Oky Aryanthana, Sp.P

dr. Agustinus I Wayan Harimawan, MPH, SpGK

dr. I Wayan Gede Sutadarma, M.Gizi., SpGK

dr. Ni Ketut Sumartini, M.Kes., SpGK

dr. Syuma Adhy Awan, M.Kes., SpGK

dr. Putu Roseputri Bajirani, SpGK

dr. Ni Made Dwi Asti Lestari, M.Kes., SpGK

dr. I Gusti Ngurah Pramesemara, S.Ked, M.Biomed, Sp.And dr. I Made Oka Negara, S.Ked, M.Biomed, FIAS

Ns. Desak Made Widyanthari, S.Kep., M.Kep., SpKep.M.B

Ari Wibawa,S.St.Ft, M.Fis

Ni Made Ari Wilani, S.Psi., M.Psi., Psikolog

Putu Nugrahaeni Widiasavitri, S.Psi., M.Psi., Psikolog Komang Rahayu Indrawati, S.Psi., M.Si., Psikolog

Ns. Putu Oka Yuli Nurhesti, S.Kep., MM., M.Kep.

dr. I Made Dwi Ariawan, S.Ked

dr. I Made Kristya Permana, S.Ked

dr. Gede Benny Setia Wirawan, S.Ked

\section{BASWARA}

PENERBIT BASWARA PRESS by PANUDUH ATMA WARAS Jl. ByPass Ngurah Rai Nomor: 888 xx, Denpasar, Bali, Indonesia

(0361) 6209990; (+62)82236180725

info@baswarapress.com panuduhatmawaras@gmail.com 


\title{
SEHAT DAN BAHAGIA SELAMA MENJALANI ISOLASI MANDIRI COVID-19
}

\author{
Tim Editor: \\ Prof. Dr. dr. I Ketut Suyasa, SpB, SpOT(K) \\ dr. I Ketut Widiyasa, MPH
}

Kontributor:

Prof. Dr. dr. I Ketut Suyasa, SpB, SpOT(K)

Prof. Dr. dr. RA Tuty Kuswardhani, SpPD-KGer

Prof. Dr. dr. I Wayan Weta, MS., SpGK

Prof. Dr. dr. Tjokorda Gde Bagus Mahadewa, Sp.BS(K)

Prof. Dr. dr. AA Wiradewi Lestari, SpPK(K)

Dr. dr. Gde Ngurah Indraguna Pinatih, MSc., SpGK

Dr. dr. Anak Agung Sagung Sawitri, MPH

Dr. dr. Ni Kadek Mulyantari, SpPK(K)

Dr. dr. I Made Susila Utama, SpPD, K-PTI, FINASIM

Dr. dr. I Ketut Agus Somia, SpPD, K-PTI, FINASIM

Dr. dr. I Gusti Putu Suka Aryana, Sp. PD, K-Ger, FINASIM

Dr. Ni Made Swasti Wulanyani, S.Psi., M.Erg., Psikolog

Dr. dr. Putu Ayu Asri Damayanti, S.Ked, M.Kes

Dr. dr. Ni Made Susilawathi, SpS(K)

Dr. dr. Kumara Tini, SpS(K), FINS, FINA

dr. Pande Putu Januraga, M.Kes, DrPH

I Gusti Ayu Diah Fridari, S.Psi., M.Psi., Ph.D., Psikolog

dr. Ni Ketut Sri Diniari, SpKJ(K)

dr. I Gusti Ayu Indah Ardani, Sp.KJ (K)

dr. Ni Luh Putu Eka Arisanti, SpP(K)

dr. I Gede Ketut Sajinadiyasa, SpPD-KP

\author{
dr. Cokorda Wahyu Purnamasidhi, SpPD, MBiomed \\ dr. Pande Made Andikayasa, Sp.P \\ dr. Gede Oky Aryanthana, Sp.P \\ dr. Agustinus I Wayan Harimawan, MPH, SpGK \\ dr. I Wayan Gede Sutadarma, M.Gizi., SpGK \\ dr. Ni Ketut Sumartini, M.Kes., SpGK \\ dr. Syuma Adhy Awan, M.Kes., SpGK \\ dr. Putu Roseputri Bajirani, SpGK \\ dr. Ni Made Dwi Asti Lestari, M.Kes., SpGK \\ dr. I Gusti Ngurah Pramesemara, S.Ked, M.Biomed, Sp.And \\ dr. I Made Oka Negara, S.Ked, M.Biomed, FIAS \\ Ns. Desak Made Widyanthari, S.Kep., M.Kep., SpKep.M.B \\ Ari Wibawa,S.St.Ft, M.Fis \\ Ni Made Ari Wilani, S.Psi., M.Psi., Psikolog \\ Putu Nugrahaeni Widiasavitri, S.Psi., M.Psi., Psikolog \\ Komang Rahayu Indrawati, S.Psi., M.Si., Psikolog \\ Ns. Putu Oka Yuli Nurhesti, S.Kep., MM., M.Kep. \\ dr. I Made Dwi Ariawan, S.Ked \\ dr. I Made Kristya Permana, S.Ked \\ dr. Gede Benny Setia Wirawan, S.Ked
}

$\begin{array}{ll}\text { ISBN Cetak } & : 9786239747343 \\ \text { ISBN (PDF) } & : 9786239747336 \\ \text { DOI } & : \text { https://doi.org/10.53638/9786239747336 }\end{array}$

Copyright @Agustus 2021

Ukuran: $21 \mathrm{~cm} \times 29.7 \mathrm{~cm}$; iv + 136 halaman

Hak Cipta dilindungi oleh Undang-Undang. Pertamakali diterbitkan di Indonesia dalam Bahasa Indonesia oleh Baswara Press. Penggunaan material dalam karya ini diatur dalam Lisensi Publik Creative Commons 4.0 Atribusi-NonKomersial-TanpaTurunan (CC-BY-ND). Pengguna dapat mengutip konten dalam karya ini dengan memberi kredit yang sepantasnya kepada penulis asli karya ini. Dilarang menggunakan karya ini untuk kepentingan komersial dalam bentuk apapun. Dilarang mengubah dan menyebarluaskan isi karya ini dalam bentuk apa pun tanpa izin tertulis dari penulis.

Terbit daring, Agustus 2021

PENERBIT BASWARA PRESS by PANUDUH ATMA WARAS

JI. ByPass Ngurah Rai Nomor: 888 xx, Denpasar, Bali -Indonesia

(0361) 6209990; (+62)82236180725

info@baswarapress.com

panuduhatmawaras@gmail.com 


\section{KATA PENGANTAR \\ DEKAN FAKULTAS KEDOKTERAN \\ UNIVERSITAS UDAYANA}

Om Swastyastu,

Pandemi COVID-19 yang sedang melanda dunia dan juga Indonesia memperkenalkan kita pada berbagai kenyataan baru kehidupan. Salah satu perubahan besar yang kita hadapi bersama adalah bagaimana hidup dalam isolasi mandiri jika kita kurang beruntung dan terinfeksi COVID-19. Dalam melaksanakan isolasi mandiri, tidak jarang kita kesulitan menyesuaikan diri ke dalam situasi hidup yang baru.

Berbagai hal memerlukan penyesuaian selama menjalani isolasi mandiri, mulai dari pemenuhan kebutuhan hidup sehari-hari, bagaimana mendapatkan perawatan medis, hingga menjaga kesehatan mental selama menjalani isolasi mandiri. Pada saat yang sama, seseorang yang menjalani isolasi mandiri harus tetap taat pada berbagai protokol kesehatan.

Menjawab kebutuhan ini, Fakultas Kedokteran Universitas Udayana bekerja sama dengan Ikatan Dokter Indonesia Cabang Denpasar dalam melaksanakan TELEKODINA, suatu platform telekonseling yang bertujuan membantu peserta isolasi mandiri untuk menjalani isolasi mandirinya dengan efektif, sehat, dan bahagia. Adapun bunga rampai ini disusun untuk merangkum berbagai informasi dan hasil diskusi yang diperoleh dalam kegiatan tersebut. Semoga informasi yang disusun dalam bunga rampai ini bermanfaat bagi akademisi, klinisi, maupun masyarakat awam yang sedang menggeluti isolasi mandiri.

Om Shanti, Shanti, Shanti, Om

Dokan. Fakultas Kedokteran

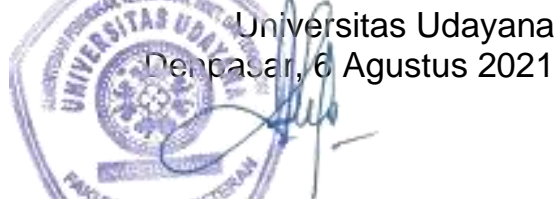

Prof. Dr. dr. I Ketut Suyasa, SpB, SpOT(K) 


\section{KATA PENGANTAR \\ KETUA IKATAN DOKTER INDONESIA \\ CABANG DENPASAR}

Telah hampir dua tahun dunia harus berjuang melawan ganasnya dampak kesehatan dan ikutannya dari Pandemi COVID-19 ini. Pada sektor kesehatan, kita bersama-sama telah menjadi saksi hebatnya dampak pandemi, termasuk tingginya angka penularan, kesakitan dan bahkan kematian di masyarakat. Angka transmisi yang tinggi dan keterbatasan perawatan di rumah sakit mengakibatkan tingginya kasus COVID-19 yang menjalani perawatan isolasi secara mandiri.

Tentu, isolasi mandiri ini memiliki konsekuensinya. Pemantauan dan pengawasan pasien yang menjalani isolasi mandiri harus ditingkatkan kualitasnya sehingga dapat mencegah keterlambatan penanganan kasus-kasus sedang dan berat. Untuk membantu pemantauan dan pengawasan progresifitas penyakit selama isolasi mandiri ini, baik pasien, keluarga maupun petugas kesehatan harus memiliki pemahaman yang sama.

Untuk itu, saya mewakili segenap Pengurus Ikatan Dokter Indonesia Cabang Denpasar sangat bangga telah dilibatkan oleh Fakultas Kedokteran Universitas Udayana dalam kegiatan-kegiatan penanganan Covid-19 di Kota Denpasar maupun Bali pada umumnya. Salah satu kegiatan tersebut adalah pelaksanaan Program Layanan Telekonseling Kesehatan bagi Pasien Isolasi Mandiri yang berlangsung sejak 17 Juli 2021. Sebagai lanjutan kegiatan tersebut, disepakati untuk menyusun sebuah buku panduan bagi pasien yang sedang menjalani isolasi mandiri.

Akhir kata, saya menyampaikan terima kasih untuk Bapak Dekan FK Unud, seluruh Sejawat Dokter, Psikolog, Perawat dan Fisioterapis yang terlibat dalam penyusunan buku ini. Semoga buku panduan yang diberi judul "Sehat dan Bahagia Selama Menjalani Isolasi Mandiri COVID19" ini dapat bermanfaat bagi seluruh warga, dan bahkan tenaga kesehatan yang dilibatkan dalam pelaksanaan isolasi mandiri.

Denpasar, 6 Agustus 2021

Ketua Ikatan Dokter rondorgesia Gabang Denpasar,

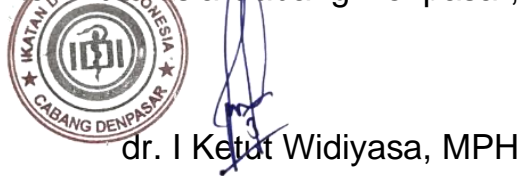




\section{DAFTAR ISI}

i. Kata Pengantar Dekan Fakultas Kedokteran

Universitas Udayana

ii. Kata Pengantar Ketua Ikatan Dokter Indonesia

Cabang Denpasar

iii. Daftar Isi

lii

1. Pendahuluan: Protokol Kesehatan Panglima Perang

Selama Pandemi COVID-19 (IK Suyasa)

2. Situasi Isolasi Mandiri di Bali (GBS Wirawan, PP

Januraga)

3. Laboratorium COVID-19 untuk Pasien yang Menjalani Isolasi Mandiri (NK Mulyantari, AAW Lestari)

4. Persyaratan Isolasi Mandiri COVID-19, Kapan Dimulai dan Diakhiri (IMS Utama, IKA Somia, CW Purnamasidhi)

5. Sarana dan Prasarana Isolasi Mandiri (IMD Ariawan, AAS Sawitri)

6. Gejala dan Tanda Umum yang Harus Diperhatikan Selama Isolasi Mandiri (PM Andikayasa, GO

Aryanthana, NLPE Arisanti, IGK Sajinadiyasa)

7. Latihan Fisik Selama Isolasi Mandiri (A Wibawa) ......... 35

8. Kesehatan Psikologis Dalam Pandemi (NMS

Wulanyani, IGAD Fridari, NMA Wilani, PN Widiasavitri, KR Indrawati, AS Immanuel, MP Bajirani) 
9. Mengelola Kesehatan Mental Selama Isolasi Mandiri (IGAI Ardani, NKS Diniari)

10. Nutrisi Untuk Warga yang Isolasi Mandiri (AIW Harimawan, GNI Pinatih, WG Sutadarma, IW Weta, NK Sumartini, SA Awan, PR Bajirani, NMDA Lestari) ... 58

11. Kesehatan Reproduksi dan Seksual Selama Isolasi Mandiri (IGN Pramesemara, MO Negara)

12. Perawatan Diri pada Pasien COVID-19 (DM Widyanthari, POY Nurhesti, PAA Damayanti)

13. Serba-serbi Isolasi Mandiri pada Lanjut Usia yang Terinfeksi COVID-19 (IGPS Aryana, IMK Permana, RAT Kuswardhani)

14. COVID-19 dan Cidera Kepala (TGB Mahadewa) ......... 115

15. Panduan Isoman Problem Neurologi Pada Pasien COVID-19 (NM Susilawathi, K Tini)

16 Sintesis dan Penutup 135 


\section{PENDAHULUAN}

\section{PROTOKOL KESEHATAN PANGLIMA PERANG SELAMA PANDEMI COVID-19}

I Ketut Suyasa

Tiada terasa 16 bulan kita sudah mengalami masa pandemic COVID-19, situasi yang sudah meluluhlantakkan berbagai aspek tatanan kehidupan masyarakat Indonesia bahkan hampir di seluruh belahan dunia. Ini menjadi tantangan kita bersama untuk bisa lepas dari situasi krisis dan beradaptasi dengan kondisi ini dalam tatanan kehidupan baru.

Beberapa bulan yang lalu, melandainya kasus Covid -19 di Bali sempat membuat kita lega. Tetapi begitu meledaknya kasus di India membuat kita harus semakin waspada. Bukan tidak mungkin, itu merupakan alarm bagi kita yang akan menghadapi hal yang serupa, mengingat sudah terbukanya beberapa penerbangan menuju dan keluar Bali. Menyadari situasi ini, Fakultas Kedokteran Universitas Udayana telah melakukan berbagai kegiatan antisipasi. Pada tanggal 29 Mei 2021 dengan menggandeng Pemerintah, TNI - POLRI dan gojek, FK Unud mengakselerasi penguatan protokol kesehatan dengan melepas Mahasiswa Fakultas Kedokteran Universitas Udayana sebagai Duta Perubahan Perilaku, Duta Protokol Kesehatan dan Tracing. Kegiatan yang dilepas oleh Bapak Sekda Propinsi Bali/Ketua Harian Satgas Penanggulangan COVID-19 Propinsi Bali, Bapak Pangdam IX Udayana yang diwakili Bapak Kasdam dan Bapak Kapolda Bali ini menyasar masyarakat di PPKM Mikro yang dikoordinir langsung oleh Bapak KaroOps Polda Bali. 
Tidak cukup dengan kegiatan tersebut, menyadari bahwa kepatuhan akan protokol kesehatan merupakan kebutuhan essensial untuk melindungi masyarakat kita, maka Fakultas Kedokteran Universitas Udayana kembali menggelar webinar Membumikan Pesan lbu dengan menghadirkan narasumber Ibu Ketua Tim Penggerak PKK Propinsi Bali yang diwakili oleh sekretaris dan Dr.dr. Anak Agung Sagung Sawitri,MPH sebagai pembicara dan kegiatan ini dihadiri oleh seluruh tim penggerak PKK se- Bali, Dharma wanita, Ibu- ibu dari Persit Kartika Candra Kirana Kodam IX/ Udayana dan Korem 163/Wirasatya, PD Bhayangkari Polda Bali dan PC Bhayangkari Polresta Denpasar, serta lbu -lbu dosen di lingkungan FK unud. Kegiatan ini menekankan pentingnya kepatuhan protokol kesehatan untuk melindungi kita semua di masa pandemi ini. Disamping itu, peran lbu yang sentral di rumah tangga diharapkan mampu menjadi penggerak kepatuhan akan protokol kesehatan bagi anggota keluarga, sehingga sangat tepat bila PPKM di lingkungan keluarga juga ditingkatkan.

Kepatuhan pada protokol kesehatan yaitu memakai masker, mencuci tangan, menjaga jarak, menghindari kerumunan, mengurangi mobilitas dan mengikuti Vaksinasi, saat ini menjadi panglima perang kita selama pandemi covid -19 untuk memutus rantai penularan. Demikian pula gerakan $3 \mathrm{~T}$; Tracing, Testing dan Treatment merupakan langkah langkah mandatori dalam penanganan COVID-19. Semua ini memerlukan kerja sama baik dari seluruh elemen masyarakat.

Meningkatnya kasus di Bali di tengah pelaksanaan PPKM Mikro, sebagai akibat dari rendahnya kepatuhan kita dalam melaksanakan protokol kesehatan. Hal ini dapat kita lihat dari banyaknya masyarakat yang abai pada prokes. Disusul kemudian dengan peningkatan kasus 
terkonfirmasi positif yang mencapai di atas seribu, menyebabkan ditetapkannya Bali sebagai daerah penerapan PPKM darurat yang kemudian dilanjutkan dengan PPKM level 4. Hal ini harus menjadi atensi dan perlu upaya kita bersama untuk mengambil langkah - langkah agar Bali bisa kembali ke zona hijau.

Tingginya kasus dan merebaknya varian delta, bahkan tumbangnya beberapa nakes mengetuk hati saya selaku Pimpinan Fakultas Kedokteran Universitas Udayana untuk berbuat sesuatu agar bisa berkontribusi kembali dalam upaya melandaikan kasus COVID-19 di Bali. Kita tidak cukup hanya dengan pelayanan di rumah sakit saja, melainkan juga harus menggelorakan upaya - upaya pencegahan, sehingga rumah sakit tidak menjadi kolaps karena tingginya kasus yang mengakibatkan meningkatnya tingkat hunian rumah sakit dan banyaknya tenaga kesehatan yang terpapar baik dirawat maupun menjalani isolasi.

Saya masih ingat saat itu tanggal 11 juli 2021, saya sempat berdiskusi dengan teman - teman antara lain Dr. Ni Made Swasti Wulanyani,S.Psi, MEng, dr. Gusti Ayu Putu Nilawati,SpA(K) dan dr. Ketut Widiyasa, MPH. Kami berbincang bagaimana cara mengedukasi masyarakat tentang kepatuhan protokol kesehatan secara luas. Kebetulan saat itu dr. Ketut Widiyasa, MPH selaku Ketua IDI Cabang Denpasar menawarkan media ZOOM, karena IDI berlangganan. Bagai gayung bersambut, saya pun langsung melontarkan ide untuk melaksanakan telekonsultasi. SDM pematerinya merupakan staf dari FK Unud dan tidak menutup kemungkinan bisa juga dari anggota IDI dengan Cabang Denpasar, sedangkan host dan mekanisme penyelengaraan dimotori teman - teman IDI Cabang Denpasar. Akhirnya kami sepakat dan tanggal 12 juli saya membuat WAG Group Telekonseling dengan 
mengajak beberapa teman staf FK Unud yang pada akhirnya semakin banyak teman - teman yang berkenan terlibat. Ini membuktikan betapa besar rasa empati dan kepedulian teman - teman kita untuk masyarakat. Bahkan selain teman sejawat dokter, ikut juga bergabung tim dari psikologi, tim fisioterapi dan tim keperawatan FK Unud untuk menjadi pemateri dalam acara telekonseling yang digagas ini.
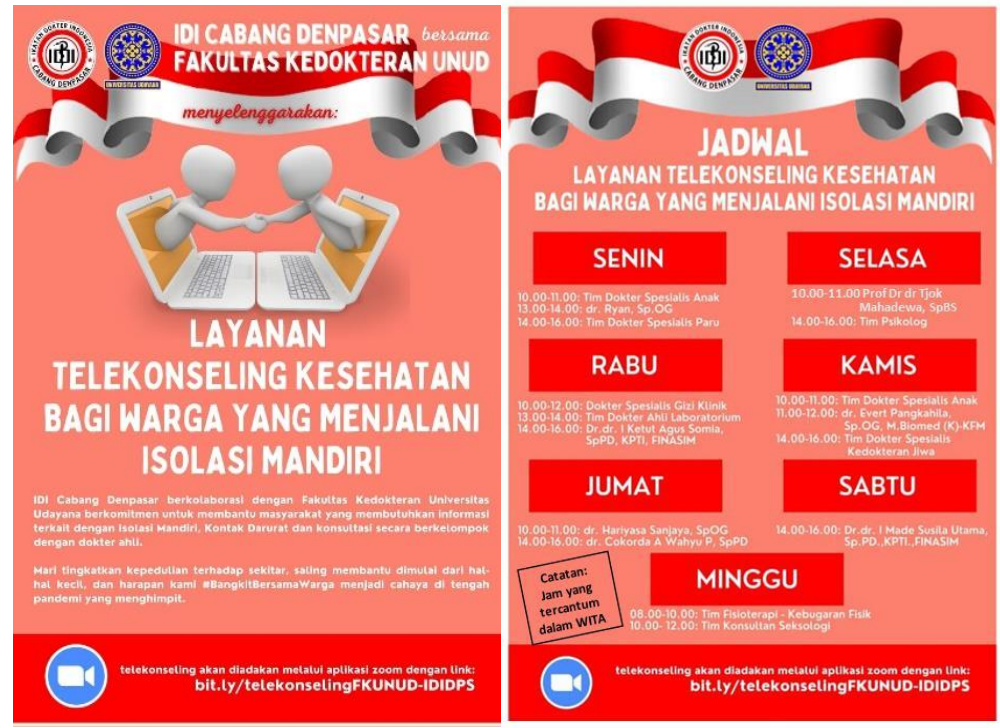

Gambar 1.1. Kegiatan TELEKODINA.

Kegiatan edukasi berbasis IT dalam bentuk kegiatan telekonsultasi ini tidak berbayar bagi masyarakat. Telekonseling ini kemudian kami beri nama TELEKODINA (Telekonseling IDI Cabang Denpasar dan FK Universitas Udayana). Kegiatan ini diampu oleh Staf Fakultas Kedokteran Universitas Udayana dan Anggota IDI Cabang Denpasar, secara bergiliran setiap harinya, dibuka secara resmi oleh Ketua Harian Satgas 
Penaggulanan COVID-19 Propinsi Bali, Bapak Dewa Made Indra pada tanggal 17 Juli 2021.
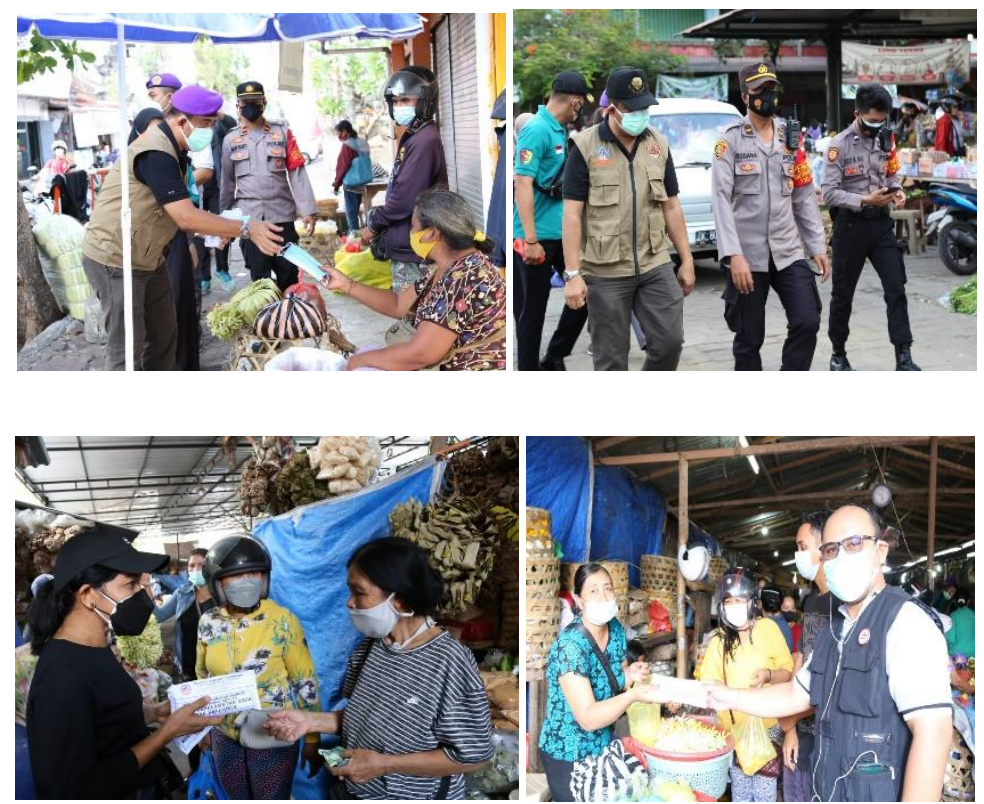

Gambar 1.2. Kegiatan pembagian masker di pasar.

Sebagai bentuk dari edukasi penggunaan masker dan kepatuhan protokol kesehatan, kembali Fakultas Kedokteran Unud menggandeng Resimen Mahasiswa Ugracena dan IDI cabang Denpasar terjun ke pasar - pasar membagikan masker kepada para pedagang sekaligus mengedukasi cara penggunaan masker pada tanggal 31 juli 2021. Kami pun turun bersama mengedukasi para pedagang di Pasar Sanglah, Pasa Badung, Pasar Wangaya dan Pasar Kereneng sambil mebagikan masker dan mengedukasi cara penggunaan masker yang benar. 
Melihat makin tingginya kasus di Bali, kembali saya merasa terusik, kemudian melakukan pendekatan dengan Bapak Kapolda Bali Irjen Pol Drs. Putu Jayan Danu Putra, S.H.M.SI, dan beliau mengajak kami untuk berkolaborasi meningkatkan tracing dan testing. Ajakan ini kami respon positif, dan kemudian Bapak Kapolda Bali mengutus KaroOps Polda Bali Kombes Pol. Firman Nainggolan, S.H.,M.H. dan KasiOps Kasrem 163/ Wirasataya Kol. Kav, I Made Bagus menemui saya di Fakultas Kedokteran Universitas Udayana membahas rencana bantuan tenaga dokter residen dan mahasiswa FK UNUD untuk memperkuat tenaga tracing dan testing di Bali.

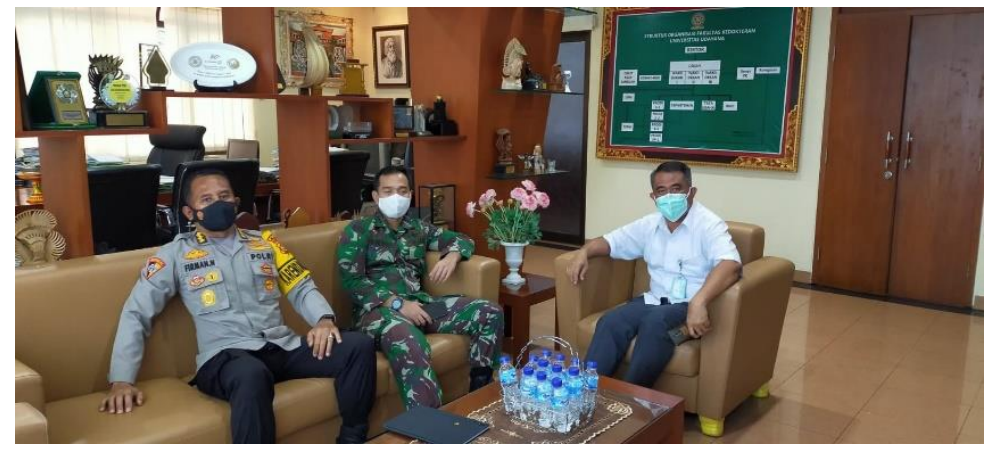

Gambar 1.3. Pertemuan kolaborasi lintas sektoral.

Persiapan pun segera dilakukan bahkan untuk itu, FK UNUD bersama IDI Cabang Denpasar melaksanakan Workshop Vaksinator dan pembekalan tenaga konselor bagi pasien COVID - 19 yang menjalani isolasi pada tanggal 31 Juli - 1 Agustus 2021. Kegiatan yang berlangsung 3 hari ini diakhiri dengan pelatihan cara pengambilan swab, untuk mendukung pelaksanaan tugas tracing dan testing. 
Akhirnya tanggal 4 Agustus 2021 pada rapat daring yang dipimpin langsung oleh Bapak Komandan Korem 163/Wirasatya Brigjen TNI Hussein Sagaf, kami serahkan 143 dokter residen dan 61 orang mahasiswa dari Prodi Kesehatan masyarakat FK Unud untuk memperkuat tim tracing dan testing, yang selanjutnya diserahkan ke Dandim Badung untuk disebar ke masing - masing Koramil bergabung dengan TNI - Polri dan Puskesmas setempat untuk melaksanakan tracing dan testing di daerah Kabupaten Badung dan Kota Denpasar.

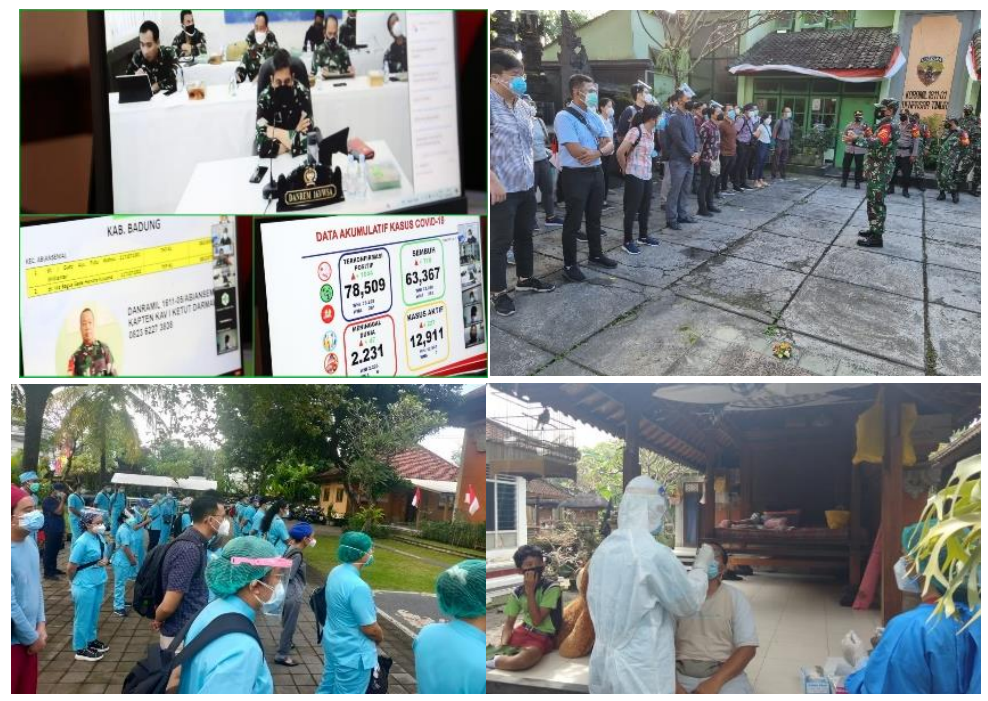

Gambar 1.4. Kegiatan kolaborasi tracing dan testing.

Gencarnya tracing dan testing harus diikuti dengan kepatuhan melaksanakan protokol kesehatan untuk menekan laju penularan COVID-19. Jangan pernah lelah untuk melakukan edukasi dan mengingatkan protokol kesehatan. 


\section{KITA BOLEH LELAH TETAPI JANGAN SAMPAI KALAH}

\# JAGA DIRI,\# JAGA KELUARGA,\# JAGA BANGSA ,\#JAGA NEGARA 


\section{SITUASI ISOLASI MANDIRI DI BALI}

Gede Benny Setia Wirawan, Pande Putu Januraga

Isolasi mandiri (isoman) merupakan suatu kenyataan kehidupan di masa pandemi COVID-19 ini. Sebagian besar orang yang terinfeksi COVID-19 mengalami gejala ringan atau sedang yang tidak memerlukan perawatan di rumah sakit. Sementara itu, dalam gelombang kedua pandemi COVID-19 di Indonesia, jumlah orang yang menjalani isoman juga ditambah dengan penderita dengan indikasi rawat inap yang tidak dapat dirawat karena tingkat okupansi rumah sakit yang tinggi.

Untuk mengetahui situasi orang-orang yang menjalani isoman, Fakultas Kedokteran Universitas Udayana dan Ikatan Dokter Indonesia Cabang Denpasar melakukan pengumpulan data melalui survey online selama pelaksanaan TELEKODINA. Hasilnya terdapat 41 orang responden valid di mana $70,7 \%$ di antaranya merupakan perempuan dengan median usia 32 tahun (interquartile range 27 - 35). Sebanyak $56 \%$ responden berpendidikan D4/S1 dan $17.1 \%$ berpendidikan D1/D2/D3.

Hasil survey tersebut mengidinkasikan bahwa isoman memberikan dampak yang cukup signifikan terhadap situasi ekonomi penderita COVID-19. Sebanyak 7,3\% responden mengaku kehilangan pekerjaan karena COVID-19 dan 48,8\% mengaku mengalami penurunan penghasilan. Sebanyak $50 \%$ dari orang yang mengaku mengalami penurunan penghasilan melaporkan penurunan penghasilan sebesar 30 $50 \%$ dibandingkan sebelum menjalani isoman. 
Banyak peserta juga melaporkan ketidaksiapan untuk menyesuaikan situasi hidup dengan persyaratan isoman. Dari survey diketahui bahwa sebanyak 34\% responden melaporkan kesulitan memenuhi kebutuhan sehari-hari selama pandemi. Ketidaksiapan untuk hidup dalam situasi isoman juga dapat dilihat dari pengaturan rumah tangga di mana 12,2\% mengaku berbagi kamar mandi dengan anggota rumah tangga dengan status COVID-19 negatif atau tidak diketahui. Sebanyak $17,1 \%$ juga mengaku berbagi ruang makan dan dapur dengan anggota rumah tangga dengan status COVID-19 negatif atau tidak diketahui. Selain itu, masih terdapat repsonden peserta isoman yang mengaku keluar rumah untuk bekerja $(2 \%)$, belanja kebutuhan seharihari (4\%), dan membeli obat di apotek (7\%). Situasi ini tidak ideal karena membuka risiko penularan pada anggota rumah tangga lainnya dan juga masyarakat secara luas.

Kurangnya kesiapan menjalani isoman juga dapat dilihat dari kelengkapan peralatan dan prasarana medis yang dilaporkan responden. Sebanyak 9\% responden masing-masing melaporkan tidak memiliki obat demam dan batuk selama menjalani isoman. Selain itu, sebanyak $7 \%$ mengaku tidak memiliki thermometer dan 29\% tidak memiliki pulse oximetry untuk mengukur kadar oksigen darah. Ketersediaan obatobatan dan prasarana yang tidak adekuat membatasi kemampuan perawatan diri selama menjalani isoman, meningkatkan risiko perburukan kondisi yang terlambat disadari.

Pelaksanaan isoman juga terlihat mempengaruhi kesehatan mental penderita. Sebanyak 32\% responden mengaku merasa tertekan selama menjalani isoman dan $37 \%$ merasa kesepian. Selain itu, penapisan dengan kuesioner PHQ-9 mengidentifikasi 7\% responden 
mengalami gejala depresi ringan serta masing-masing $2 \%$ responden mengalami gejala depresi sedang dan berat selama menjalani isoman.

Situasi isoman yang kurang ideal ini menjadi latar belakang dilaksanakannya TELEKODINA oleh Fakultas Kedokteran Universitas Udayana dan Ikatan Dokter Indonesia Cabang Denpasar. Dari diskusi dengan peserta isoman selama kegiatan tersebut, dapat dirumuskan beberapa informasi yang dirasa penting untuk diketahui peserta isoman. Untuk merangkum informasi-informasi tersebut, maka disusunlah bunga rampai ini untuk mendukung peserta isoman menjalani isolasi mandiri sesuai protokol dalam keadaan yang selalu sehat jasmani maupun rohani. 


\section{LABORATORIUM COVID-19 UNTUK PASIEN YANG MENJALANI ISOLASI MANDIRI}

Ni Kadek Mulyantari, AA Wiradewi Lestari

Saat ini kita sudah memasuki tahun kedua pandemi Coronavirus disease 2019 (COVID-19). Manisfestasi klinis yang dimunculkan oleh infeksi severe acute respiratory syndrome coronavirus 2 (SARS-CoV2) sangat bervariasi, mulai dari tanpa gejala, bergejala ringan, sedang, berat hingga kritis. Pasien tanpa gejala adalah orang yang terinfeksi SARSCoV2 yang dibuktikan dari hasil pemeriksaan swab namun tidak menunjukkan gejala apa pun. Beberapa gejala pada pasien COVID-19 dengan derajat ringan antara lain batuk, pilek, sakit tenggorokan, demam, dan pegal-pegal. Pasien COVID-19 dengan derajat sedang umumnya sudah mengalami pneumonia yang menyebabkan sulit bernapas hingga terasa berat, bahkan sesak. Pasien yang sudah memasuki fase kritis dapat disertai peneumonia berat, sindroma stress pernafasan akut, gagal nafas sampai gagal multi organ. Beberapa bukti juga menunjukan bahwa pasien COVID-19 dapat mengalami keluhan tidak hanya berkaitan dengan fungsi paru-paru dan saluran nafas tapi dapat juga mengenai sistem tubuh yang lain. Sepertiga pasein COVID-19 dapat mengalami keluhan pada saraf seperti hilangnya kemampuan membaui atau anosmia. Beberapa pasien mengalami keluhan pada saluran cerna seperti mual, muntah dan diare. Keluhan lain meskipun tidak umum, dapat bermanifestasi pada kulit seperti munculnya rash pada kulit, gatalgatal, bercak-bercak perdarahan dan lain-lain. Pasien dengan gejala sedang, berat dan kritis sebaiknya melakukan perawatan di rumah sakit. Pasien tanpa gejala atau gelaja ringan masih diperkenankan untuk 
melakukan isolasi mandiri baik di tempat isolasi terpusat maupun isolasi di rumah.

Pemeriksaan laboratorium untuk pasien COVID-19 tanpa gejala dan gejala ringan umumnya tidak komplek. Penegakan diagnosis pasti tetap melalui tahapan anamnesis, pemeriksaan fisik dan pemeriksaan penunjang seperti pemeriksaan laboratorium. Pemeriksaan laboratorium dapat berupa laboratorium non spesifik COVID-19 dan laboratorium spesifik COVID-19. Pemeriksaan laboratorium non spesifik umumnya dilakukan pada pasien dengan gejala ringan namun hasil anamnesis dan pemeriksaan fisik kurang spesifik menunjang diagnosis COVID-19. Artinya masih ada kemungkinan penyakit lain yang diderita oleh pasien selain COVID-19. Penyakit tersebut antara lain kecurigaan demam berdarah, demam tifoid atau penyakit infeksi lainnya. Evaluasi klinis dan permintaan pemeriksaan laboratorium sebaiknya dilakukan oleh dokter.

Salah satu pemeriksaan laboratorium yang dapat digunakan sebagai skrining awal untuk penunjang diagnosis COVID-19 dan menyingkirkan infeksi yang lain adalah pemeriksaan darah lengkap. Pada hasil pemeriksaan darah lengkap akan menampilkan secara lengkap profil sel-sel darah baik sel darah merah, sel darah putih maupun trombosit. Hasil pemeriksaan darah lengkap pada pasien COVID-19 memang kurang spesifik bila dibandingkan pada kasus demam berdarah yang menampilkan penurunan leukosit dengan jumlah limfosit yang dominan, peningkatan hematokrit dan hemoglobin serta penurunan jumlah trombosit. Hasil darah lengkap pada pasien COVID-19 sangat bervariasi. Sebagian besar pasien COVID-19 dengan gejala ringan masih menunjukkan hasil darah lengkap yang normal, beberapa kasus terjadi penurunan jumlah limfosit, peningkatan jumlah neutrofil, penurunan atau 
peningkatan ringan pada jumlah trombosit. Salah satu parameter hasil darah lengkap yang sering dipakai adalah rasio antara jumlah neutrofil dan limfosit (Neutrophil to lymphocyte ratio (NLR)), rasio antara jumlah trombosit dan limfosit (Platelet to lymphocyte ratio (PLR)). Pada pasien COVID-19 akan terjadi peningkatan NLR dan PLR yang signifikan dibandingkan pasien SARS-CoV2 negatif.

Apabila dari anamnesis dan pemeriksaan fisik pasien menunjukkan gejala khas COVID-19, maka pemeriksaan spesifik untuk COVID-19 dapat dilakukan. Untuk kebutuhan skrining maupun diagnosis dapat menggunakan pemeriksaan Nucleic Acid Amplification Test (NAAT) maupun tes antigen. Pemeriksaan NAAT dapat dilakukan dengan beberapa metode, antara lain dengan Real Time Polymerase Chain Reaction (RT-PCR), tes cepat molekuler (TCM) dan loop-mediated isothermal amplification (LAMP) yang telah disetujui Kementerian Kesehatan. Untuk penegakan diagnosis, pengambilan sampel swab RTPCR dilakukan pada hari ke-1 dan 2. Bila pemeriksaan di hari pertama sudah positif, tidak perlu lagi pemeriksaan di hari kedua. Apabila pemeriksaan di hari pertama negatif, maka diperlukan pemeriksaan di hari berikutnya (hari kedua). Untuk kasus tanpa gejala, gejala ringan yang menjalani isolasi mandiri tidak perlu dilakukan pemeriksaan RT-PCR untuk follow-up. Pemeriksaan follow-up hanya dilakukan pada pasien yang berat dan kritis. Pada kasus terkonfirmasi yang tidak bergejala (asimtomatik), isolasi dilakukan selama sekurang-kurangnya 10 hari sejak pengambilan spesimen diagnosis konfirmasi. Pada kasus terkonfirmasi yang bergejala, isolasi dilakukan selama 10 hari sejak muncul gejala ditambah dengan sekurang-kurangnya 3 hari bebas gejala demam dan gangguan pernapasan. Sehingga, untuk kasus-kasus yang mengalami gejala selama 10 hari atau kurang harus menjalani isolasi 
selama 13 hari. Pada daerah yang tidak terjangkau oleh RT-PCR dapat dilakukan tes antigen. Namun salah satu kelemahan tes antigen adalah bahwa tes ini hanya sensitif di awal infeksi, sehingga akan memungkinkan terjadi hasil RT-PCR masih positif tapi hasil tes antigen sudah negatif.

Adapun perbedaan metode RT-PCR dan tes antigen dirangkum pada tabel berikut:

Tabel 3.1. Perbedaan RT-PCR dan tes antigen untuk kebutuhan diagnosis dan skrining infeksi SARS-CoV2.

\begin{tabular}{|c|c|c|c|}
\hline No & Keterangan & RT-PCR & Tes antigen \\
\hline 1 & Deteksi test & $\begin{array}{l}\text { Materi genetik virus } \\
\text { (RNA virus) }\end{array}$ & $\begin{array}{l}\text { Komponen virus (protein } \\
\text { virus) }\end{array}$ \\
\hline 2 & $\begin{array}{l}\text { Waktu yang } \\
\text { tepat untuk } \\
\text { pengambilan } \\
\text { spesimen }\end{array}$ & $\begin{array}{l}\text { 2-3 hari sebelum muncul } \\
\text { gejala sampai rerata 14- } \\
21 \text { hari sejak munculnya } \\
\text { gejala } \\
\text { Atau minimal } 3 \text { hari sejak } \\
\text { kontak erat terakhir bila } \\
\text { tanpa gejala }\end{array}$ & $\begin{array}{l}2 \text { hari sebelum } \\
\text { munculnya gejala } \\
\text { sampai 5-7 sejak } \\
\text { munculnya gejala }\end{array}$ \\
\hline 3 & $\begin{array}{l}\text { Jenis } \\
\text { Spesimen }\end{array}$ & $\begin{array}{l}\text { Swab saluran nafas } \\
\text { (paling sering swab } \\
\text { nasofaring atau } \\
\text { orofaring) }\end{array}$ & $\begin{array}{l}\text { Swab saluran nafas } \\
\text { (paling sering swab } \\
\text { nasofaring atau } \\
\text { orofaring) }\end{array}$ \\
\hline 4 & $\begin{array}{l}\text { Penyimpanan } \\
\text { dan stabilias } \\
\text { spesimen }\end{array}$ & $\begin{array}{l}\text { Pada suhu } 2-8^{\circ} \mathrm{C}(\leq 5 \\
\text { hari) } \\
\text { Pada suhu }-70^{\circ} \mathrm{C}(>5 \\
\text { hari) }\end{array}$ & $\begin{array}{l}\text { Spesimen tidak bisa } \\
\text { disimpan, pemeriksaan } \\
\text { dalam waktu tidak lebih } \\
\text { dari } 2 \text { jam setelah } \\
\text { pengambilan spesimen }\end{array}$ \\
\hline 5 & $\begin{array}{l}\text { Lama Waktu } \\
\text { pemeriksaan }\end{array}$ & Rerata 6 jam & 10-30 menit \\
\hline 6 & Kelebihan & $\begin{array}{l}\text { - Mendeteksi langsung } \\
\text { materi genetik virus } \\
\text { - Sampai saat ini } \\
\text { digunakan sebagai } \\
\text { pemeriksaan rujukan }\end{array}$ & $\begin{array}{l}\text { - Mendeteksi langsung } \\
\text { komponen virus } \\
\text { - Baik untuk deteksi } \\
\text { fase akut (awal } \\
\text { penyakit) } \\
\end{array}$ \\
\hline
\end{tabular}




\begin{tabular}{|c|c|c|c|}
\hline & & $\begin{array}{l}\text { untuk deteksi SARS- } \\
\text { CoV2 }\end{array}$ & $\begin{array}{l}\text { - Tidak memerlukan } \\
\text { ketrampilan petugas } \\
\text { secara khusus dalam } \\
\text { mengerjakan } \\
\text { pemeriksaan } \\
\text { - Spesimen bisa } \\
\text { dikerjakan satu } \\
\text { persatu }\end{array}$ \\
\hline 7 & Kekurangan & $\begin{array}{l}\text { - Tidak efektif dan tidak } \\
\text { efisien mengerjakan } \\
\text { sampel satu per satu } \\
\text { (menunggu jumlah } \\
\text { sampel cukup). } \\
\text { - Ketrampilan petugas } \\
\text { dalam mengambil } \\
\text { spesimen dapat } \\
\text { mempengaruhi hasil } \\
\text { - Membutuhkan tenaga } \\
\text { khusus dan sudah } \\
\text { terlatih } \\
\text { - Membutuhkan alat } \\
\text { khusus dan sarana lab } \\
\text { yang standar untuk } \\
\text { mengerjakan test } \\
\text { - Hasil RT-PCR masih } \\
\text { bisa positif meskipun } \\
\text { virus sudah tidak } \\
\text { hidup atau sudah tidak } \\
\text { menularkan ke orang } \\
\text { lain }\end{array}$ & $\begin{array}{l}\text { - Hanya dapat } \\
\text { mendeteksi pada fase } \\
\text { akut } \\
\text { - pada fase non akut } \\
\text { (hasil RT-PCR masih } \\
\text { positif, hasil rapid } \\
\text { antigen sudah negatif) } \\
\text { - Ketrampilan petugas } \\
\text { dalam mengambil } \\
\text { spesimen dapat } \\
\text { mempengaruhi hasil } \\
\text { - Memerlukan perhatian } \\
\text { khusus terhadap } \\
\text { sensitivitas tes yang } \\
\text { bervariasi } \\
\text { - Uji validasi masih } \\
\text { terbatas sehingga } \\
\text { belum dapat } \\
\text { menggantikan RT- } \\
\text { PCR }\end{array}$ \\
\hline
\end{tabular}




\section{DAFTAR PUSTAKA}

Centers for Disease Control and Prevention. 2021. Overview of Testing for SARS-CoV-2 (COVID-19). Online. Diakses melalui https://www.cdc.gov/coronavirus/2019-ncov/hcp/testingoverview.html pada tanggal 3 Agustus 2021.

Kementerian Kesehatan Republik Indonesia. 2021. Buku saku protokol tata laksana COVID-19. Online. Diakses melalui https://promkes.kemkes.go.id/buku-saku-protokol-tata-laksanaCOVID-19 pada tanggal 3 Agustus 2021.

Kementerian Kesehatan Republik Indonesia. 2021. Panduan Pelaksanaan Pemeriksaan, Pelacakan, Karantina, dan Isolasi Dalam Rangka Percepatan Pencegahan dan Pengendalian Corona Virus Disease 2019 (COVID-19). Jakarta: Kementerian Kesehatan Republik Indonesia.

Seyit, M., Avci, E., Nar, R., Senol, H., Yilmaz, A., Ozen, M., Oskay, A. and Aybek, H., 2021. Neutrophil to lymphocyte ratio, lymphocyte to monocyte ratio and platelet to lymphocyte ratio to predict the severity of COVID-19. The American journal of emergency medicine, 40, pp.110-114.

Tsai, P.H., Lai, W.Y., Lin, Y.Y., Luo, Y.H., Lin, Y.T., Chen, H.K., Chen, Y.M., Lai, Y.C., Kuo, L.C., Chen, S.D. and Chang, K.J., 2021. Clinical manifestation and disease progression in COVID-19 infection. Journal of the Chinese Medical Association, 84(1), pp.38. 


\section{PERSYARATAN ISOLASI MANDIRI COVID-19, KAPAN DIMULAI DAN DIAKHIRI}

I Made Susila Utama, I Ketut Agus Somia, Cokorda Wahyu

Purnamasidhi

\section{PENGENALAN PADA COVID-19}

Corona Virus Disease atau COVID-19 didefinisikan sebagai penyakit yang disebabkan oleh novel coronavirus yang disebut severe acute respiratory syndrome coronavirus 2 (SARS-CoV-2) yang pertama kali diidentifikasi di tengah kejadian luar biasa kasus penyakit respiratori di Kota Wuhan, Provinsi Hubei, Cina. Pertama kali dilaporkan oleh World Health Organization (WHO) pada 31 Desember 2019. Pada 30 Januari 2020, Who menyatakan COVID-19 sebagai kegawatdaruratan global. WHO mendeklarasikan COVID-19 sebagai pandemi global pada 11 Maret 2020. Manifestasi klinis dari SARS-CoV-2 lebih bervariasi dibandingkan dengan influenza dan berbeda-beda pada tiap wilayah. Gejala dapat berupa asimtomatis/gejala ringan hingga gejala berat/kematian yang berkembang 2 hari hingga 2 minggu setelah terpapar virus. Gejala ringan termasuk suhu diatas $37,5^{\circ} \mathrm{C}$ dengan batuk kering yang dapat berkembang menjadi gejala sedang. Gejala berat dapat berupa sesak napas, dispnea, dan takipnea

Penyebaran COVID-19 sangatlah cepat hingga dapat menjadi pandemi di berbagai dunia saat ini. Virus COVID-19 dapat menyebar bila seseroang mengalami kontak langsung dengan seseorang yang terkonfirmasi COVID-19 ataupun meyentuh permukaan benda yang terkontaminasi. Melalui transmisi udara dan droplet mengakibatkan virus ini dengan mudahnya dapat menyebar dan memyebabkan kontaminasi. 
Prevalensi COVID-19 meningkat secara cepat di seluruh dunia dalam satu bulan setelah teridentifikasi telah menyebar ke seluruh Cina, Italia, Amerika Serikat, dan Jerman. Kasus COVID-19 di Indonesia pertama kali dikonfirmasi pada 2 Maret 2020. Angka kasus COVID-19 secara global hingga saat ini telah mencapai 199.099.061 kasus dan 3.496.700 kasus di Indonesia. COVID-19 secara statistik lebih rentan terinfeksi pada lakilaki pada usia produktif $(56,5 \%)$ dan mortalitas tertinggi pada pasien lanjut usia $>60$ tahun $(43,6 \%)$.

\section{PERSYARATAN ISOLASI MANDIRI COVID-19, KAPAN DIMULAI DAN DIAKHIRI}

Isolasi merupakan pemisahan pasien yang masih suspek atau terkonfirmasi mengalami infeksi COVID-19. Pasien yang boleh melakukan isolasi mandiri hanyalah pasien TANPA GEJALA atau GEJALA RINGAN. Isolasi mandiri dilakukan selama 10 hari sejak pengambilan spesimen diagnosis positif COVID-19 dan dilakukan secepat mungkin dari munculnya gejala pertama kali.

Selama isolasi mandiri, pasien harus tinggal di rumah dan:

- Selalu menggunakan masker dan menjaga jarak apabila keluar kamar dan saat berinteraksi dengan anggota keluarga

- Cuci tangan menggunakan air mengalir dan sabun atau hand sanitizer sesering mungkin

- Berjemur dengan matahari sekitar 10-15 menit sebelum jam 9 atau setelah jam 3 setiap hari

- Segera cuci pakaian yang dipakai, apabila ingin disimpan masukkan ke dalam kantung plastik 
- Buka jendela kamar secara berkala dan bersihkan kamar secara berkala

Apabila tidak tinggal sendirian, pasien COVID-19 harus tidur dan beraktivitas secara terpisah dari orang lain. Apabila tersedia, pasien COVID-19 dapat menggunakan kamar mandi terpisah. Selama isolasi mandiri, pasien dapat mengonsumsi:

- Vitamin C seperti Vitacimin C, Enerviorn-C Multivitamin, dan sebagainya (apabila memungkinkan multivitamin $\mathrm{C}, \mathrm{B}, \mathrm{E}$, dan Zink) dosis 25mg pada anak umur 4-8 tahun, 45mg anak umur 9-13 tahun dan 90mg untuk dewasa

- Vitamin D seperti Blackmores Vitamin D3 1000 IU, L-VIT D3 1000IU dengan dosis 1 kali sehari/ 1000IU per hari

- Antioksidan yang dapat sering kita temui pada sayur bayam, berbagai macam buah beri dan buah anggur.

- Fitofarmaka (obat herbal) yang terdaftar di BPOM

- Obat komorbid (penyakit penyerta) atau komplikasi yang memang sedang dikonsumsi

Pada pasien yang menunjukkan gejala ringan dapat mengonsumsi obat-obatan tambahan yang dapat ditemui pada apotek terdekat sebagai berikut:

- Faviripavir 1600 mg/12 jam pada hari ke-1 dan 600 mg/12 jam pada hari ke 2-5)

- Obat-obatan simtomatis seperti parasetamol apabila demam

Apabila mengonsumsi obat anti-hipertensi golongan ACE-inhibitor seperti captopril dan Angiotensin Receptor Blocker (ARB) seperti candesartan, pasien perlu berkonsultasi dengan dokter spesialis penyakit 
dalam atau spesialis jantung. Pasien akan secara berkala dipantau oleh petugas puskesmas dan dapat kontrol setelah 10 hari karantina untuk pemantauan klinis. Pasien dapat dinyatakan selesai isolasi mandiri apabila:

- Setelah 10 hari sejak pengambilan diagnosis konfirmasi

- Apabila pasien menunjukkan gejala, isolasi baru dapat selesai 10 hari ditambah 3 minimal 3 hari setelah tidak menunjukkan gejala demam dan gangguan pernapasan (batuk \& pilek). 


\section{DAFTAR PUSTAKA}

Gorbalenya, A., Baker, S., Baric, R., de Groot, R., Drosten, C., Gulyaeva, A., Haagmans, B., Lauber, C., Leontovich, A., Neuman, B., Penzar, D., Perlman, S., Poon, L., Samborskiy, D., Sidorov, I., Sola, I. and Ziebuhr, J., 2020. Severe acute respiratory syndrome-related coronavirus: The species and its viruses - a statement of the Coronavirus Study Group. BioRxiv.

Hashmi, H. and Asif, H., 2020. Early Detection and Assessment of COVID-19. Frontiers in Medicine, 7.

Hikmawati, I. and Setiyabudi, R., 2021. Epidemiology of COVID-19 in Indonesia: common source and propagated source as a cause for outbreaks. The Journal of Infection in Developing Countries, 15(05), pp.646-652.

Perhimpunan Dokter Paru Indonesia (PDPI), Perhimpunan Dokter Spesialis Kardiovaskuler Indonesia (PERKI), Perhimpunan Dokter Spesialis Penyakit Dalam Indonesia (PAPDI), Perhimpunan Dokter Anestesiologi dan Terapi Intensif Indonesia (PERDATIN), dan Ikatan Dokter Anak Indonesia (IDAI). 2020. Pedoman Tatalaksana COVID-19 Edisi ke-3. Jakarta: Perhimpunan Dokter Paru Indonesia (PDPI), Perhimpunan Dokter Spesialis Kardiovaskuler Indonesia (PERKI), Perhimpunan Dokter Spesialis Penyakit Dalam Indonesia (PAPDI), Perhimpunan Dokter Anestesiologi dan Terapi Intensif Indonesia (PERDATIN), dan Ikatan Dokter Anak Indonesia (IDAI) 


\title{
SARANA DAN PRASARANA ISOLASI MANDIRI
}

\author{
I Made Dwi Ariawan, Anak Agung Sagung Sawitri
}

Isolasi mandiri (ISOMAN) adalah suatu upaya memisahkan atau membatasi pergerakan orang yang sudah sakit sehingga tidak berinteraksi dengan keluarga dan masyarakat di sekitarnya. Lama isolasi setidaknya 10 hari sejak pengambilan sampel usap tenggorok/hidung dan ditambah 3 hari bebas gejala demam/gangguan pernafasan untuk pasien konfirmasi dengan gejala ringan dan sedang. Tempat isolasi mandiri bisa di rumah pribadi ataupun tempat yang disediakan oleh pihak lain, rumah atau tempat tidak perlu mewah yang penting memenuhi syarat-syarat kesehatan.

\section{SYARAT-SYARAT RUMAH YANG BISA DIGUNAKAN UNTUK ISOLASI MANDIRI}

- Tersedia akses jalan untuk kendaraan

- Dinding ruangan berbahan permanen atau semi-permanen

- Lantai sebaiknya kedap air dan tidak boleh diberi karpet/perlak/permadani

- Sirkulasi udara memadai, artinya tersedia jendela atau lubang angin dalam jumlah yang cukup dan dapat mengalirkan udara keluar masuk ruangan. Jika tidak ada jendela/lubang angin, dapat dipertimbangkan menggunakan exhauster

- Tersedia sarana mandi, cuci dan kakus dengan saluran pembuangan air limbah. Sebaiknya digunakan terpisah dengan anggota keluarga yang lain, jika tidak memungkinkan, bisa diatur jadwal penggunaannya dimana yang positif diberikan giliran 
paling akhir atau diberikan waktu jeda yang cukup antara anggota keluarga.

- Sedapat mungkin pasien isoman sendiri di rumah atau memiliki kamar/ruangan yang benar-benar terpisah dengan anggota keluarga yang lain. Jika masih ada anggota keluarga yang lain, aturlah perabot di rumah sehingga memungkinkan alur satu arah atau lalu lalang di dalam rumah, untuk menghindari pertemuan atau interaksi langsung antara anggota keluarga yang positif dengan yang masih negatif

- Siapkan area untuk menjemur pakaian dan fasilitas untuk mencuci pakaian

- Upayakan ada dapur yang siap untuk digunakan

- Tersedia aliran listrik dan air bersih yang memadai

- Tersedia tempat pembuangan sampah sementara yang tertutup

Di dalam rumah yang digunakan untuk isoman, perlu dilengkapi dengan sarana dan prasarana untuk membantu pasien isoman dan atau anggota keluarga lainnya agar bisa menerapkan upaya pencegahan penularan COVID-19 secara maksimal.

\section{SARANA DAN PRASARANA YANG DIPERLUKAN}

- Tersedia tempat tidur dan kasur yang layak

- Ada tempat cuci tangan dengan fasilitas air mengalir dan dilengkapi sabun

- Tersedia media informasi atau pedoman terkait cara pencegahan penularan yang benar, gejala klinis perberatan penyakit dan cara mengetahuinya, nomor kontak yang bisa dihubungi ataupun informasi lain yang sesuai karakteristik pasien, misalnya ibu 
hamil bisa ditambahkan media KIE tentang ANC dan makanan sehat.

- Jika memungkinkan dapat disediakan alat dukung seperti termometer, pulseoxymetri atau oxymetri

- Tempat sampah bahan infeksius (ditandai dengan plastik kuning)

- Kebutuhan sehari-hari antara lain: air minum, bahan makanan pokok, peralatan kebersihan ruangan (sapu, pembersih meja, pengepel dII)

- Alat-alat pencegahan penularan infeksi COVID-19 seperti masker dan hand-sanitizer wajib disediakan dalam jumlah yang cukup. Idealnya masker yang disediakan adalah adalah masker medis/masker bedah yang tetap digunakan walaupun di dalam kamar.

- Usahakan ada telpon yang bisa digunakan untuk komunikasi antara pasien isoman dan anggota keluarga ataupun dengan pihak lainnya.

Jika ada anggota keluarga yang menjalani isoman dan kondisi rumah memang tidak memungkinkan mencegah interaksi dengan pasien, maka seluruh anggota rumah tangga dianggap menjalani isolasi mandiri. Karena itu, dibutuhkan peran keluarga yang lain, tetangga ataupun pemangku kepentingan (misalnya satgas COVID, kepala lingkungan ataupun puskesmas) untuk menjaga ketersediaan sarana dan prasarana penghuni rumah selama menjalani isoman.

\section{PERAN DARI KELUARGA YANG LAIN, TETANGGA ATAUPUN PEMANGKU KEPENTINGAN}

- Memantau ketersediaan logistik dan kebutuhan sehari-hari keluarga 
- Membantu menjembatani kebutuhan keluarga dengan pihak lain, misal dalam hal rujukan kasus

- Membantu melakukan pengawasan terkait kepatuhan melakukan isoman dari pasien dan anggota keluarga

\section{APAKAH YANG TIDAK BOLEH DILAKUKAN PASIEN DAN ANGGOTA KELUARGA SAAT MENJALANI ISOMAN?}

- Tidak boleh keluar kamar atau ruangan jika tidak perlu. Keluar kamar diperbolehkan HANYA untuk mencuci dan menjemur pakaian, ber-olah raga di bawah sinar matahari \pm 30 menit s/d 60 menit sebelum jam 10.00 wita. Dengan catatan tetap menggunakan masker secara benar dan menjaga jarak 1.5 meter.

- Tidak boleh menerima tamu dari luar, maupun bertemu dan beraktivitas bersama anggota keluarga se rumah

- Tidak boleh menggunakan ataupun menyimpan barang pribadi bersama-sama milik penghuni lain

\section{APAKAH YANG WAJIB DILAKUKAN PASIEN DAN ANGGOTA KELUARGA SAAT MENJALANI ISOMAN?}

- Tetap di kamar namun harus bisa dihubungi ataupun melakukan komunikasi dengan anggota keluarga

- Melakukan upaya higine dan sanitasi per-orangan maupun lingkungan. Contohnya, sesering mungkin cuci tangan dengan sabun dan air mengalir atau dengan hand-sanitizer pada hampir semua aktivitas; ataupun menjaga kebersihan lingkungan sekitar. 
- Menggunakan masker. Masker diganti setiap 4 jam, dan masker yang sudah bekas harus dibuang ke tempat sampah medis dalam kondisi terlipat ke arah dalam. Jika keluar kamar, sebaiknya menggunakan masker medis yang dirangkap masker kain. Selain itu, jika ada anggota keluarga yang berada di dalam rumah maka semua wajib mengenakan masker secara benar (menutup hidung, mulut dan dagu) serta digunakan secara konsisten (tetap digunakan selama berada di dalam rumah tempat isolasi).

- Melaporkan secara rutin kondisi kesehatannya setiap hari kepada keluarga ataupun petugas

- Mencuci pakaian, sprei ataupun desinfeksi area yang sering disentuh

- Mengonsumsi vitamin dan makanan sehat dan seimbang

- Melakukan jaga jarak 1.5 meter jika keluar kamar atau ruangan 


\section{DAFTAR PUSTAKA}

CDC. 2019. Interim Guidance for Implementing Home Care of People Not Requiring Hospitalization for Coronavirus Disease 2019 (COVID19). Diakses melalui https://www.cdc.gov/coronavirus/2019ncov/hcp/guidance-home-care.html

CDC. 2019. Ending Home Isolation for Persons with COVID-19 Not in Healthcare Settings. Diakses melalui: https://www.cdc.gov/coronavirus/2019-ncov/hcp/disposition-inhome-patients.html

CDC. 2019. Caring for Someone Sick at Home. Diakses melalui: https://www.cdc.gov/coronavirus/2019-ncov/if-you-are-sick/carefor-someone.html

NICD.2020. GUIDELINES FOR QUARANTINE AND ISOLATION IN RELATION TO COVID-19 EXPOSURE AND INFECTION. Diakses melalui: https://www.nicd.ac.za/wpcontent/uploads/2020/05/Guidelines-for-Quarantine-and-Isolationin-relation-to-COVID-19.pdf 


\section{GEJALA DAN TANDA UMUM YANG HARUS DIPERHATIKAN SELAMA ISOLASI MANDIRI}

Pande Made Andikayasa, Gede Oky Aryanthana, Ni Luh Putu Eka Arisanti, I Gede Ketut Sajinadiyasa

Isolasi mandiri adalah salah satu bentuk peran serta masyarakat dalam menghadapi pandemi, saat isolasi mandiri pasien COVID-19 diharapkan bisa melaksanakan perilaku hidup bersih dan sehat, serta menerapkan protokol kesehatan sehingga segera sehat kembali tanpa menularkan virus ke keluarga atau masyarakat sekitar. Saat isolasi mandiri terdapat dua hal yang harus menjadi perhatian yaitu mencegah penularan virus ke anggota keluarga dengan tetap melakukan protokol kesehatan walaupun hanya berada di rumah dan juga melakukan pemantauan terhadap kondisi kesehatannya agar tidak terjadi keterlambatan dalam mendapatkan penanganan medis yang sesuai dengan kondisinya. Saat melakukan isolasi, pasien harus selalu memantau kondisinya dan melaporkannya kepada tenaga kesehatan. Buatlah sebuah catatan tentang perjalanan gejala dan kondisi tubuh saat isolasi mandiri, sehingga memudahkan dalam pemantauan. Saat melakukan isolasi mandiri penting untuk menyiapkan alat pengukur suhu yaitu termometer dan alat oxymeter untuk mengukur kadar oksigen. Adapun tanda dan gejala yang harus diperhatikan yaitu :

- $\quad$ Batuk yang memberat

Batuk merupakan gejala yang umum didapatkan pada pasien COVID-19. Bila batuk bertambah sering dan disertai dengan dahak kuning atau darah, hubungi tenaga kesehatan untuk mendapatkan saran lebih lanjut. 
- Napas semakin pendek, sesak napas, atau mudah lelah saat aktifitas ringan

Manusia bernapas normalnya 12-18 kali permenit, waspadalah jika anda bernapas lebih dari 20 kali permenit. Cara menghitungnya yaitu dengan memperhatikan gerak dada saat bernapas didepan kaca selama satu menit. Jika gerak napas cepat, mudah lelah saat aktifitas ringan, apalagi disertai penurunan saturasi oksigen sebaiknya dirawat di rumah sakit atau fasilitas lain yang diawasi oleh tenaga kesehatan.

- Nyeri dada

Sakit pada dada, terutama pada dada kiri apalagi disertai dengan sakit yang menjalar sampai ke dagu atau tangan kiri dan disertai keringat dingin harus diwaspadai dan segera dilaporkan ke tenaga kesehatan

- Demam terus menerus

Demam adalah respon normal tubuh terhadap infeksi, dinyatakan sebagai demam apabila suhu tubuh yang diperiksa dengan termometer menunjukkan nilai $\geq 38^{\circ} \mathrm{C}$. Demam dapat diturunkan dengan melakukan kompres hangat dan atau meminum obat penurun panas, tetapi jika demam berlangsung terus menerus dan lebih dari 7 hari padahal sudah mengkonsumsi obat penurun panas maka segera hubungi dan diskusikan dengan tenaga kesehatan.

- Muntah terus menerus

Muntah yang terjadi terus menerus akan menyebabkan asupan cairan dan makanan terganggu sehingga pasien menjadi lemas.

- Diare terus menerus 
Diare atau buang air besar dengan konsistensi cair terus menerus juga dapat menyebabkan terjadinya kekurangan cairan dan elektrolit sehingga perlu penanganan lebih lanjut. Tanda kekurangan cairan yaitu muncul rasa haus yang berlebih, mulut kering, frekuensi buang air kecil yang menurun, warna cairan kencing yang menjadi lebih pekat

- Gangguan Kesadaran

Kontak yang menurun, ditandai dengan sulit untuk dibangunkan, tidak nyambung saat diajak berkomunikasi merupakan salah satu gejala yang harus diwaspai, segera ke rumah sakit atau hubungi fasilitas kesehatan terdekat bila hal ini ditemukan pada pasien yang melakukan isolasi mandiri

Tabel 6.1. Catatan Harian Isolasi Mandiri

\begin{tabular}{|c|c|c|c|c|c|c|c|c|}
\hline & \multicolumn{2}{|c|}{ Hari 1} & \multicolumn{2}{|c|}{ Hari 2} & \multicolumn{2}{|c|}{ Hari 3} & \multicolumn{2}{|c|}{ Hari... } \\
\hline Keluhan & Pagi & Sore & Pagi & Sore & Pagi & Sore & Pagi & Sore \\
\hline Sesak & & & & & & & & \\
\hline Batuk & & & & & & & & \\
\hline Muntah & & & & & & & & \\
\hline diare & & & & & & & & \\
\hline Nyeri dad & & & & & & & & \\
\hline Keluhan I & & & & & & & & \\
\hline $\begin{array}{l}\text { Laju nar } \\
\text { permenit }\end{array}$ & & & & & & & & \\
\hline $\begin{array}{l}\text { Frekuensi } \\
\text { nadi } \\
\text { permenit }\end{array}$ & & & & & & & & \\
\hline Suhu & & & & & & & & \\
\hline $\begin{array}{l}\text { Saturasi } \\
\text { oksigen }\end{array}$ & & & & & & & & \\
\hline
\end{tabular}

Penting untuk melakukan pemantauan terhadap kondisi tubuh saat melakukan isolasi mandiri, Buatlah sebuah catatan harian tentang 
keluhan dan tanda klinis yang didapatkan saat melakukan isolasi mandiri. Catatan dapat diisi dua kali sehari saat pagi dan sore pada jam yang sama, atau bila terjadi kondisi yang memerlukan perhatian lebih. Catatan ini akan membantu pasien dan tenaga kesehatan dalam memutuskan apakah pasien dapat melanjutkan isolasi mandiri, memindahkan pasien ke tempat isolasi lain dengan pengawasan tenaga kesehatan misalnya rumah sakit dan juga memutuskan kapan pasien selesai menjalani isolasi mandiri.

Tabel 6.2. Panduan berdasarkan nilai saturasi oksigen

\begin{tabular}{|l|l|}
\hline Nilai saturasi Oksigen & Hal yang harus dilakukan \\
\hline $95 \%$ sampai dengan 100\% & $\begin{array}{l}\text { Tetap diam dirumah dan lanjutkan } \\
\text { untuk mengecek saturasi oksigen } \\
\text { secara teratur }\end{array}$ \\
\hline 93 atau 94\% & $\begin{array}{l}\text { Ulangi cek saturasi oksigen dalam } \\
1 \text { jam, jika masih 93 atau } 94 \\
\text { hubungi tenaga kesehatan untuk } \\
\text { saran lebih lanjut }\end{array}$ \\
\hline $92 \%$ atau kurang & $\begin{array}{l}\text { Segera cek ulang saturasi } \\
\text { oksigen, jika masih tetap 92\% } \\
\text { atau kurang, segera ke Unit } \\
\text { Gawat Darurat (UGD) atau } \\
\text { hubungi fasilitas kesehatan } \\
\text { terdekat }\end{array}$ \\
\hline
\end{tabular}

Saturasi oksigen adalah nilai kelarutan oksigen dalam darah yang juga menunjukkan apakah kebutuhan oksigen terpenuhi atau tidak, dan saturasi oksigen dapat diukur dengan alat oxymeter. Infeksi paru oleh COVID-19 merupakan salah satu bentuk infeksi yang umum terjadi pada pasien dengan COVID-19 sehingga paru-paru tidak dapat lagi memenuhi kebutuhan oksigen tubuh. Saat kondisi fasilitas kesehatan overload dan 
tidak mampu untuk merawat semua pasien dengan infeksi COVID-19 maka pemantauan terhadap saturasi oksigen penting untuk dilakukan terutama pada pasien terkonfirmasi COVID-19 yang menunjukkan gejala pernapasan seperti batuk, dada berat, dan napas cepat yang menjalani isolasi mandiri. Gunakan panduan berdasarkan nilai saturasi oksigen untuk menetukan hal yang harus dilakukan saat melakukan isolasi mandiri. Saat saturasi oksigen $92 \%$ atau kurang maka isolasi mandiri sebaiknya dihentikan dan pasien menjalani isolasi dan perawatan di rumah sakit atau fasilitas lain yang diawasi langsung oleh tenaga kesehatan.

Mengakhiri pandemi COVID-19 dan memutus penularan virus COVID-19 merupakan tanggungjawab setiap orang, mari lindungi diri, keluarga dan lingkungan dengan melakukan isolasi mandiri saat memiliki gejala COVID-19, kontak dengan pasien COVID-19 dan saat terkonfirmasi COVID-19 secara bertanggungjawab dengan tetap melakukan protokol kesehatan dan pemantauan berkala.

P2PTM Kemenkes RI. Protokol isolasi mandiri. 2021. Kementerian kesehatan Republik Indonesia 


\section{DAFTAR PUSTAKA}

Direktorat Jenderal Pencegahan dan Pengendalian Penyakit. Buku Saku Pelacakan kontak kasus Covid 19. 2021. Kementerian kesehatan $\mathrm{RI}$

Kementerian kesehatan RI. Pedoman pencegahan dan pengendalian Covid 19. 2020. Kementerian kesehatan RI

NHS. Self-isolation and treating symptoms of coronavirus (COVID19).2021. NHS. United Kingdom 


\section{LATIHAN FISIK SELAMA ISOLASI MANDIRI}

Ari Wibawa

Latihan fisik/olahraga termuat ke dalam salah satu protokol isolasi mandiri oleh Kemenkes. Saat ini belum ada protokol rumah untuk terapi olahraga yang divalidasi, mengingat COVID-19 adalah penyakit dan pengalaman baru di seluruh dunia. Rekomendasi program aktivitas fisik yang layak mempertimbangkan kekhasan pasien, keluarga dan komunitas dianggap paling baik untuk mencapai efek yang diharapkan dari program latihan, dan tetap selalu menghindari proses penularan dengan menjaga protokol kesehatan (Rivas-Estany, Eduardo, 2020). Berikut beberapa latihan yang dilakukan dirumah saat isolasi mandiri.

\section{LATIHAN PERNAPASAN}

Latihan pernapasan penting dilakukan mengingat beberapa, pasien isolasi mandiri kadang mengeluh adanya gejala seperti napas pendek/ sesak, demam, batuk ringan. Latihan ini membantu pola napas yang tepat, mendapatkan efek rilaksasi dan menjaga fungsi paru dan dinding dada lebih optimal. Latihan tersebut terbagi dalam empat gerakan yang mudah untuk diterapkan secara mandiri di rumah, terdiri dari latihan pernapasan dalam (deep breathing) dan menghembuskan dengan bibir mencucu (pursed lip breathing), mobilisasi dinding dada, latihan batuk (huffing, coughing) dan posisi prone (tengkurap).

1. Latihan deep breathing adalah latihan menarik napas dalam, untuk mengembangkan jaringan paru dengan maksimal sehingga dapat menghambat proses restriksi. Berikut ini langkah-langkah latihannya : 
a. Pasien diminta untuk menarik napas dalam, dapat dengan pernapasan dada (thoraco-abdominal breathing, pengembangan maksimal di dada, saat menarik napas) atau pernapasan perut (abdomino-thoracal breathing, pengembangan maksimal di perut, saat menarik napas).

b. Latihan bisa dalam posisi tidur atau duduk sesuai dengan kemampuan, dan dilakukan dengan 3- 5 kali pengulangan.

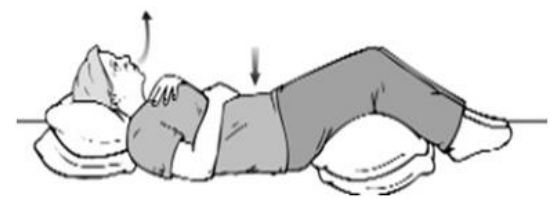

Gambar 7.1. Latihan pada posisi tidur

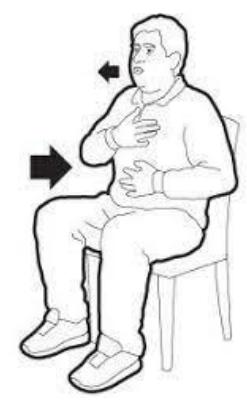

Gambar 7.2. Latihan pada posisi duduk 

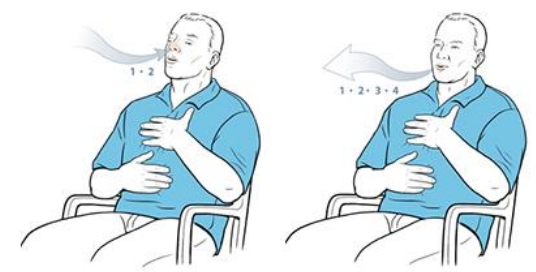

Gambar 7.3. Posisi saat mengeluarkan napas lewat mulut

2. Latihan batuk (huffing, coughing), atau coughing yang secara umum dengan posisi glottis tertutup. Aktivitas ini memerlukan tenaga yang besar dan cukup melelahkan apabila dilakukan berkali-kali. Batuk dengan posisi glottis terbuka (huffing) atau batuk dengan mulut menganga seperti sedang membuat embun saat menghembuskan napas di kaca, merupakan metode batuk yang lebih hemat energi, mampu mendorong dahak ke arah luar saluran napas, dengan berbarengan saat menghembuskan napas/ ekspirasi. Berikut ini langkah-langkah latihannya :

a. Keluarkan udara dari dalam paru-paru dan saluran nafas dengan bernafas pelan, nafas secara perlahan, akhiri dengan mengeluarkan nafas perlahan selama 3-4 detik..

b. Tarik nafas perlahan, tahan nafas 3 detik, untuk mengontrol nafas mempersiapkan melakukakan batuk huff secara efektif.

c. Angkat dagu agak keatas, dan gunakan otot perut dengan lulut terbuka untuk melakukan pengeluaran nafas cepat sebanyak 3 kali, keluarkan dengan bunyi huff, huff, huff. Ini membantu epiglotis terbuka dan mempermudah pengeluaran sekret. 
d. Kontrol nafas, ambil napas pelan 2 kali, setelah itu batukkan

e. Lakukan dengan 2 - 3 kali pengulangan

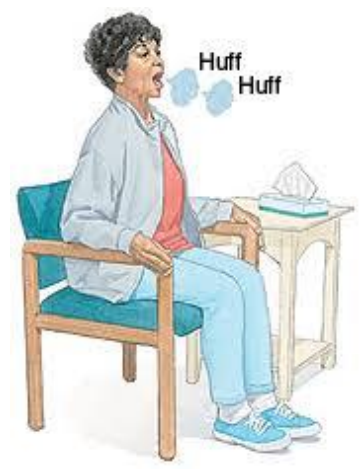

Gambar 7.4. Teknik huffing.

3. Mobilisasi dinding dada. Latihan ini bertujuan untuk melatih dinding dada agar dapat diregangkan melebar dengan tarikan otot-otot yang menempel di sangkar dada, termasuk otot sisi samping, otot depan dan belakang dinding dada. Apabila otototot yang melekat pada dinding dada dapat termobilisasi atau dapat bergerak dengan baik, maka pengembangan dada akan semakin baik sehingga saat proses bernapas akan memudahkan pergerakan paru-paru saat inspirasi (tarik napas) dan ekspirasi (buang napas). Berikut ini langkah-langkah latihannya :

a. Posisi awal pasien duduk di kursi dengan sedikit membungkuk dan kedua lengan menyilang di depan dada. 
b. Pasien diminta menarik napas dan perlahan naikkan kedua lengan hingga posisi tidak menyilang lalu hembuskan napas dan posisi akhir kepala ke atas.

c. Latihan diulangi 3-5 kali sesuai toleransi pasien.

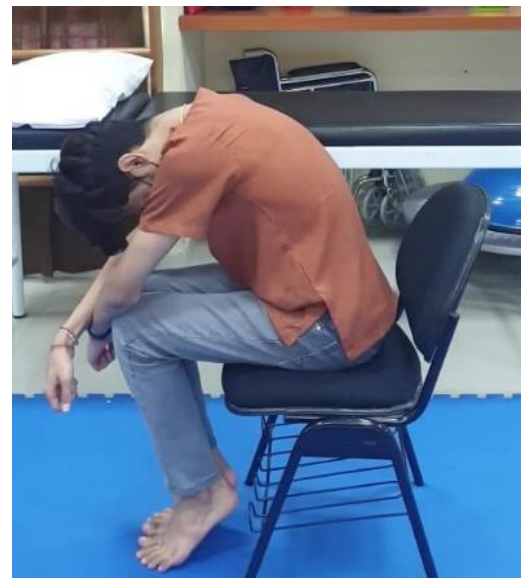

A) Posisi awal

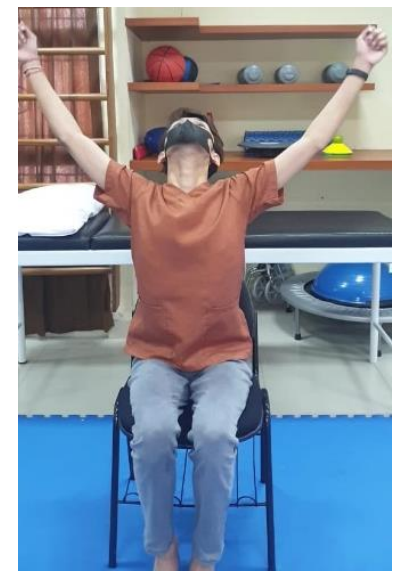

B) Posisi akhir

Gambar 7.5. Mobilisasi dinding dada.

4. Posisi prone (tengkurap). Latihan terakhir dari seluruh rangkaian adalah latihan pernapasan dalam posisi tengkurap (prone) agar terjadi pertukaran gas yang lebih baik. Saat tengkurap, sisi bawah panggul, di bawah perut diganjal bantal, dengan alas tempat tidur yang padat atau cukup keras. Pasien diminta untuk bernapas dalam dengan menggembungkan perut dan ditahan sejenak lalu buang napas. Latihan diulangi 3-5 kali atau sesuai toleransi pasien. 


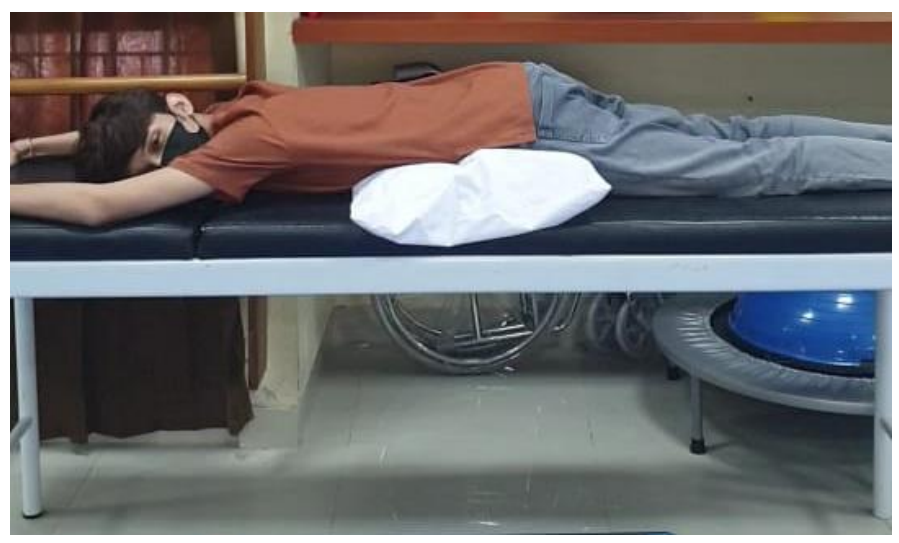

Gambar 7.6. Posisi tengkurap saat latihan nafas

\section{LATIHAN AEROBIK DAN KEKUATAN OTOT}

Pada pasien isolasi mandiri tanpa adanya gejala dan didiagnosis penyakit respirasi, latihan aerobik dan kekuatan otot sangat baik dilakukan. Pedoman aktivitas fisik merekomendasikan 150-300 menit per minggu aktivitas fisik aerobik intensitas sedang dan 2 sesi per minggu latihan kekuatan otot. Latihan bisa dilakukan dalam 2, 5, 10 atau 20 menit. Intensitas sedang yang dimaksud dapat kita ukur dengan cara test bicara (talk test) menunjukkan masih bisa berbicara, namun tidak bisa menyanyi saat sedang berolahraga, selanjutnya dengan target denyut nadi berkisar antara 64-76\% Denyut Nadi Maksimal, dan yang terakhir dengan melihat gejala yang muncul (exertion) adanya keringat, deru napas yang cepat.

Di bawah ini beberapa strategi menjaga aktivitas fisik dan kebugaran yang bisa dilakukan di rumah: 
1. Aktivitas Aerobik

a. Aktivitas dalam ruangan :

i. berjalan cepat di sekitar rumah atau naik turun tangga selama 10-15 menit 2 atau 3 kali sehari.

ii. Menari diiringi musik./ video latihan yang bisa diikuti online

iii. Lompat tali (jika sendi memungkinkan).

iv. Gunakan alat latihan aerobik rumahan seperti sepeda statik, treatmill

b. Aktivitas di luar ruangan (jika memungkinkan)

i. Berjalan atau joging di sekitar lingkungan Anda (hindari ruang yang ramai dan pertahankan jarak fisik 6 kaki yang disarankan antar individu).

ii. Bersepeda.

iii. Lakukan pekerjaan berkebun

iv. Bermain aktif bersama keluarga

c. Pelatihan Kekuatan Otot

i. Melakukan latihan penguatan otot sederhana di sekitar rumah seperti:

ii. Jongkok atau duduk-berdiri dari kursi yang kokoh

iii. Push-up

iv. Lunges atau step-up satu kaki di tangga

Selama berolahraga jika muncul gejala seperti : mual, pusing, sesak napas, nyeri dada silakan dihentikan dan segera menghubungi dokter di fasilitas pelayanan kesehatan terdekat. 


\section{DAFTAR PUSTAKA}

Liz Joy. 2020. Staying Active During COVID-19. Diakses melalui https://www.exerciseismedicine.org/support_page.php/stayingactive-during-COVID-191/ pada 3 Agustus 2021.

Anonim. 2018. Diaphragmatic Breathing. Diakses melalui https://my.clevelandclinic.org/health/articles/9445-diaphragmaticbreathing pada 3 Agustus 2021.

Rivas-Estany, Eduardo. 2020. Re: Home protocol of Physical Therapy for the suspected patient of Corona Virus disease?. Diakses melalui https://www.researchgate.net/post/Home-protocol-of-PhysicalTherapy-for-the-suspected-patient-of-Corona-Virusdisease/5e98823846500b27de468073/citation/download pada 3 Agustus 2021.

Widjanantie, S, C. 2020. Latihan pernapasan pada pasien COVID-19 saat isolasi mandiri di rumah. Diakses melalui https://rsuppersahabatan.co.id/artikel/read/latihan-pernapasanpada-pasien-COVID-19-saat-isolasi-mandiri-di-rumah pada 3 Agustus 2021. 


\section{KESEHATAN PSIKOLOGIS DALAM PANDEMI}

Ni Made Swasti Wulanyani, I Gusti Ayu Diah Fridari, Ni Made Ari Wilani, Putu Nugrahaeni Widiasavitri, Komang Rahayu Indrawati

Pandemi COVID-19 memberikan dampak terhadap pola kehidupan manusia, khususnya masyarakat yang sedang menjalani proses Isolasi Mandiri (Isoman). Perubahan pola kehidupan manusia yang disertai dengan kondisi sakit fisik yang dialami berpotensi memengaruhi kondisi kesehatan mentalnya. Perasaan tidak nyaman yang dirasakan biasanya adalah kecewa, gelisah, takut, kurang bersemangat, burnout, atau merasa bersalah. Kondisi psikologis ini akan menghambat efektifitas pengobatan dan pemulihan karena pembentukan imunitas juga menjadi terganggu. Untuk mendapatkan kesejahteraan psikologis maka harus berlatih untuk IKHLAS menerima kondisi, BERSYUKUR pada kondisi positif yang masih dimiliki, POSITIF (berpikir dari sudut pandang yang lebih nyaman dan bertindak posititf), PASRAH setelah berupaya, dan YAKIN akan sembuh.

Adapun beberapa teknik yang dapat diterapkan adalah:

1. Teknik Stabilisasi emosi

2. Teknik Mindfulness

3. Teknik Kebersyukuran (Gratitude)

4. Teknik Menggambar Bebas

5. Resiliensi dan Kelincahan 
Selain menerapkan teknik-teknik yang dituliskan, masyarakat yang sedang menjalankan isolasi mandiri tetap harus melakukan:

1. Menjaga komunikasi dengan keluarga, teman, atau sahabat (voice call/video call)

2. Mengomunikasikan kondisi kesehatan kepada dokter yang mendampingi proses isolasi mandiri.

3. Mencari informasi dari lembaga yang kredibel/dapat dipertanggungjawabkan.

\section{TEKNIK STABILISASI EMOSI}

Teknik ini bisa dilakukan kapan dan di mana saja untuk membantu mendapatkan rasa aman dan tenang serta menumbuhkan ketahanan dalam menghilangkan perasaan mengganggu yang muncul. Teknik ini diibaratkan sebagai pertolongan pertama, sebelum Anda melanjutkan dengan kegiatan lain yang dibutuhkan.

\section{Langkah-langkah Butterfly Hug}

1. Duduklah dengan posisi nyaman, kemudian pejamkan mata.

2. Fokus pada nafas yang keluar dan masuk. Anda dapat menarik napas melalui hidung, tahan selama sekitar 3 detik dan hembuskan melalui hidung secara perlahan selama 3 detik. Dalam hal ini, yang mengembang dan mengempis adalah perut. Atau, Anda dapat menarik napas selama 4 detik melalui hidung, tahan selama 4 detik, dan kemudian hembuskan melalui mulut selama 4 detik. Lakukan sampai merasa lebih nyaman.

3. Dapat dilanjutkan dengan melakukan gerakan butterfly hug yang dikembangkan dikembangkan oleh Lucina Artigas sejak 
1998, caranya: Silangkan kedua lengan dan letakkan di depan dada, sehingga menyerupai kupu-kupu. Anda juga bisa mengaitkan kedua ibu jari Anda. Bagi sebagian orang, hal tersebut terasa lebih nyaman.

4. Tepuk satu tangan secara perlahan dan bergantian.

5. Hentikan saat Anda sudah merasa tenang,
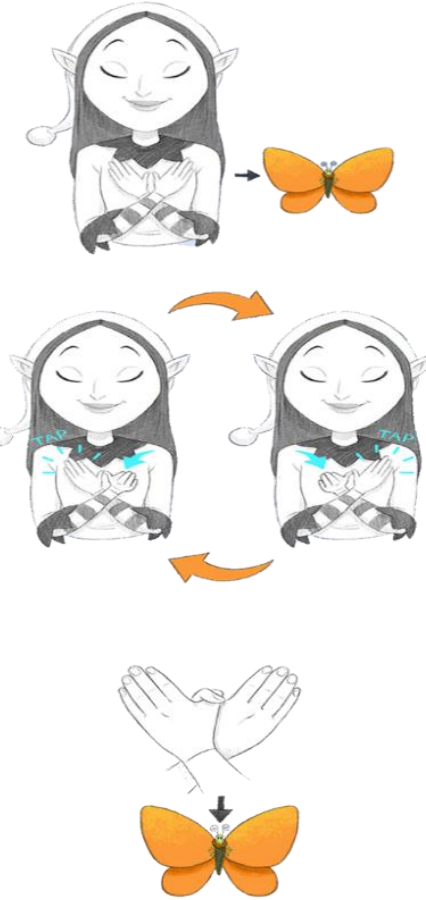

Gambar 8.1. Langkah-langkah butterfly hug. 


\section{TEKNIK MINDFULNESS}

Salah satu cara untuk mengatasi kecemasan selama pandemi sehingga tidak menjadi suatu gangguan psikologis adalah dengan teknik Mindfulness. Sebelumnya kenali dulu apa penyebab dari suatu perasaan cemas. Bila kita sudah mengetahui penyebab perasaan cemas ini adalah pikiran, maka kita bisa mencegahnya atau mengatasinya dengan mengelola pikiran. Mengelola pikiran yang dimaksud adalah dengan membawa kesadaran ke saat ini, di sini (here and now) yang dikenal dengan istilah mindfulness.

Mindfulness adalah kondisi dimana kita membawa kesadaran secara utuh saat ini. Jon Kabat Zinn (2015) memberikan pengertian mindfulness sebagai kondisi diri yang memberi perhatian dengan cara tertentu yaitu dengan memiliki tujuan, berada pada momen saat ini dan tidak menghakimi. Inti dari pengertian mindfulness ini adalah kita memperhatikan dengan penuh perhatian, pikiran, dan perasaan pada apa yang kita lakukan saat ini. Bila pikiran kita memikirkan hal yang akan datang, ingatkan kembali pada diri kita, apa yang kita lakukan sekarang, di mana kita berada saat ini, dan beri perhatian penuh, tanpa melabeli situasi saat ini sebagai situasi yang 'baik' atau 'buruk'.

Melatih diri untuk menjadi mindful atau berkesadaran utuh, tidaklah sulit, namun perlu kesadaran di dalam diri untuk terus menerus mengingatkan diri untuk kembali pada saat ini, di sini. Cara-cara yang bisa dilakukan antara lain adalah dengan menepuk-nepuk tubuh kita, bagian tangan, atau kaki, membawa kesadaran ke tubuh fisik kita; berhenti sejenak apabila pikiran sedang kacau, dan fokuslah pada pernafasan, perhatikan ritme nafas kita, masuk dan keluarnya udara ke 
dalam tubuh kita; kita juga bisa bercakap-cakap dengan diri ketika kita melakukan sesuatu. Misalnya, ketika kita sedang menyapu lantai, kita bisa berucap "saat ini saya sedang membersihkan lantai dari kotoran dan debu yang ada, dan juga saya membersihkan pikiran negative yang ada di dalam diri saya". Latihan mindfulness rutin yang membawa dampak yang sangat besar terhadap ketenangan pikiran adalah bermeditasi. Meditasi adalah Latihan untuk membawa pikiran fokus pada satu hal yang membuat pikiran kita relaks dan penuh kesadaran. Apabila Latihanlatihan tersebut secara konsisten dilakukan, maka kita tidak lagi dikontrol oleh pikiran yang menimbulkan kecemasan. Selamat berlatih!

\section{TEKNIK KEBERSYUKURAN (GRATITUDE)}

Bersyukur membuat perasaan lebih positif dan dapat meningkatkan kebahagiaan, yang turut memberi pengaruh positif pada tubuh fisik. Berikut beberapa cara yang bisa diterapkan untuk mengembangkan kebersyukuran:

1. Membuat catatan kebersyukuran (gratitude journaling).

Dalam latihan ini anda perlu buku catatan kebersyukuran. Anda hanya perlu menuliskan tiga sampai lima hal yang anda syukuri (jika anda bisa menuliskan dalam jumlah yang lebih banyak, bagus). Ketika anda menulisnya, rasakan kembali hal-hal tersebut memberi energi positif kepada anda. Anda dapat menulis jurnal setiap hari atau seminggu sekali, atau seminggu dua kali. Kuncinya adalah kesediaan untuk berlatih mensyukuri kehidupan anda. Jika anda tidak suka menulis di buku, anda bisa menuliskan di kertas dan memasukkan ke dalam kotak atau 
toples kaca. Sewaktu-waktu anda membutuhkan, anda dapat membacanya kembali.

2. Refleksi kebersyukuran.

Ini mirip dengan relaksasi dan meditasi berkesadaran. Dalam posisi yang rileks, rasakan sekeliling anda (cahaya, udara, suhu, dan lainnya) dan katakan "untuk hal ini, saya sangat bersyukur". Lalu arahkan kesadaran ke dalam diri anda, anda unik dan indah, dan katakan "untuk hal ini, saya sangat bersyukur". Terakhir anda menyadari keseluruhan perjalanan hidup anda, naik dan turunnya, segala pelajarannya, katakan "untuk hal ini, saya sangat bersyukur".

3. Batu kebersyukuran.

Kunci dari teknik ini adalah benda (bisa batu, bisa juga obyek lain) sebagai simbol kebersyukuran. Pilih batu yang anda sukai dan menurut anda menarik. Letakkan batu di tempat yang mudah terlihat dan bawa pergi bersama anda (bisa di kantong atau tas). Kapanpun anda melihat dan menyentuhnya, pikirkan hal-hal yang anda syukuri sepanjang hari itu. Bisa sesuatu yang sederhana seperti sinar matahari atau sesuatu yang besar seperti dapat bonus gaji. Ketika malam pegang kembali batunya dan ingat kembali hal yang disyukuri. Esok di pagi hari, ambil kembali bati dan ingat apa yang disyukuri kemarin. Ulangi prosesnya setiap hari.

\section{MENGGAMBAR BEBAS UNTUK MENGURANGI INTENSITAS EMOSI YANG TIDAK NYAMAN}

Menurut beberapa penelitian, menggambar terbukti dapat mengontrol emosi yang membuat kita merasa tidak nyaman yang sering dikatakan 
masyarakat sebagai emosi negatif, terutama bila dilakukan rutin. Menggambar dapat dijadikan media pengalihan emosi negatif dan juga sebagai media untuk melepaskan emosi negatif. Keduanya berdampak positif bagi emosi individu. Beberapa poin yang perlu diperhatikan saat menggambar bebas adalah:

4. Cek level emosi antara 1-5 dimana 1 adalah yang paling tidak nyaman dan 5 yang paling nyaman, ada di poin berapa emosi anda saat ini.

5. Gambarlah apapun yang ingin anda gambar tanpa perlu berpikir. Nikmati saat anda menggambar dan sadari segala sensasi yang muncul pada badan, emosi dan pikiran. Cukup sadari!

6. Alat dan bahan dapat disesuaikan dengan fasilitas yang ada. Bagus atau tidak bukanlah poin yang terpenting disini. Cukup ekspresikan dan nikmati tiap prosesnya.

7. Cek kembali level emosi (1-5), adakah sensasi di badan, pikiran dan emosi yang berubah. Ada atau tidaknya perubahan cukup sadari dan catat. Segalanya tidak memerlukan proses yang instan. Emosi yang muncul cukup diijinkan keluar, disadari apa pemicunya dan apa yang anda butuhkan.

8. Bila muncul perasaan tidak nyaman, lakukan butterfly hugs sambil mengucapkan kalimat positif yang ingin anda dengarkan dari seorang sahabat. Berlakulah sebagai sahabat bagi diri anda. Misalnya, saya sudah melakukan yang terbaik, saya akan baikbaik saja, saya kuat, wajar bila saya merasa sedih, dan kalimat positif lainnya yang mungkin berbeda tapi sangat ingin anda dengarkan dari seorang sahabat.

9. Lakukan rutin! 
Semoga dapat membantu mempercepat pemulihan jiwa dan fisik. Trust the process!

\section{RESILIENSI DAN KELINCAHAN DIRI DI TENGAH PANDEMI}

Berbagai tantangan di tengah pandemic menimbulkan situasi yang stressful bagi setiap individu. Isu keamanan dan kesehatan kerja, keberlanjutan proses pembelajaran, kesejahteraan psikologi (psychological wellbeing), stabilitas finansial, komunikasi dan ketersediaan koneksi merupakan beberapa contoh permasalahan yang harus dihadapi setiap individu dalam menghadapi masa pandemic ini. Perlu dipahami bahwa sesungguhnya permasalahan dapat dilihat dari dua sudut pandang, yaitu permasalahan yang dapat kendalikan dan permasalahan yang tidak dapat dikendalikan (Sumaryono, 2021). Saat ini setiap individu telah berproses dan menjalani situasi struggling, surviving, membangun kewaspadaan tinggi, hingga kemudian menjadi kreatif dan fleksibel, lebih adaptif, bahkan mulai membangun semangat "stand as One Family", saling peduli dan membantu. Reivich dan Shatte (2002) menjelaskan bahwa kemampuan individu untuk beradaptasi dan tetap teguh pada situasi sulit merupakan gambaran makna dari resiliensi. Semua individu memiliki kemampuan resiliensi, begitupun kemampuan untuk meningkatkan kapasitas serta siap menghadapi perubahan sebagai makna dari agility. Pribadi yang lincah, tangkas, dan gesit merupakan individu yang siap menghadapi tekanan, perubahan, bangkit dari kegagalan, serta mampu menemukan solusi atau pemecahan baru untuk permasalahan yang dihadapi, khususnya pada situasi krisis seperti saat ini. Selanjutnya mari mencermati situasi yang dihadapi dan sejauh mana masing-masing individu mampu menampilkan kemampuan 
resiliensi dengan menetralkan resiko, menggunakan resiko sebagai tantangan ke arah solusi yang diharapkan, dan menggunakan resiko yang ada sebagai upaya beradaptasi, tetap optimis dan berempati (Sumaryono, 2021).

Salam SEHAT dan KUAT untuk kita semua

$S=$ penuh semangat dan antusias

$\mathrm{E}=$ Empati

$\mathrm{H}=$ melayani dengan Hati yang Happy

$A=$ menjaga Akal dan Akhlak

$\mathrm{T}=$ Teguh dan berTekad

$\mathrm{K}=$ Kompeten

$\mathrm{U}=$ Unggul

$A=$ Adaptif, lincah (Agile)

$\mathrm{T}=$ Tangguh dalam menghadapi berbagai tantangan dan resiko

\section{DAFTAR PUSTAKA}

Kabat-Zinn, J. 2015. Mindfulness. Mindfulness, 6(6), 1481-1483.

Reivich, K., Shatte, A. 2002. The Resilience Factors: Seven Essentials skills for Overcoming Life's Inevitable Obstacles. Broadway Books.

Sumaryono. 2021. Seminar Virtual Kerjasama APIO Bali Himpsi Bali dan UNBI: Resiliensi adalah Kunci. 


\section{MENGELOLA KESEHATAN MENTAL SELAMA ISOLASI MANDIRI}

NK Sri Diniari, I Gusti Ayu Indah Ardani

Pandemi COVID-19 yang berkepanjangan dan tidak jelas akan berakhir memberi dampak luas terhadap semua kalangan masyarakat, baik secara fisik, sosial, maupun psikologis. Apalagi bila terpapar virus COVID-19 yang memberikan respon psikologis dari tingkat ringan sampai berat. WHO memberikan pedoman yang melibatkan penanganan pasienpasien COVID-19 secara komprehensif melibatkan tenaga professional psikologis agar angka morbiditas dan mortalitas bisa ditekan. Penaganan melibatkan nonfarmakologi dan farmakologi.

Pada penderita COVID-19 bergejala ringan-berat dilakukan isolasi mandiri. Selama menjalani isolasi mandiri, tentu saja aspek mental tidak bisa dipungkiri akan memberi kontribusi terhadap pemulihan pasien. Ada beberapa keluhan yang terjadi selama isolasi mandiri seperti gangguan tidur, stres, cemas/khawatir, jenuh/ burn-out, sedih, takut kehilangan, takut mati, dan gelisah/panik tidak tahu harus berbuat apa, dll.

Beberapa hal umum yang bisa dilakukan untuk mengurangi stres:

- Kurangi paparan berita yang berlebihan yang membuat kawatir, takut, kepikiran

- Lakukan olah raga atau aktivitas fisik yang ringan-sedang pada pagi/sore

- Minum susu hangat, makan pisang, rendam kaki dan tangan dengan air hangat 
- Lakukan Teknik relaksasi seperti bernafas dalam, mendengar musik yang menenangkan, menonton/mendengarkan acara yang membuat hati gembira, bersemangat atau termotivasi

- Bila sulit tidur, perlu kenyamanan ruangan dan tempat tidur; buka jendela siang hari agar ada cahaya masuk; kurangi melihat layar (gadget, TV, computer); kurangi tidur siang (tidak lebih dari 1 jam, jangan diatas jam 3 sore).

- Teknik menenangkan diri: menggerak-gerakakan tubuh, mandi air hangat, cari aroma yang menenangkan, terhubung dengan alam (melihat pemandangan, langit biru, bunga, dll), distraksi/ mengalihkan pikiran, membaca buku, bermain dengan binatang, dll

Manajemen stres:

- Jangka pendek

- Humor, tertawa

- Olah raga, peregangan

- Relaksasi, atur nafas

- Mengalihkan pd kegiatan fisik (terapi kerja)

- Berdoa

- Jangka panjang

- Curhat (videocall, WA group, line, telegram, dll)

- Mencari informasi ttg masalah yg sedang dihadapi (dalam hal ini informasi covid)

- Menghubungkan masalah dengan religious/spiritual

- Melakukan Latihan fisik untuk mengurangi ketegangan/masalah

- Membuat berbagai alternatif tindakan 
Lakukan "Me time"

- Penting mengendalikan pikiran $\rightarrow$ mindfullness

- Berbicara hal-hal positif dengan diri (afirmasi positif)

- Situasi kovid kesempatan mengenali diri, fisik, mental, kekuatan, kelemahan.

- Antisipasi beberapa kemungkinan yang bisa terjadi secara cerdas:

- Konsul ahli, call centre

- Vitamin

- Makanan bergizi

- Istirahat

- Oksimetri

- Makanan bergizi

Bila upaya umum tidak memberi perbaikan bisa melakukan penanganan yang lebih spesifik diantaranya:

- Teknik relaksasi nafas dalam

- Teknik distraksi (pengalihan)

- Meditasi/hipnotis 5 jari

- $\quad$ Progressive muscle relaxation (PMR)

\section{TEKNIK RELAKSASI NAFAS DALAM}

Melakukan latihan napas dalam dengan langkah langkah sebagai berikut:

1. Duduk santai di kursi/lantai

2. Mata tertutup/terbuka 
3. Otot-otot rileks : leher, bahu, punggung, dada, perut, tangan, kaki

4. Tarik napas perlahan melalui hidung 3 detik, tahan 3 detik

5. Hembuskan napas perlahan melalui mulut dengan ujung lidah tempel keatas dan bibir bentuk bulat kecil 3 detik

6. Lakukan 5-10 kali

\section{TEKNIK DISTRAKSI}

- Visual: melihat pemandangan alam di daerah pantai, pegunungan, hutan dan taman

- Audio: mendengar suara alam seperti : air mengalir, kicauan burung atau musik lembut

- Kinetik: melakukan kegiatan hiburan seperti : menonton film komedi/ kartun, membaca novel, membaca kata-kata dengan huruf terbalik, mengunyah permen karet, melihat benda-benda sekitar, mendekatkan dua jari sedekat mungkin berulang-ulang

\section{MEDITASI/HIPNOTIS 5 JARI}

Langkah langkah sebagai berikut bisa dilakukan 2-3 kali sehari:

1. Duduk santai, mata tertutup, tubuh rileks

2. Fokuskan diri pada nafas kita yang pelan \& teratur

3. Sentuhkan ujung ujung jari dan bangun imajinasi

a. Ibu jari dengan telunjuk: bayangkan sedang melakukan aktivitas hobi atau rekreasi

b. Ibu jari dengan jari tengah: bayangkan sedang berbicara akrab dengan orang yang disayangi

c. Ibu jari dengan jari manis: bayangkan sedang bersyukur mendapat pujian atas prestasi yang pernah ada 
d. Ibu jari dengan kelingking: bayangkan berada di tempat yang damai dengan pemandangan alam yang indah bersama orang yang disayangi
4. Buka mata perlahan-lahan

\section{PROGRESSIVE MUSCLE RELAXATION (PMR)}

1. Atur nafas pelan dan relaks

2. Sambil Tarik nafas pelan, kencangkan seluruh otot sambil menarik nafas, dan hitung $1 \ldots 2 \ldots 3 \ldots$ ( \pm 3 detik)

3. Kemudian kencangkan semaksimal mungkin semua otot (dari ujung kepala-kaki) sambil menahan nafas $1 \ldots 2 \ldots 3 \ldots$

4. Hembuskan nafas pelan-pelan $1 \ldots 2 \ldots 3 \ldots$ sambil relakkan seluruh otot tubuh (dari otot kepala-kaki) serilek-rileknya

5. Lakukan 5 kali dalam satu sesi

6. Lakukan 2-3 $x$ sehari, bisa sambil duduk, maupun tidur

Bila upaya di atas tidak memberikan perbaikan, dan keluhan yang dirasakan belum mebaik dan sangat menganggu diperlukan konsultasi ke psikiater untuk mendapatkan psikofarmakologi dan psikoterapi (terapi kognitif perilaku, interpersonal terapi, logoterapi, terapi realitas, dll). Pada keadaan cemas berlebih atau sedih berlebih akan diberikan obat obatan sesuai dengan indikasi misalnya pada keadaan cemas berlebih akan diberikan anticemas, pada kondisi kalut/sedih akan diberikan obat yang meningkatkan perasaan bahagia, bila emosi tidak stabil akan diberikan mood stabilizer. Konsultasi ke psikiater dapat dilakukan dengan telemedicine yang akan memberikan layanan konseling dan pemberian obat-obatan apabila diperlukan. 


\section{DAFTAR PUSTAKA}

Sumaryono. 2021. Seminar Virtual Kerjasama APIO Bali Himpsi Bali dan UNBI: Resiliensi adalah Kunci

Aji, I. P. D. K. et al., 2021. Mindfulness Based Cognitive Therapy to Psychiatric Resident of Udayana University: Sanglah General Hospital. International Journal of Pharmaceutical, 13(2).

Call, D., Miron, L. \& Orcutt, H., 2013. Effectiveness of Brief Mindfulness Techniques in Reduction Symptoms of Anxiety and Stress. Springer Science, 5(6), pp. 658-668.

Hofmann, S. G., Sawyer, A. T., Witt, A. A. \& Oh, D., 2010. The Effect of Mindfulness-Based Therapy on Anxiety and Depression: A MetaAnalytic 34 Review. Journal of Consulting and Clinical Psychology, Volume 78, pp. 169-183.

Jayasinghe R. 2017. Relaxation Techniques for stress management. Institute of mental health (IMH). Colombo-04 Sri Lanka.

Widyastuti P, Yulianti D. 2004. Manajemen stress. National Safety Council. Penerbit buku kedokteran. EGC. ISBN 979-448-624-8

Witte, M. d. et al., 2020. Effects of Music Intervention on Stress-Related Outcomes: A Systematic Review and Two Meta-Analysis. Health Psychology Review. 


\section{NUTRISI UNTUK WARGA YANG ISOLASI MANDIRI}

Agustinus I Wayan Harimawan, Gde Ngurah Indraguna Pinatih, Wayan

Gede Sutadarma, I Wayan Weta, Ni Ketut Sumartini, Syuma Adhy

Awan, Putu Roseputri Bajirani, Ni Made Dwi Asti Lestari

Pada dasarnya tubuh kita memiliki mekanisme pertahanan yang diperankan oleh sel-sel imun terhadap benda asing termasuk virus, namun pada kondisi terpaparnya tubuh oleh virus SAR-COV2 yang membawa antigen lebih banyak sehingga sel sel imun kewalahan mengatasi serangan ini. Sebagai akibatnya terjadi peradangan pada tubuh yang berlebih dan memperburuk keadaan penderita. Pada saat ini diperlukan upaya untuk meningkatkan fungsi imun, maka dari itulah dibutuhkan zat gizi yang lebih tinggi khususnya vitamin dan mineral. Zat gizi makro (karbohidrat, protein dan lemak) sebagai sumber energi disesuaikan dengan proporsi rendah karbohidrat terutama gula sederhana (tinggi indek glikemik) dan cukup serat (rendah FOODMAP), untuk menghindari mual, mengurangi beban metabolik tubuh dan menekan peradangan yang berlebih.

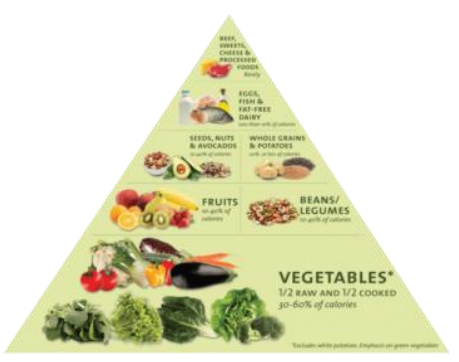

Gambar 9.1. Piramida makanan untuk gizi seimbang. 
Hal-hal yang perlu diperhatikan selama Isoman:

1. Makanan pokok sebagai sumber karbohidrat seperti nasi, jagung, ubi dan sebagainya dikonsumsi dengan jumlah tidak lebih dari seperempat piring, dan gula sederhana seperti gula pasir, gula merah, susu kental manis, soft drink, selai, dan tepung tepungan termasuk kerupuk dikonsumsi sesedikit mungkin atau dihindari..

2. Lauk pauk sebagai sumber protein dapat berasal dari hewan maupun nabati. Bahan protein hewani terutama daging merah dan daging yang berlemak, diproses, digoreng harus dikurangi. Protein nabati seperti kacang kacangan, biji bijian, tahu dan tempe, jenis yang dikonsumsi lebih beragam

3. Minyak jenuh seperti minyak kelapa sawit, minyak sayur, minyak jagung termasuk minyak trans (mentega, minyak bekas) harus dihindari. Minyak tidak jenuh dengan kandungan omega 3 tinggi dan minyak tidak jenuh tunggal seperti minyak canola, minyak olive, minyak avocad. Untuk menambah sumber lemak virgin coconut oil baik untuk dikonsumsi

4. Konsumsi buah dan sayur sebagai sumbar vitamin, mineral dan antioksidan harus diutamakan. Separuh dari porsi makan kita diisi dengan sayur dan buah. Buah dan sayuran yang dikonsumsi harus bervariasi jenis dan warnanya seperti pelangi, karena kandungan zat gizi yang terkandung di dalamnya sangat beragam berdasarkan warnanya.

5. Makanan sudah diproses dan dikemas sebaiknay dihindari oleh karena banyak mengandung zat tambahan makanan (pengawet, penambah rasa, pewarna) yang pada umumnya tidak sehat. 


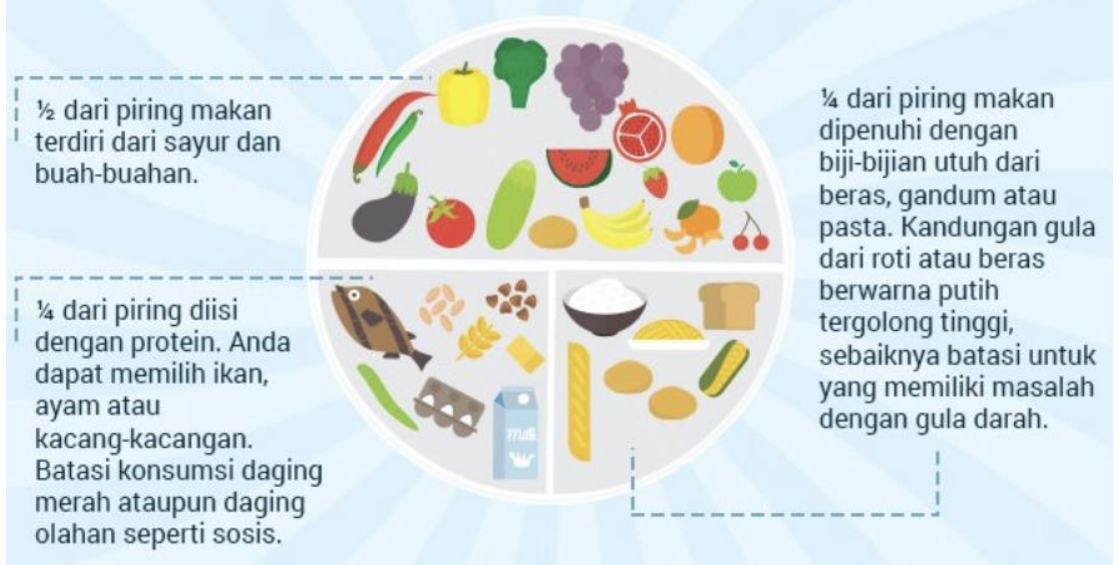

Gambar 9.2. Keseimbangan gizi dalam sajian.

\section{MENGAPA HARUS SAYUR DAN BUAH?}

Karena sayur dan buah kaya akan vitamin, mineral, prebiotik, flavonoid dan serat yang semuanya itu dibutuhkan oleh tubuh agar sel-sel kekebalan tubuh dapat bekerja dengan dengan baik.

Konsumsi buah dan sayur dalam menu makanan sehari dengan jumlah sayur sebanyak dua setengah gelas dan buah $3-5$ porsi. Konsumsilah sayur dan buah yang beraneka warna seperti:

1. Sayuran dan buah warna hijau adalah sumber karoten yang baik akan antioksidan

2. Sayuran dan buah berwarna ungu kaya akan vitamin yang dibutuhkan oleh sel-sel kekebalan tubuh sehingga dapat meningkatkan kekebalan tubuh. 
3. Sayuran dan buah berwarna kuning dan orange juga kaya akan vitamin dan antioksidan yang dibutuhkan oleh sel-sel kekebalan tubuh sehingga respon kekebalan akan bekerja dengan optimal pada saat dibutuhkan.

4. Sayuran dan buah berwarna merah merupakan sumber yang baik akan vitamin $\mathrm{A}$ dan vitamin $\mathrm{E}$ yang diperlukan oleh tubuh untuk menjaga pembuluh darah dan antioksidan terhadap sel kanker.

5. Sayuran dan buah berwarna putih merupakan sumber yang baik untuk vitamin $E$, kalsium dan zat alicin yang dapat mengontrol kadar kolesterol, tekanan darah dan dan menghambat pertumbuhan sel kanker.

6. Makanan yang kaya akan probiotik adalah makanan yang telah difermentasi seperti tempe, yoghurt dan kefir.

\section{SUPPLEMENTASI}

Dalam kondisi menderita COVID-19 kebutuhan akan vitamin dan mineral akan sangat tinggi sehingga diperlukan supplementasi, karena dari sumber makanan saja dikuatirkan belum cukup memnuhi kebutuhan.

Supplement yang disarankan adalah:

1. Vitamin C, non acidic diminum $500 \mathrm{mg}$ setiap 6-8 jam selama 14 hari. Atau vitamin $\mathrm{C}$ tablet hisap $500 \mathrm{mg}$, dikonsumsi setiap 12 jam selama 30 hari.

2. Multivitamin dan mineral dikonsumsi satu tablet setiap hari selam 30 hari 
3. Vitamin D3 sebagai suplemen diminum 400-1000 IU/hari. Tetapi kalau sebagai obat diminum 1000-5000IU/hari.

4. Probiotik dan prebiotic.

Tabel 10.1. Contoh Menu Diet Untuk Isoman + mual/ dispepsia (Rendah Indeks Glikemik dan FOODMAP).

\begin{tabular}{|c|c|c|c|}
\hline Jenis makanan & Bahan makanan & Indeks Glikemik & Beban Glikemik \\
\hline \multirow[t]{6}{*}{ Serealia } & Beras Basmati & 58 & 22 \\
\hline & Beras coklat & 50 & 16 \\
\hline & Beras putih & 87 & 36 \\
\hline & Mie instan & 7 & 19 \\
\hline & Bihun & 35 & 16 \\
\hline & Spaghetti & 38 & 18 \\
\hline \multirow[t]{6}{*}{ Roti, crackers, cake } & Roti tawar putih & 70 & 10 \\
\hline & Roti tawar gandum & 77 & 9 \\
\hline & Cracker & 78 & 14 \\
\hline & Cookies oatmeal & 55 & 12 \\
\hline & Sponge cake & 46 & 17 \\
\hline & Waffles & 76 & 10 \\
\hline \multirow[t]{9}{*}{ Sayur } & Wortel & 47 & 3 \\
\hline & Kacang polong & 48 & 3 \\
\hline & Kentang panggang & 85 & 26 \\
\hline & Kentang rebus & 88 & 16 \\
\hline & Kentang goreng & 75 & 22 \\
\hline & Labu & 75 & 3 \\
\hline & Jagung manis & 60 & 11 \\
\hline & Ubi jalar & 61 & 17 \\
\hline & Ketela & 37 & 13 \\
\hline \multirow[t]{3}{*}{ Kacang-kacangan } & Kacang merah & 28 & 7 \\
\hline & Kedelai & 18 & 1 \\
\hline & Kacang-kacangan & 29 & 5 \\
\hline \multirow[t]{10}{*}{ Buah } & Apel & 38 & 6 \\
\hline & Pisang & 51 & 13 \\
\hline & Anggur & 46 & 8 \\
\hline & Mangga & 51 & 8 \\
\hline & Jeruk & 48 & 5 \\
\hline & Pepaya & 59 & 10 \\
\hline & Pir & 38 & 4 \\
\hline & Nanas & 59 & 7 \\
\hline & Melon & 65 & 4 \\
\hline & Semangka & 72 & 4 \\
\hline Olahan susu & Susu full cream & 27 & 3 \\
\hline
\end{tabular}




\begin{tabular}{|l|l|l|l|}
\hline \multirow{4}{*}{ Minuman } & Susu skim & 32 & 4 \\
\cline { 2 - 4 } & Susu cokelat & 42 & 13 \\
\cline { 2 - 4 } & Susu bubuk & 61 & 33 \\
\cline { 2 - 4 } & Es krim & 61 & 8 \\
\cline { 2 - 4 } & Yogurt low fat & 33 & 10 \\
\hline Gula dan pemanis & Jus apel & 40 & 12 \\
\cline { 2 - 4 } & Coca-cola & 63 & 16 \\
\cline { 2 - 4 } & Fanta & 68 & 23 \\
\cline { 2 - 4 } & Jus jeruk & 52 & 12 \\
\cline { 2 - 4 } & Cokelat & 44 & 13 \\
\cline { 2 - 4 } & Madu & 55 & 10 \\
\cline { 2 - 4 } & Gula pasir & 68 & 10 \\
\cline { 2 - 4 } & Glukosa & 100 & 2 \\
\cline { 2 - 4 } & Fruktosa & 19 & 5 \\
\cline { 2 - 4 } & Laktosa & 46 & \\
\hline
\end{tabular}

\section{Keterangan}

$$
\begin{aligned}
& =\text { indeks glikemik indek tinggi, dihindari } \\
& \square=\text { indeks glikemik sedang, dibatasi } \\
& \square=\text { indeks glikemik rendah, disarankan }
\end{aligned}
$$

Tabel 10.2. Bahan Makanan Rendah FODMAP.

\begin{tabular}{|l|l|l|}
\hline $\begin{array}{l}\text { Sumber } \\
\text { Makanan }\end{array}$ & Disarankan & Dihindari \\
\hline Sayur & $\begin{array}{l}\text { Tauge, tomat, selada wortel, } \\
\text { mentimun, kacang panjang, } \\
\text { brokoli }\end{array}$ & $\begin{array}{l}\text { bawang putih, } \\
\text { buncis, bawang } \\
\text { merah }\end{array}$ \\
\hline Buah & $\begin{array}{l}\text { pepaya,pisang,stroberi, } \\
\text { nanas, anggur, melon }\end{array}$ & $\begin{array}{l}\text { blacberry, } \\
\text { semangka, } \\
\text { mangga. Pir }, \\
\text { apel }\end{array}$ \\
\hline Protein & $\begin{array}{l}\text { Daging ayam, telur, ikan, tofu, } \\
\text { tempe }\end{array}$ & $\begin{array}{l}\text { Daging olahan } \\
\text { (sosis, nugget) }\end{array}$ \\
\hline Lemak/minyak & Sawit, Canola, VCO, Zaitun & $\begin{array}{l}\text { Almond, } \\
\text { kacang, alpukat }\end{array}$ \\
\hline $\begin{array}{l}\text { Karbohidrat, pati, } \\
\text { sereal, gandum }\end{array}$ & $\begin{array}{l}\text { Nasi putih, oat, kentang, ubi } \\
\text { ungu, jagung }\end{array}$ & $\begin{array}{l}\text { Kacang polong, } \\
\text { roti berbahan } \\
\text { gluten }\end{array}$ \\
\hline
\end{tabular}


Tabel 10.3. Contoh diet $1800 \mathrm{kkal}$, protein $80 \mathrm{gr}$, karbohidrat $130-150 \mathrm{gr}$, dan lemak $70 \mathrm{gr}$, senilai 7 sendok makan.

\begin{tabular}{|c|c|}
\hline Jam & Menu Diet \\
\hline $\begin{array}{l}\text { Pagi } \\
06.00-\end{array}$ & Sup daging ikan/ayam direbus (60 gr) \\
\hline $\begin{array}{l}\text { Sarapan } \\
08.00-09.00\end{array}$ & $\begin{array}{l}\text { Roti gandum panggang ( } 2 \text { potong) }+2 \text { telur mata } \\
\text { sapi + buah utuh (papaya } 1 \text { porsi })+ \text { minyak } 2 \\
\text { sdk makan utk memasak }\end{array}$ \\
\hline $\begin{array}{l}\text { Snack } \\
10.00\end{array}$ & $\begin{array}{l}\text { Overnight oatmeal } 1 \text { gelas }(220 \mathrm{ml}) \text { atau } \\
\text { Jus Anggur + bawang putih lanang } 1 \text { ruas + } \\
\text { madu } 1 \mathrm{sdk}+\text { air perasan jeruk } 150 \mathrm{ml}\end{array}$ \\
\hline $\begin{array}{l}\text { Makan siang } \\
12.00-13.00\end{array}$ & $\begin{array}{l}\text { Brokoli rebus ditumis dan dicampur dengan } \\
\text { bawang putih ( } 2 \text { cangkir) + } 1 \text { cangkir nasi merah } \\
(40 \text { gram })+\text { tuna panggang dengan bumbu } \\
(60 \mathrm{gr})+\text { Tahu kukus } 110 \mathrm{gr} / \text { tempe } 50 \mathrm{gr} \text { (minyak } \\
2-3 \text { sdk makan utk proses masak) } \\
+ \text { Smoothie Pisang dan Yogurt }\end{array}$ \\
\hline $\begin{array}{l}\text { Snacks } \\
15.00\end{array}$ & $\begin{array}{l}\text { Teh chamomile + air jahe + Ubi jalar ungu kukus } \\
\text { 1 potong ATAU salad tauge (direbus) }\end{array}$ \\
\hline $\begin{array}{l}\text { malam } \\
18.00\end{array}$ & $\begin{array}{l}\text { Sup Jagung/Asparagus + Ayam panggang/ } \\
\text { Dada Ayam /Bebek panggang / telur rebus (120 } \\
\text { gr) dengan tumis sayuran mentimun, kacang } \\
\text { panjang ,bawang putih + Nasi merah } 1 \text { cangkir } \\
+(\text { minyak } 2-3 \text { sdk makan utk proses masak) }\end{array}$ \\
\hline
\end{tabular}

\section{OVERNIGHT OATMEAL KLASIK}

Bahan-bahan yang dibutuhkan: 
- $1 / 3$ cangkir yogurt greek, atau yogurt polos

- $1 / 2$ cangkir oatmeal instan

- 5 sendok makan susu sapi segar

- 1 sendok makan biji chia (chia seeds)

- $\quad 1 / 2$ sendok teh ekstrak vanili

- Sejumput garam

- 2 sendok makan madu

Cara membuatnya

1. Campurkan semua bahan ke dalam mangkuk menjadi satu, lalu aduk hingga merata

2. Tutup dan diamkan selama 4 jam di dalam kulkas. Lebih disarankan untuk mendiamkan semalaman dan dikonsumsi pagi harinya.

\section{SUP GANDUM AYAM/IKAN}

Bahan bahan yang dibutuhkan

- Serlia/biji bijian/oatmeal dimasak - 80g

- Potongan dada ayam/ikan - 85g

- Wortel cincang - $50 \mathrm{~g}$

- Brokoli cincang - $44 \mathrm{~g}$

- Garam - 0.4g

Cara membuatnya

1. Rebus ayam dalam panci.

2. Tambahkan sereal, wortel, dan brokoli. 
3. Kecilkan api, tutup dan masak selama 10 menit.

4. Tambahkan garam.

\section{SMOOTHIE PISANG DAN YOGURT}

Bahan-bahan yang dibutuhkan

- Yoghurt organik - $100 \mathrm{~g}$

- $\quad$ Pisang - 1-2

- $M a d u-20 \mathrm{~g}$

Cara mempersiapkannya:

1. Masukkan semua bahan ke dalam blender. Tambahkan es jika perlu.

2. Blender dan sajikan.

\section{SALAD TAUGE}

Bahan-bahan:

- 100 gram tauge

- 2 siung bawang putih

- $1 / 2$ sdm bubuk cabai

- $1 \mathrm{sdm}$ kecap asin

- 1 sdm minyak wijen

- Garam secukupnya

Pelengkap: 
- Wijen putih

Cara membuatnya:

1. Panaskan air secukupnya pada panci untuk merebus tauge. Perhatikan teksturnya, jangan sampai overcooked.

2. Siapkan wadah berupa baskom atau mangkuk.

3. Tuang minyak wijen, kecap asin, garam, serta bubuk cabai tambahkan bawang putih yang sebelumnya sudah dihaluskan.

4. Masukan tauge rebus kedalam wadah berisi bumbu salad.

5. Aduk semua bahan tersebut agar bumbu tercampur merata dengan tauge. Sebagai pelengkap, beri taburan biji wijen 


\section{DAFTAR PUSTAKA}

Ng,W.H.,Tipih, ETAL.,2021, Comorbidities in SARS-CoV-2 Patients a Systematic Review and Meta-Analysis, 12(1)e03647-20, doi 10.1128mBio.03647-20.

Sanyaolu, A., ETAL., (2020). Comorbidity and its Impact on Patients with COVID-19, SN Comprehensive Clinical Medicine. doi:10.1007/s42399-020-00363-4

Klang E, etal, 2020. Severe obesity as an independent risk factor for COVID-19 mortality in hospitalized patients younger than 50, Obesity (Silver Spring) 28:1595-1599. https://doi.org/10.1002/oby.22913.

Yanai,H, 2020, Metabolic Syndrome and COVID-19, Cardiol Res. 2020 Dec; 11(6) 360-365. doi: https://doi.org/10.14740/cr1181

Malavazos,A., etal., Targeting the Adipose Tissue in COVID-19, Obesity (Silver Spring) 2020 Jul;28(7)1178-1179. doi 10.1002oby.22844.

Morais, A. H. de A., etal., 2020, Obesity and the increased risk for COVID19: mechanisms and nutritional management, Nutrition Research Reviews, 1-34. doi:10.1017/s095442242000027x

Ryan, D. H., Ravussin, E., \& Heymsfield, S. (2020), COVID 19 and the Patient with Obesity - The Editors Speak Out. Obesity. doi:10.1002/oby.22808

Stefan, N., etal, 2020, Obesity and impaired metabolic health in patients with COVID-19. Nature Reviews Endocrinology. doi10.1038s41574-020-0364-6

Chen, J., Wu, C., etal., 2020, The Impact of COVID-19 on Blood Glucose A Systematic Review and Meta-Analysis. Frontiers in Endocrinology, 11. doi10.3389fendo.2020.574541 
Pranata,R.,etal., 2021, Diabetes and COVID-19 The past, the present, and the future.httpsdoi.org10.1016j.metabol.2021.15481415.

Orioli, L., etal., 2020. COVID-19 in diabetic patients: related risks and specifics of management, Annales d'Endocrinologie. doi:10.1016/j.ando.2020.05.001

Lim, S., Bae, J. H., Kwon, H.-S., \& Nauck, M. A.,(2020, COVID-19 and diabetes mellitus from pathophysiology to clinical management, Nature Reviews Endocrinology, doi10.1038s41574-020-00435-4

Landstra,C.P and de Konin,E.J.P.,2021, COVID-19 and Diabetes Understanding the Interrelationship and Risks for a Severe Course, Front. Endocrinol., 17 June 2021 httpsdoi.org10.3389fendo.2021.649525

Unnikrishnan,R \& Misra,A, 2021, COVID-19 and diabetes A bidirectional relationship, Clin Investig Arterioscler. 2021 May-June; 33(3) 151157. doi 10.1016j.arteri.2020.10.001

Buku Pedoman Tatalaksana COVID-19 5OP Edisi 32020

Muscogiuri, G., Barrea, L., Savastano, S., \& Colao, A., 2020. Nutritional recommendations for CoVID-19 quarantine. European Journal of Clinical Nutrition. doi10.1038s41430-020-0635-2

Shapira., 2019. The Metabolic Concept of Meal Sequence vs. Satiety Glycemic and Oxidative Responses with Reference to Inflammation Risk, Protective Principles and MediterrDiet, Nutrients, 11(10), 2373

D M Minich and P J Hanaway, 2020,The Functional Medicine Approach to COVID-19 Nutrition and Lifestyle Practices for Strengthening Host Deffence, Integr Med (Encinitas), 2020 May 9;19(Suppl 1)5462. 
Killian,L, 2021, High (FODMAP) Consumption Among Endurance Athletes and Relationship to Gastrointestinal Symptoms, Frontiers in Nutrition, 2021 Apr 20;8637160. doi 10.3389

Gangitano,E., et al., 2021, Ketogenic Diet as a Preventive and Supportive Care for COVID-19 Patients, Nutrients, 13, 1004. httpsdoi.org10.3390nu13031004

Paoli,A., etal., 2021,2020, The dark side of the spoon - glucose, ketones and COVID-19 a possible role for ketogenic diet, J Transl Med, 2020 Nov 20;18(1)441. doi 10.1186s12967-020-02600-9 


\section{KESEHATAN REPRODUKSI DAN SEKSUAL SELAMA ISOLASI MANDIRI}

I Gusti Ngurah Pramesemara, Made Oka Negara

\section{SEKILAS KESEHATAN REPRODUKSI DAN SEKSUAL}

Sudah satu setengah tahun lebih pandemi COVID-19 berjalan dan belum pasti kapan selesai atau mulai terkendali. Kehidupanpun akhirnya berubah dan harus beradaptasi, tidak terkecuali kondisi kesehatan reproduksi dan seksual.

Aspek reproduksi dan seksualitas adalah dua hal yang tidak terpisahkan, saling berhubungan satu sama yang lain, dan turut menentukan kualitas hidup manusia. Menurut Organisasi Kesehatan Dunia (WHO), secara umum kesehatan seksual berarti segala sesuatu yang berkaitan dengan keadaan fisik, emosional, mental dan kesejahteraan sosial dalam kaitannya dengan seksualitas, dan bukan hanya tidak adanya penyakit, disfungsi atau kelemahan. Reproduksi sendiri berfokus pada tujuan untuk menghasilkan keturunan selanjutnya, sedangkan hubungan seksual sebagai bentuk aktivitas untuk bereproduksi.

\section{KESEHATAN REPRODUKSI DAN SEKSUAL SELAMA PANDEMI}

Telah dilaporkan beberapa kejadian yang mengganggu kesehatan reproduksi dan seksual akibat dari COVID-19 terutama yang ditemukan pada laki-laki. Namun, perkembangan teknologi reproduksi berbantu saat ini sudah sangat maju dan mampu menjadi solusi ampuh bagi 
permasalahan reproduksi terutama problem ketidaksuburan yang seringkali muncul, termasuk yang disebabkan akibat virus SARS CoV2.

Sebuah penelitian melaporkan seperempat lebih laki-laki yang terinfeksi COVID-19 mengalami perburukan hasil Analisis Sperma dengan disertai munculnya tanda-tanda peradangan saluran reproduksi. Sampai saat ini, baru satu penelitian yang melaporkan ditemukannya virus SARS-CoV2 di dalam cairan sperma. Sehingga belumlah dimungkinkan untuk menarik sebuah kesimpulan pasti dan diperlukan beberapa kajian atau penelitian lebih lanjut untuk memperkuatnya. Tetapi kondisi di atas harus menjadi pertimbangan bahwa COVID-19 mungkin berpotensi mengganggu proses produksi sperma (spermatogenesis), menurunkan kualitas sperma dan kemungkinan menjadi media penularan.

Mengenai komponen seksualitas manusia, terdiri dari dorongan seksual atau libido, bangkitan seksual atau arousal, dan diakhiri dengan puncak kenikmata seksual atau orgasme. Fungsi seksual tidak melulu untuk bereproduksi (prokreasi), tetapi termasuk juga untuk mencari kebahagiaan (prorekreasi), menjaga ikatan relasi dan keutuhan rumah tanga (prorelasi dan proinstitusi), dan tentu saja telah terbukti dapat menjaga kesehatan secara umum (prosehat). fungsi seksual yang terjaga baik, akan membuat seluruh komponen seksualitas dapat berjalan optimal. Mulai dari gairah seks yang baik, berlanjut kepada ereksi dan kontrol ejakulasi pada laki-laki yang juga baik, sementara pada perempuan terjadi ereksi klitoral, perlendiran (lubrikasi), serta relaksasi vagina yang baik, sehingga aktivitas seksual dapat berlangsung dengan baik, untuk mencapai orgasme dan kepuasan seksual yang maksimal. 
Kondisi kehidupan seksual yang sehat dan memuaskan juga menentukan kualitas hidup manusia.

Kehidupan seksual selama pandemi terlaporkan cukup beragam, mulai dari sejumlah pasangan yang semakin bergairah dengan frekuensi hubungan seksual yang meningkat, hingga terjadinya kasus-kasus disfungsi seksual, baik karena penyebab fisik maupun psikis. Sebelumnya COVID-19 telah banyak dilaporkan memengaruhi kemampuan atau fungsi seksual baik pada laki-laki maupun perempuan yang mengidapnya. Saat ini banyaknya informasi negatif yang beredar tentang COVID-19 menjadi stressor yang timbul selama menjalankan isolasi mandiri juga dapat menyebabkan gangguan seksual. Kondisi ini cenderung ditemui pada perempuan karena risiko yang lebih besar untuk mengalami gangguan kecemasan dan depresi selama pandemi atau ketika menjalani isolasi mandiri. Sementara di sebuah penelitian terbaru bahkan berhasil membuktikan terjadinya kerusakan sel-sel penyusun pembuluh darah atau disfungsi sel sendotel yang meluas akibat infeksi COVID-19 yang dapat menyebabkan disfungsi ereksi.

\section{AKTIVITAS SEKSUAL SELAMA PANDEMI}

Lalu bagaimana dengan aktivitas seksual? Aktivitas seksual yang dilakukan bersama pasangan, tentu saja biasanya melibatkan kontak fisik tanpa jarak. Perhatian khusus dalam kontak seksual adalah menghindari kontak droplet dan air liur sebagai risiko sumber penularan utama, dan juga kontak dengan feses yang juga dianggap memiliki potensi menularkan berdasarkan hasil beberapa penelitian. 
Untuk itu, berikut adalah rekomendasi melakukan aktivitas seksual selama pandemi ini:

1. Jika kedua pasangan bebas virus SARS-CoV2 dan tidak ada kontak fisik dengan orang lain, maka aman untuk melakukan aktivitas seksual, termasuk hubungan seksual.

2. Jika salah satu atau keduanya pernah kontak fisik jarak dekat dengan orang lain, pastikan keduanya bebas virus SARS-COV2.

3. Lakukan tes COVID-19. Jika keduanya negatif, maka bebas melakukan aktivitas seksual apapun tanpa menggunakan masker.

4. Tetapi jika tidak dilakukan tes COVID-19 dan tidak yakin apakah pasangan bebas dari COVID-19, hindari kontak mulut dan hidung. Hubungan seksual dengan posisi berhadapan harus tetap menggunakan masker.

5. Hubungan seksual dengan laki-laki dari belakang, lebih bebas, bisa tanpa masker, asal tidak melakukan ciuman, terutama ciuman dalam.

6. Jika mengalami gangguan seksual, dapatkan pengobatan yang benar. Jangan membeli obat atau ramuan apapun terkait seks tanpa petunjuk dokter, termasuk melalui daring.

7. Dapatkan vaksinasi sesuai prosedur.

8. Dalam keadaan tertentu, jika tidak dapat melakukan hubungan seksual, dapat melakukan masturbasi.

Sekali lagi, sempat dilaporkan bahwa virus SARS-COV2 juga ditemukan ada pada cairan sperma, tetapi belum jelas dipastikan apakah dapat mengakibatkan penularan. Untuk lebih amannya, hubungan seksual dapat dilakukan dengan menggunakan kondom. Apalagi jika 
tidak menginginkan terjadi kehamilan, dengan pilihan alasan jika terjadi penularan virus SARS CoV2 saat hamil akan memiliki risiko lebih berat dibanding jika tidak hamil. Dan karena dugaan penularan bisa terjadi dari kontak dengan feses, maka aktivitas kontak lidah dengan anus (analingus) atau juga disebut "rimming" harus dihindari. Saat ini perlu dibiasakan sebelum dan sesudah berhubungan seksual untuk mandi.

Untuk posisi berhubungan seksual, jika dilakukan secara berhadapan, baik itu tidur, berdiri, ataupun duduk, wajib kedua pasangan menggunakan masker. Sedangkan posisi tidak berhadapan dengan pihak laki-laki dari belakang, baik itu tidur, berdiri, ataupun duduk, masih bisa tanpa menggunakan masker.

\section{AKTIVITAS SEKSUAL SAAT ISOLASI MANDIRI}

Isolasi mandiri dapat dilakukan di rumah atau di tempat khusus yang disediakan oleh pemerintah, dengan tetap membutuhkan pemantauan. Saat ini ditetapkan bahwa isolasi mandiri dilakukan selama 10 hari, dan jika sudah tidak ada gejala apapun lagi, dapat dilanjutkan dengan tambahan 3 hari lagi. Jika sampai hari ke 10 ternyata masih ada gejala, maka isolasi dilanjutkan kembali sampai gejala hilang, selanjutnya dapat dilanjutkan 3 hari dari bebas gejala. Jika dalam kurun waktu tersebut, gejala memberat dan perlu perawatan khusus, yang harus dilakukan adalah segera mendapatkan perawatan ke pusat layanan kesehatan atau rumah sakit.

Selanjutnya dilihat kondisi isolasi mandirinya. Apakah isolasi mandiri bersama dalam tempat karena keduanya positif? Apakah salah satu saja yang positif, tetapi berada dalam satu tempat yang sama? Atau 
saat isolasi mandiri tidak di tempat yang sama? Tentu saja, yang perlu diperhatikan pertama adalah tujuan dari isolasi mandiri, adalah untuk memisahkan antara yang mengidap COVID-19 dari yang sehat tidak mengidap COVID-19 agar tidak terjadi penularan. Kemudian membuat yang isolasi mandiri bisa menyelesaikan masa isolasinya dengan tuntas dan sehat kembali, baik yang tidak bergejala, maupun yang bergejala ringan. Prioritas pertama adalah menjaga daya tahan tubuh tetap terjaga dengan melakukan pola hidup sehat dan tambahan dukungan fisik, psikis, sosial, dan terapi tambahan seperlunya. Jika aktivitas seksual, terutama hubungan seksual bisa ditunda sampai menyelesaikan masa isolasi, maka itu bisa dilakukan, dan selanjutnya dapat mulai dilakukan setelah isolasi mandiri tuntas. Tetapi cukup banyak orang ternyata memerlukan untuk melakukan hubungan seksual dengan tujuan relaksasi dan mengendalikan stres yang muncul selama isolasi mandiri, sehingga ini juga perlu diatur.

Prinsip untuk aktivitas seksual dapat dilakukan adalah dengan kembali melihat rekomendasi melakukan aktivitas seksual selama pandemi (di atas).

Untuk pasangan yang berada di tempat yang sama:

1. Pasangan bisa dalam keadaan keduanya positif, atau salah satunya positif.

2. Aktivitas seksual bisa dilakukan untuk membuat rasa rileks, menenangkan, membahagiakan.

3. Jangan dipaksakan, perhatikan kondisi diri, jangan dilakukan jika masih ada gejala sakit yang tidak memungkinkan melakukan aktivitas seksual. 
4. Untuk yang pasangan sama-sama positif, lebih leluasa untuk melakukan hubungan seksual, tetapi sebaiknya tetap gunakan masker jika berhadapan.

5. Untuk pasangan yang salah satu saja yang positif, sebaiknya menunda aktivitas seksual.

6. Jika tetap juga ingin dilakukan, pastikan untuk hindari kontak mulut dan hidung. Hubungan seksual dengan posisi berhadapan harus tetap menggunakan masker.

7. Hubungan seksual dengan laki-laki dari belakang, lebih bebas, bisa tanpa masker, asal tidak melakukan ciuman, apalagi ciuman dalam.

8. Aktivitas seksual juga bisa dilakukan dengan saling bermasturbasi.

9. Lakukan seperlunya, tidak perlu berulang kali dalam sehari.

Sedangkan untuk pasangan yang tidak berada di tempat yang sama:

1. Pasangan bisa dalam keadaan keduanya positif, atau salah satunya positif.

2. Aktivitas seksual tetap bisa dilakukan untuk membuat rasa rileks, menenangkan, membahagiakan.

3. Jangan dipaksakan, lakukan saat diinginkan bersama pasangan.

4. Lakukan virtual sex. Bisa dengan sexting atau berkirim teks romantis, bisa lewat telepon, atau bisa menggunakan fasilitas videocall.

5. Aktivitas seksual yang bisa dilakukan adalah berfantasi seksual, hingga bermasturbasi. 
6. Tidak diharapkan untuk melakukan aktivitas ini dengan orang lain yang bukan pasangan.

7. Jika menggunakan alat bantu seksual, harus berhati-hati jangan sampai tidak dibersihkan sehingga dapat mengakibatkan infeksi di daerah kelamin.

8. Berhati-hati jika menggunakan fasilitas videocall, sebaiknya tidak melakukan perekaman untuk menghindari hal tidak diinginkan, seperti rekaman yang tersebar ke pihak luar.

9. Lakukan seperlunya, tidak perlu berulang kali dalam sehari.

Yang perlu dicatat adalah syarat hubungan seksual itu dapat berjalan dengan baik adalah diinginkan bersama, menyenangkan kedua pihak, dan tidak menimbulkan akibat buruk. Jika ini dipenuhi, dan dilakukan saat kondisi fisik sanggup melakukan hubungan seksual, terutama saat gejala dan keluhan selama isolasi mandiri sudah mereda, atau untuk mengatasi kejenuhan buat yang tanpa gejala sama sekali, tentu akan bermanfaat. Karena saat hubungan seksual dilakukan dengan baik dan memuaskan beberapa hormon seperti dopamin, serotonin, endorfin, dan oksitosin yang muncul akan membawa ketenangan, kesenangan, dan kebahagiaan. Sehingga daya tahan tubuh dapat terjaga selama isolasi mandiri.

\section{TAKE HOME MESSAGES}

Selama pandemi dan selama menjalankan isolasi mandiri tetaplah menjaga pola hidup dan gaya hidup sehat, sehingga kesehatan dan kebugaran terjaga dengan baik, yang akhirnya membuat fungsi seksual tetap baik, sehingga akan mendapatkan kepuasan seksual yang optimal, yang pada akhirnya membuat kualitas hidup yang maksimal. Juga lakukan kontrol keadaan kesehatan reproduksinya setelah selesai 
menjalankan isolasi mandiri. Jangan lupa tetap disiplin melakukan protokol kesehatan, walaupun telah menyelesaikan masa isolasi mandiri, dan lakukanlah vaksinasi untuk semakin memberi perlengkapan perlindungan. Buat diri sendiri dan juga buat orang lain. 


\section{DAFTAR PUSTAKA}

Elbert, H. 2021. Is It Safe to Have Sex During COVID-19 Self Isolation?. The Feed. March 22, 2021.

Farid, H. 2021. Being Sexually Frustated During Isolation. Harvard Health Publishing. January 12, 2021.

Leiya Y, 2021. Loneliness, Isolation, and Social Support Factors in COVID-19 Mental Health. Psychol Trauma. Epub. Jun 18, 2020.

Mollaioli, D., Sansone, A., Ciocca, G., Limoncin, E., Colonnello, E., Di Lorenzo, G., Jannini, A. Benefit of Sexual Activity on Psychological, relational, and Sexual Health During the COVID-19 Breakout. J Sex Med. Oct 16, 2020; 18:35-49.

NYC Health. Covid Sex Guide. NYC Health Department. June, 18, 2021.

Omar, SS., Dawood, W., Eid, N., Eldeeb, D., Munir, A., Arafat, W. Psychological and Sexual Health During the COVID-19 Pandemic in Egypt: Are Women Suffering More?. J Sex Med. Dec 1, 2020; 9:100295.

Pangkahila, W. 2021. Seks Yang Sehat di Masa Panemi. Presented at the Telekodina: Telekonseling Kesehatan Bagi Warga Yang Isoman. Bali, July 27, 2021.

Tribowo, JA., Tanojo, TD., Supardi, Pakpahan, C., Siswidiyanto, EB., Rezano, A., I'tishom, R. The Impact of the Coronavirus Disease19 Pandemic on Sexual Behavior of Marriage People in Indonesia. Maced J Med Sci. 2021 Jun 23; 9(A):440-445. 


\section{PERAWATAN DIRI PADA PASIEN COVID-19}

Desak Made Widyanthari, Putu Oka Yuli Nurhesti, Putu Ayu Asri

Damayanti

COVID-19 adalah penyakit menular yang disebabkan oleh virus corona SARS-CoV-2. Sebagian besar orang yang tertular COVID-19 akan mengalami gejala ringan hingga sedang, dan akan pulih tanpa penanganan khusus. Virus yang menyebabkan COVID-19 terutama ditularkan melalui percikan yang dihasilkan saat orang yang terinfeksi batuk, bersin, berbicara, atau mengembuskan nafas. Percikan yang berukuran sangat halus bisa melayang-layang di udara dalam jangka waktu lama dan terhembus jauh terutama di ruangan tertutup atau memiiliki ventilasi buruk. Percikan yang lebih besar yang dikenal dengan istilah droplet tidak bisa bertahan lama di udara, sehingga jatuh dan menempel pada lantai atau permukaan lainnya. Seseorang dapat beriksiko tertular menghirup udara yang mengandung virus dari percikan orang yang sudah terinfeksi COVID-19. Seseorang juga dapat tertular jika menyentuh permukaan benda yang terkontaminasi lalu menyentuh mata, hidung, atau mulut.

Jumlah individu yang terinfeksi COVID-19 semakin meningkat sehingga kapasitas Rumah Sakit untuk memberikan perawatan pada pasien semakin menurun. Pasien yang tidak bergejala atau bergejala ringan, dianjurkan untuk diberikan perawatan di rumah dengan tetap memonitor kondisinya secara mandiri dan melakukan pelaporan. Pemenuhan kebutuhan dasar manusia pada individu yang melakukan isolasi mandiri di rumah sangatlah penting dilakukan untuk menjamin kesejahteraan fisik dan psikologis pasien. Perawatan diri merupakan 
bagian penting dari kebuthan dasar yang perlu dipenuhi pada pasien yang melakukan isolasi mandiri di rumah.

Adapaun perawatan diri yang dibutuhkan pasien dapat dilakukan berdasarkan 14 kebutuhan dasar manusia menurut teori keperawatan Henderson.

\section{KEBUTUHAN BERNAFAS}

COVID-19 menyebabkan kerusakan paru yang bersifat akut maupun jangka panjang. COVID-19 menyebabkan komplikasi paru seperti radang paru (pneumonia) dan acute respiratory distress syndrome (ARDS) bahkan sepsis. Pada kondisi ini pasien akan merasakan kesulitan bernafas yang disertai batuk. Beberapa orang dapat sembuh dari kondisi pneumonia, namun gejala dapat juga menetap hingga beberapa bulan. Pasien umumnya membutuhkan oksigen bahkan ventilator untuk mempertahankan sirkulasi oksigen dalam tubuh.

Penting bagi pasien yang menjalani isolasi mandiri untuk memantau saturasi oksigen bila memiliki alat oximeter dirumah. Saturasi oksigen menunjukkan kadar oksigen dalam darah. Berikut adalah tingkat saturasi oksigen dan kaitannya dengan kondisi kesehatan. 
Tabel 12.1. Level Saturasi Oksigen

\begin{tabular}{|l|l|}
\hline Saturasi Oksigen & Intepretasi \\
\hline $95-100$ & Baik \\
\hline $93-94$ & $\begin{array}{l}\text { Perlu berbaring untuk meningkatkan kadar } \\
\text { oksigen }\end{array}$ \\
\hline$<92$ & Rujuk ke RS \\
\hline$<80$ & Memerlukan ventilator \\
\hline
\end{tabular}

Sumber: Kemenkes RI

Bila tidak memiliki alat oximeter, kita bisa memantau status pernafasan pasien berdasarkan respiration rate $(R R)$. Nilai $R R$ didapatkan dengan menghitung frekuensi napas selama satu menit. Jika $\mathrm{RR}>30 \mathrm{x} / \mathrm{mnt}$, maka pasien perlu dirujuk ke pelayanan kesehatan terdekat.

Beberapa upaya yang dilakukan untuk meningkatkan kapasitas pernafasan yaitu:

1. Latihan pursed-lip breathing; pasien menarik nafas melalui hidung selama beberapa detik dengan mulut tertutup, lalu hembuskan nafas perlahan dengan bibir mencucu selama 4-6 detik

2. Relaksasi dan turunkan bahu

3. Duduk tegak mampu meningkatkan ventilasi puncak dan mengurangi obstruksi jalan nafas

4. Mencondongkan tubuh ke depan dengan lengan menopang kursi atau lutut mempu meningkatkan kapasitas ventilasi

5. Proning position. Proning position dilakukan dengan posisi pasien berbaring tengkurap, seperti gambar di bawah. 


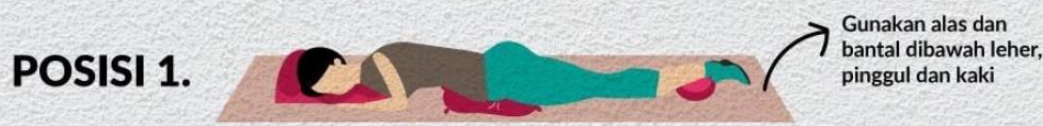

Berbaring di atas perut dalam 30 menit

POSISI 2.

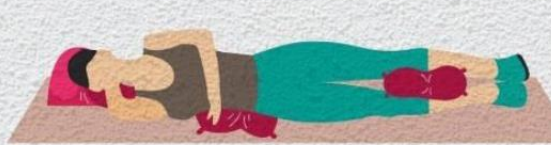

Gunakan alas dan bantal dibawah leher. pinggul dan dijepit

Berbaring ke sisi kanan dalam 30 menit

kedua kaki

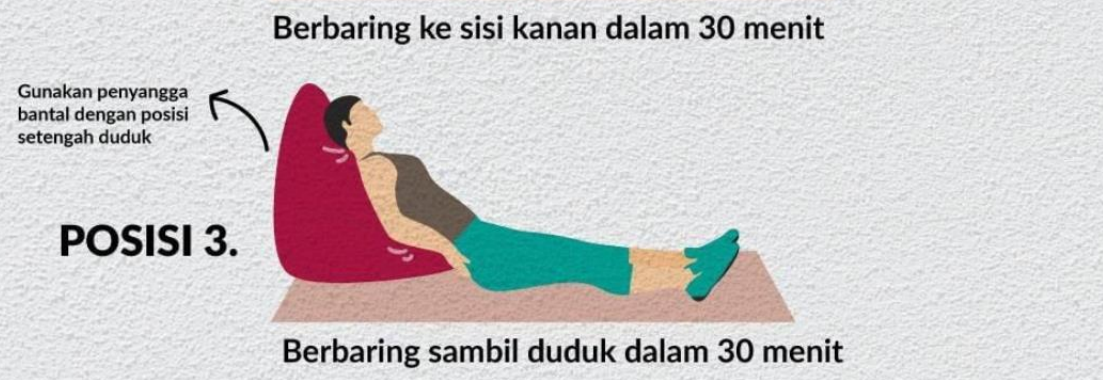

Gambar 12.1. Teknik pernapasan proning position. Sumber: Kemenkes RI

Irigasi hidung dengan normal saline direkomendasikan sebagai salah satu terapi nonfarmakologi untuk membersihkan rongga hidung. Pemberian normal saline $3 x$ sehari selama 8 minggu mampu mengurangi gejala infeksi saluran nafas atas. Pemberian nasal spray yang mengandung salin setiap hari juga mampu mengurangi gejala flu pada pasien dewasa.

Batuk juga merupakan keluhan yang sering dialami pasien COVID19. Berikut tips yang dapat dilakukan untuk meredakan batuk yang dialami: 
- Minumlah sepanjang hari dalam jumlah yang cukup. Hal ini tidak hanya membuat tenggorokan anda lembab dan nyaman, namun juga membantu anda tetap terhidrasi

- Minum minuman hangat, seperti teh atau rebusan jahe dan atau kunyit

- Minum satu sendok teh madu yang dicampurkan ke dalam teh hangat atau air hangat

- Bernafas dalam uap. Gunakan pancuran air hangat atau alat penguap, hal ini dapat membantu melegakan pernafasan

- Berkumur dengan air garam.

- Penggunaan mouthwash yang mengandung antimicrobial juga direkomendasikan untuk mengurangi viral load dalam rongga mulut

\section{KEBUTUHAN MAKAN DAN MINUM YANG ADEKUAT}

Mayoritas pasien COVID-19 menunjukkan gangguan dalam pemenuhan kebutuhan makan dan minum. Hal ini dapat disebabkan karena penurunan sensasi pengecap (ageusia) maupun penghidu (anosmia). Setiap hari sebaiknya kita secara teratur makan makanan yang mengandung tinggi protein, seperti; daging, telor, ikan, kacangkacangan, sayur dan buah-buahan, rendah garam, rendah lemak, dan rendah gula.

Beberapa pasien COVID-19 juga mengeluh merasa cepat kenyang, sering melewatkan waktu makan, hingga terjadi penurunan berat badan. Ketika terjadi penurunan nafsu makan, sebaiknya diet yang dianjurkan adalah diet tinggi energi protein atau sering disebut diet bergizi. Diet ini membantu untuk pemulihan diri dan mencegah 
penurunan berat badan lebih lanjut. Berikut beberapa tips yang dapat dilakukan untuk meningkatkan asupan makan dan cairan pada pasien COVID-19 selama manjalani isoman:

- Makan sedikit tapi sering, direkomendasikan 3 makan besar dan 2 snack/kudapan dalam sehari

- Makan dan minum dalam kondisi hangat

- Makan dan minum dalam posisi duduk

- Tetap duduk minimal 30 setelah makan

- Makan makanan bergizi

- Lakukan oral hygiene sebelum makan

- Dapatkan udara segar sebelum makan

- Beri makanan lunak bila mengalami kelelahan atau sulit bernafas

\section{KEBUTUHAN ELIMINASI}

COVID-19 dapat menyebabkan gangguan saluran cerna, seperti mual, muntah, dan diare. Hasil studi klinis menunjukkan kejadian diare dapat terjadi pada $2 \%-50 \%$ kasus pada pasien COVID-19. Pada pasien diare perlu dilakukan rehidrasi dan pemantauan kalium. Mikrobiota usus menjadi target terapi baru dan probiotik dapat berperan dalam pengelolaan pasien COVID-19. Komisi kesehatan nasional Cina merekomendasikan penggunaan probiotik untuk pengobatan pasien COVID-19 yang parah untuk menjaga keseimbangan usus dan mencegah infeksi bakteri sekunder. Hal yang dilakukan bila anda mengalami diare selama menjalani isolasi mandiri yaitu: 
- Tingkatkan asupan cairan

- Minum minuman rehidrasi oral, untuk mengganti cairan dan elektrolit yang hilang

- Makan porsi kecil namun sering

- Makan makanan tinggi kalium, seperti pisang atau kentang

- Hindari makan pedas, makanan penghasil gas seperti: buncis, kol, brokoli, paprika, jagung, kacang polong

- Hindari makanan berminyak dan berlemak

- Hindari makanan mengandung laktose seperti susu

- Hindari minuman yang mengandung kafein, alkohol dan minuman berkarbonasi

- Monitor tanda-tanda kekurangan cairan seperti: kencing berkurang, pusing, mulut kering, mata cekung, tidak keluar air mata saat menangis

- Konsultasikan ke dokter pemberian obat untuk mengatasi diare

\section{KEBUTUHAN BERGERAK DAN MEMPERTAHANKAN POSTUR TUBUH}

Aktivitas fisik merupakan salah satu komponen utama dari hidup sehat. Aktifitas fisik mampu mencegah dan mengurangi gejala dari penyakit kronik maupun infeksius, termasuk penyakit akibat virus COVID19. Aktifitas fisik akan mempengaruhi sistem imun. Untuk mendapatkan hasil maksimal aktifitas fisik diharapkan memenuhi prinsip latihan fisik, yaitu jenis latihan fisik, durasi, intensitas, maupun frekuansi latihan.

Pada pasien COVID-19 latihan fisik bersifat "individualized", disesuaikan dengan kondisi dan kemampuan individu masing-masing. Mulailah olahraga ringan jika anda tidak mengalami demam, tidak ada 
sesak napas, jantung berdebar atau nyeri dada saat berjalan serta tidak ada pembengkakan kaki. Latihan fisik dapat dilakukan secara bertahap, disesuaikan dengan kemampuan individu masing-masing. Mulai dari latihan fisik ringan seperti berjalan $3 x$ seminggu. Hindari kelelahan akibat olahraga. Lakukan istirahat setelah olahraga minimal 1x24 jam. Aktifitas fisik harus dihentikan atau segera mencari pertolongan jika muncul keluhan atau gejala seperti nyeri dada, sesak, dada berdebar, kelelahan, pusing atau nyeri kepala ringan, keluar keringat dingin, kulit pucat dan warna bibir kebiruan. Bila pasien isoman memiliki komorbid tertentu sebaiknya program latihan dikonsultasikan ke dokter terlebih dahulu.

\section{KEBUTUHAN TIDUR DAN ISTIRAHAT}

Tidur sangat penting untuk kesehatan fisik dan meningkatkan sistem kekebalan tubuh. Tidur juga berperan dalam menjaga stabilitas kesehatan emosional dan mental, mengurangi stress, depresi maupun kecemasan. Pandemi COVID-19 yang berdampak pada semua sektor menimbulkan konsekunsi secara ekonomi, mental dan emosional sehingga menimbulkan gangguan tidur yang cukup signifikan. Pasien yang menjalani isolasi mandiri dapat mengalami kesedihan bahkan depresi yang berpotensi menyebabkan masalah tidur. Beberapa hal yang bisa dilakukan untuk meningkatkan kualitas dan kuantitas tidur, yaitu:

- Buat jadwal tidur yang teratur, meskipun saat hari libur

- Lakukan persiapan sebelum tidur, seperti membaca ringan, peregangan dan meditasi

- Matikan lampu atau gunakan lampu tidur

- Hindari makan sebelum tidur

- $\quad$ Sering ganti sprei dan merapikan tempat tidur 
- Hindari menggunakan perangkat elektronik seperti ponsel, tablet, laptop 1 jam sebelum tidur

- Batasi tidur siang 10-20 menit agar tidak mengganggu tidur malam.

- Rutin melakukan aktivitas fisik

- Gunakan Teknik relaksasi, misalnya mendengarkan musik nafas dalam, peregangan, mendengarkan musik yang menenangkan, memberikan aromaterapi dalam kamar jika perlu.

- Batasi pencarian informasi tentang COVID-19 terutama di media sosial, cukup melihat satu atau dua situs terpercaya dan baca dalam beberapa waktu yang terbatas

- Jaga pola makan yang sehat, kurangi asupan alkohol dan kafein

\section{KEBUTUHAN BERPAKAIAN}

Manusia membutuhkan pakaian untuk melindungi dan menutup dirinya, dimana pada perkembangan selanjutnya pakaian juga digunakan sebagai simbol status, jabatan, ataupun kedudukan seseorang yang memakainya. Pakaian dapat meningkatkan keamanan selama kegiatan tertentu yang dapat membahayakan tubuh. Pakaian juga memberikan perlindungan pada badan dari paparan toksin dan mikroorganisme. Salah satu tujuan utama dari pakaian adalah untuk menjaga pemakainya merasa nyaman. Beberapa hal terkait pakaian yang perlu diperhatikan pada pasien COVID-19 dengan isolasi mandiri adalah:

- Berpakaian yang nyaman, bersih dan rapi merupakan perawatan diri yang perlu diperhatikan pada pasien COVID-19 yang isolasi mandiri di rumah. 
- Pakaian yang digunakan hendaknya berbahan katun dan mudah menyerap keringat, nyaman dan tidak terlalu ketat.

- Berganti pakaian dilakukan minimal 1 kali sehari pada pasien isolasi mandiri.

- Pakaian pasien bisa dicuci dengan deterjen dan dijemur. Baik pakaian kotor maupun pencucian pakaian dilakukan terpisah dengan pakaian anggota keluarga yang sehat. Saat mencuci pakaian penderita maka keluarga harus menggunakan masker dan dicuci dengan air hangat atau pakaian didiamkan terlebih dahulu beberapa hari sebelum dicuci.

\section{MEMPERTAHANKAN SUHU TUBUH}

Demam dapat terjadi pada pasien COVID-19. Karakteristik demam sangat variatif, ada yang mengeluh hanya mengalami demam ringan dan sedang, namun ada juga mengeluh demam tinggi. Seseorang dikatakan mengalami demam jika suhu tubuh $>37,5^{\circ} \mathrm{C}$. Demam dapat dimulai dari hari ke-2 hingga 2 minggu setelah terpapar virus. Selain pemberian obat penurun panas, berikut perawatan diri yang dilakukan bila anda mengalami demam:

- Tingkatkan asupan cairan

- Monitor pengeluaran urin

- Gunakan pakaian longgar dan menyerap keringat

- Ganti sprei bila basah kena keringat

- Lakukan kompres dengan kain/washlap yang sebelumnya direndam dalam air hangat pada dahi, leher, dada, ketiak kanankiri, abdomen dan pangkal paha kanan-kiri. Basahi kain bila telah kering. 
- Isirahat yang cukup

\section{MENJAGA TUBUH TETAP BERSIH DAN MELINDUNGI KULIT}

Menjaga kebersihan diri merupakan hal yang sangat penting terutama untuk menjaga diri individu tetap sehat, dan mengurangi risiko diri maupun orang terdekat tertular penyakit. Banyak penyakit yang tersebar saat mikroorganisme tersebar dari satu individu ke individu yang lain melalui kontak langsung, seperti bersentuhan dengan orang yang terinfeksi, atau kontak tidak langsung, seperti menyentuh suatu barang yang telah disentuh oleh orang yang terinfeksi. Kebersihan diri tidak hanya penting bagi individu yang sakit, namun juga bagi orang di sekitarnya. Kebersihan diri seseorang dapat berdampak pada bagaimana cara orang lain melihat dan memperlakukan individu, sehingga dapat dikatakan bahwa hal ini bisa membantu pasien untuk meningkatkan kepercayaan diri.

Pasien dengan isolasi mandiri tetap memerlukan kebersihan diri dan menjaga tubuh tetap terawatt dan kulit tetap sehat. Personal hygiene yang baik diperlukan saat perawatan pasien di rumah yaitu:

- Mandi dengan sabun dan air bersih 2 kali sehari, bisa menggunakan air hangat

- Pisahkan peralatan mandi seperti sabun, pasta gigi, handuk, sisir dan barang pribadi lainnya untuk individu yang sehat dan yang sakit

- Gunakan kamar mandi yang berbeda dengan anggota keluarga yang lain, atau jika kamar mandi hanya satu gunakan dengan 
jarak 1-2 jam dari anggota keluarga yang lain, semprotkan desinfektan setelah pemakaian oleh Individu yang sakit dan sebelum pemakaian oleh bindividu yang sehat

- Gosok gigi minimal dua kali sehari, gunakan sikat gigi yang lembut

- Bersihkan organ reproduksi dengan benar

- Mencuci rambut dua hari sekali dengan shampo dan air bersih

- Mencuci tangan dengan benar

- Memotong kuku agar tetap pendek dan bersih

- Menjaga dan rajin mengamati kondisi kulit

- Memakai lotion agar kulit tetap lembab dan sehat

\section{MENGHINDARI BAHAYA LINGKUNGAN DAN MENGHINDARI CEDERA}

Keamanan merupakan keadaan bebas dari cedera fisik dan psikologis atau bisa juga diartikan sebagai suatu keadaan aman dan tentram. Individu yang merasa tidak aman akan mengalami sensasi yang tidak menyenangkan. Kebutuhan akan keselamatan atau keamanan adalah kebutuhan untuk melindungi diri dari bahaya fisik. Ancaman terhadap keselamatan seseorang dapat dikategorikan sebagai ancaman mekanis, kimiawi, retmal dan bakteriologis. Kebutuhan akan keaman terkait dengan konteks fisiologis dan hubungan interpersonal. Keamanan fisiologis berkaitan dengan sesuatu yang mengancam tubuh dan kehidupan seseorang. Ancaman itu bisa nyata atau hanya imajinasi seperti penyakit, nyeri, cemas, dan sebagainya. Cedera merupakan rusaknya struktur dan fungsi anatomis yang diakibatkan oleh keadaan patologis. Selain itu cedera juga dapat diartikan sebagai kerusakan fisik 
yang terjadi pada manusia yang secara tiba-tiba mengalami penurunan energi dalam jumlah yang melebihi ambang batas toleransi fisiologis

- . Lingkungan yang aman dan nyaman sangat diperlukan oleh pasien yang melaklukan isolasi mandiri akibat infeksi virus COVID-19. Lingkungan ini meliputi lingkungan fisik dan psikologis pasien. Lingkungan fisik yang sehat membantu meningkatkan sistem imun pasien dan mempercepat penyembuhan. Lingkungan psikologis yang baik menjadi dukungan pasien untuk melakukan berbagai aktivitas yang akan mendukung penyembuhan. Hal-hal yang bisa dilakukan saat pasien isolasi mandiri di rumah adalah:

- Menjaga suhu dan ventilasi ruangan tetap baik

- Pencahayaan ruangan baik

- Tidak menaruh benda-benda berbahaya di kamar tempat isolasi pasien

- Membawakan alat-alat yang diperlukan pasien selama isolasi mandiri

- Menjaga kondisi kantai tetap bersih dan tidak licin

- Memenuhi kebutuhan rasa aman dan nyaman pasien

- Memberikan informasi yang benar tentang COVID-19 dan tidak menakut nakuti pasien

- Mencegah agar pasien tidak jatuh

- Memberikan dukungan fisik dan psikologis pada pasien

- Jika perlu memasang kamera pengawas di kamar pasien yang dapat terhubung dengan anggota keluarga yang lain 


\section{KEBUTUHAN BERKOMUNIKASI}

Komunikasi merupakan kebutuhan yang sangat mendasar dalam kehidupan manusia. Komunikasi dengan orang lain penting agar dapat mengungkapkan perasaan emosi, kebutuhan, ketakutan atau pendapat. Bahkan komunikasi telah menjadi suatu fenomena bagi terbentuknya suatu masyarakat atau komunitas yang terintegrasi oleh informasi, dimana masing-masing individu dalam masyarakat itu sendiri saling berbagi informasi untuk mencapai tujuan bersama. Secara sederhana komunikasi dapat terjadi apabila ada kesamaan antara penyampai pesan dan orang yang menerima pesan. Komunikasi dilakukan dengan sengaja oleh seseorang untuk menyampaikan pesan kepada orang lain demi memenuhi kebutuhannya, seperti membujuk atau menjelaskan. Komunikasi sebagai proses satu arah dapat berbentuk Bahasa non verbal seperti; mimik muka, nada suara, gerakan tubuh dan sebagainya yang dilakukan secara spontan.

Dalam kehidupan sehari-hari, komunikasi sering dilakukan yang merupakan kebutuhan yang mendasar bagi setiap manusia. Komunikasi secara lisan terjadi pada saat seseorang dengan orang lain saling menyampaikan pesan/berdekatan, tetapi apabila berada dalam jarak yang jauh dapat dilakukan dengan menggunakan beberapa cara untuk berkomunikasi. Komunikasi berarti milik bersama atau membagi merupakan suatu proses yang bertujuan untuk membangun pengertian dan kebersamaan sedangkan secara terminologis, kata komunikasi merujuk pada proses penyampaian suatu pernyataan oleh pihak satu kepada pihak lain. Pengertian komunikasi merupakan suatu proses ketika seseorang dengan orang lain saling menyampaikan informasi dari satu pihak ke pihak lain/banyak pihak agar dapat terhubung dengan 
lingkungan sekitarnya. Komunikasi terjadi dalam penerimaan dan pengiriman berbagai informasi organisasi dalam kelompok formal maupun informal dari suatu organisasi. Selain itu, jenis komunikasi ini banyak dari tiap individunya yang memberikan pendapat yang berbeda, karena informasi yang disampaikan dari masing-maing individu memiliki makna yang berbeda.

Komunikasi yang baik diperlukan saat pasien dinyatakan positif COVID-19 dan harus menjalani isolasi mandiri. Pemisahan kamar, kamar mandi, alat makan dll dapat menimbulkan perasaan tidak nyaman dan pasieb merasa dikucilkan. Beberapa hal yang dapat dilakukan untuk membangun komunikasi dengan pasien adalah isolasi mandiri adalah:

- Komunikasikan bahwa pasien akan dirawat oleh anggota keluarga yang paling sehat dan tidak memiliki komorbid tertentu

- Fasilitasi keperluan komunikasi pasien seperti hand phone/mobile phone, paket internet, televisi, radio dll

- Melakukan komunikasi secara virtual dengan orang-orang yang berarti bagi pasien bisa dengan video call atau menggunakan platform tertentu yang sudah disepakati

- Pahami bahasa komunikasi non verbal pasien

- Berikan pasien kesempatan untuk mengkomunikan perasaan, ketakutan, pendapat dan perasaan emosi

- Gunakan bahasa yang singkat dan mudah dipahami pasien

- Kirim emoticon atau reaction yang menunjukkan bahwa seluruh anggpota keluarga menyayangi pasien

- Atasi ketakutan, kecemasan dan perasaan stress pasien 
- Fasilitasi pasien untuk bisa berkomunikasi dengan tenaga kesehatan melalui telekonseling

\section{BERIBADAH SESUAI KEYAKINAN SESEORANG}

Kebutuhan spiritual adalah harmonisasi dimensi kehidupan dalam menemukan arti, tujuan, menderita, dan kematian; kebutuhan akan harapan dan keyakinan hidup, dan kebutuhan akan keyakinan pada diri sendiri, dan Tuhan. Spiritualitas merupakan konsep yang kompleks dan unik, dimana setiap individu memiliki spiritualitas yang berbeda sehingga dapat dikatakan bahwa spiritualitas adalah karakteristik sifat manusia. Kesejahteraan spiritual yang tercapai dapat menciptakan kesehatan spiritual, dimana individu yang merasa sehat secara spiritual ditandai dengan gembira, mudah untuk memaafkan, ikhlas, mengalami peningkatan kualitas hidup, dan pemahaman terkait kesejahteraan fisik dan emosial yang dimilikinya bersifat positif.

Pasien positif COVID-19 yang melaklukan isolasi mandiri tetap dapat beribadah sesuai dengan agama dan kepercayaan masing-masing dengan ketentuan sebagai berikut:

- Sembahyang dan berdoa sebaiknya dilakukan dari kamar pasien agar mengurangi kontak dengan anggota keluarga yang sehat dan menghindari pemakaian sarana peribadatan secara bersama-sama

- Sediakan segala sarana yang diperlukan pasien

- Berikan pasien motivasi untuk mendekatklan diri pada Tuhan agar memperoleh kesembuhan dengan tetap berusaha melakukan terapi sesuai dengan anjuran tenaga Kesehatan 
- Jika memerlukan kehadiran atau nasehat tokoh agama atau spiritual dapat dihadirkan atau dilakukan secara virtual

- Sediakan buku-buku keagamaan, gambar-gambar dan videovideo tentang spiritualitas

\section{KEBUTUHAN BEKERJA}

Bekerja adalah suatu bentuk aktivitas atau kegiatan yang melibatkan kesadaran manusia untuk mencapai hasil yang sesuai dengan harapannya serta mendapat penghargaan baik dalam bentuk material non material. Bekerja memerlukan kesadaran akan aktivitas dan tujuan yang diinginkan. Bekerja melibatkan beberapa aspek, meliputi aspek kesadaran, dilakukan dengan terencana, ada hasil yang didapatkan, dan melibatkan aspek kepuasan. Tujuan dari bekerja adalah untuk memenuhi kebutuhan hidup manusia, mendapatkan rasa aman, mencari kepuasan, dan mengaktualisasikan dirinya dalam bekerja. Bekerja dapat menjadi suatu terapi bagi individu yang sakit.

- Pasien yang menjalani isolasi mandiri akibat infeksi COVID-19 masih bisa melakukan beberapa pekerjaan secara online atau bekerja dari rumah dengan ketentuan sebagai berikut:

- Bekerja dilakukan secara online atau dari rumah

- Pekerjaan yang dilakukan adalah yang sifatnya ringan dan tidak terlalu menguras pikiran

- Bekerja tidak lebih dari 3-5 jam sehari

- Bekerja dilakukan pada siang hari dan tidak begadang bekerja pada malam hari 
- Bekerja sesuai kemampuan fisik pasien dengan tetap mengutamakan waktu tidur dan istirahat serta mengutamakan penyembuhan dari COVID-19

- Keikutsertaan pasien secara online dalam kegiatan bekerja merupakan salah satu bentuk terapi untuk mengurangi kecemasan pada pasien dan meningkatkan perasaan berharga

\section{KEBUTUHAN AKAN HIBURAN ATAU REKREASI}

Rekreasi merupakan salah satu kebutuhan dasar manusia dimana seseorang mendapatkan kebahagiaan dan kesehatan fisik dan jiwa melalui rekreasi. Rekreasi bermanfaat dalam kehidupan manusia, baik untuk melepas lelah maupun untuk mencari suasana berbeda dari kegiatan sehari-harinya. Rekreasi diartikan sebagai penyegaran kembali badan dan pikiran; sesuatu yang menggembirakan hati dan menyegarkan seperti hiburan, piknik. Pemenuhan kebutuhan rekreasi dapat meningkatkan kreativitasnya individu, menambah pengetahuan, mendapatkan kepuasan serta kebahagiaan. Dalam melakukan rekreasi seseorang dapat memilih rekreasi sesuai dengan yang diinginkan atau yang dibutuhkan. Rekreasi yang dapat dilakukan seseorang antara lain rekreasi edukatif, rekreasi kultural, dan lain-lain. Kebutuhan rekreasi dipengaruhi oleh beberapa faktor antara lain: sosial ekonomi, jenis kelamin, usia dan keluarga, ketersediaan waktu luang dan juga faktor pengetahuan.

Rekreasi dan bermain merupakan kebuthan dara manusia yang sangat penting dipenuhi pada pasien Covod 19 yang melakukan isolasi mandiri, Beberapa hal yang dapat dilakukan antara lain: 
- Mengajak pasien bermain secara virtual terutama jika pasiennnya adalah anak-anak

- Melakukan permainan berkelompok dan sifatnya online

- Menyediakan kamar yang dekat dengan jendela agar sirkulasi di ruangan lancar, mendapat sinar matahari, dan- pasien masih bisa melihat pemandangan di sekitarnya

- Melakukan wisata virtual dengan melihat foto atau gambar atau video tempat wisata tertentu yangh disukai pasien

- Menayangkan hiburan atau menonton film kesukaan pasien, lagu kesukaan pasien atau tontonan lain yang disukai seperti humor atau acara yang dapat membangkitkan tawa pasien dan membuat pasien gembira

- Kebutuhan ini juga dapat dipenuhi dengan melakukan olahraga ringan dan kegiatan relaksasi seperti meditasi dan yoga

\section{KEBUTUHAN BELAJAR DAN MEMPEROLEH INFORMASI}

Pasien yang terinfeksi COVID-19 pada akhirnya akan memperoleh pembelajaran tentang penyakit ini melalui pengalaman pribadi. Beberapa hal yang dapat dipelajari pasien dan dapat dijadikan dasar untuk mengedukasi orang lain serta mencegah infeksi yang sama di masa depan adalah:

- Mengamati reaksi tubuh terhadap tiap tahapan dari infeksi virus COVID-19 ini

- Belajar tentang penyakit infeksi COVID-19 yang dialami mulai dari proses penyakit dan cara-cara yang dapat dilakukan untuk 
mempercepat pemulihan misalya nutrisi yang berkualitas, manajemen stress, perbaikan sistem imun dll

- Belajar untuk menerima keterbatasan diri

- Belajar merawat diri sendiri

- Keluarga dapat belajar untuk merawat anggota keluarga dengan penyakit menular dan memenuhi kebutuhannya

- Keluarga dapat menyediakan sumber informasi penting dan terpercaya terkait penyakit dan membantu pasien menyaring informasi yang didapatkan

- Seluruh anggota keluarga akan belajar lebih waspada terhadap infeksi yang sama di masa yang akan dating

- Pasien dan keluarga dapat meminta edukasi dari tenaga kesehatan secara virtual.

\section{DAFTAR PUSTAKA}

Al-Tawfiq JA, Abdrabalnabi R, Taher A, Mathew S, Rahman KA. 2019. Infection control influence of Middle East respiratory syndrome coronavirus: A hospital-based analysis. Am J Infect Contr, 47:431e4

Chan JF, Yuan S, Kok KH, To KK, Chu H, Yang J, et al. 2020. A familial cluster of pneumonia associated with the 2019 novel coronavirus indicating person-to-person transmission: a study of a family cluster. Lancet. https://doi.org/10.1016/s0140-6736(20) 30154-9.

Casale, M., Rinaldi, V., Sabatino, L., Moffa, A., \& Ciccozzi, M. 2020. Could nasal irrigation and oral rinse reduce the risk for COVID-19 infection? International Journal of Immunopathology and Pharmacology, 34 , $1-3$. https://doi.org/10.1177/2058738420941757 
D'Amico, F., Baumgart, D. C., Danese, S., \& Peyrin-Biroulet, L. 2020. Diarrhea During COVID-19 Infection: Pathogenesis, Epidemiology, Prevention, and Management. Clinical Gastroenterology and Hepatology, 18(8), 1663-1672. https://doi.org/10.1016/j.cgh.2020.04.001

da Silveira, M. P., da Silva Fagundes, K. K., Bizuti, M. R., Starck, É., Rossi, R. C., \& de Resende e Silva, D. T. 2021. Physical exercise as a tool to help the immune system against COVID-19: an integrative review of the current literature. Clinical and Experimental Medicine, 21(1), 15-28. https://doi.org/10.1007/s10238-020-00650-3

Excellence, C., England, N. H. S., \& Improvement, N. H. S. 2020. Managing COVID-19 symptoms (including at the end of life) in the community: Summary of NICE guidelines. The BMJ, 369(April), 14. https://doi.org/10.1136/bmj.m1461

Gao, Q. Y., Chen, Y. X., \& Fang, J. Y. 2020. 2019 Novel coronavirus infection and gastrointestinal tract. Journal of Digestive Diseases, 21(3), 125-126. https://doi.org/10.1111/1751-2980.12851

Kementrian Kesehatan RI. 2020. Pedoman Pencegahan dan Penanganan COVID-19

Medicine, P., Pm, R., \& Service, R. 2020. Home Rehabilitation Program for COVID-19 Patients. 1-20.

Potter and Perry. 2010. Fundamental Keperawatan Buku 1. Edisi 7. Jakarta: EGC

Rosdahl Cb \& Kowalski Mt. 2012. Textbook of Basic Nursing. Lww: Philadephia 
Rehman, A. 2021. Sleep Guidelines during the COVID-19 Pandemic. https://www.sleepfoundation.org/sleep-guidelines-COVID-19isolation. Diakses 26 Juli 2021

Šlapak, I., Skoupá, J., Strnad, P., \& Horník, P. 2008. Efficacy of isotonic nasal wash (seawater) in the treatment and prevention of rhinitis in children. Archives of Otolaryngology - Head and Neck Surgery, 134(1), 67-74. https://doi.org/10.1001/archoto.2007.19

Suherman, A. 2020. Buku Ajar Teori-teori Komunikasi. Yogyakarta : Deepublish.

Suryandartiwi, W. 2021. Dasar-dasar Komunikasi Kesehatan. Sumatra Barat: Mitra Cendekia Media

Tano, L., \& Tano, K. 2004. A daily nasal spray with saline prevents symptoms of rhinitis. Acta Oto-Laryngologica, 124(9), 1059-1062. https://doi.org/10.1080/00016480410017657

WHO. 2020. Coronavirus Disease 2019 (COVID-19). WHO; 2020. Situation Report 23.

WHO. 2020. Mental Health and Physical Consideration during the COVID-19 Outbreak. WHO 2020 


\section{SERBA-SERBI ISOLASI MANDIRI PADA LANJUT USIA YANG TERINFEKSI COVID-19}

I Gusti Putu Suka Aryana, I Made Kristya Permana, RA Tuty Kuswardhani

\section{MENGAPA LANSIA RENTAN TERHADAP COVID-19?}

Menurut WHO, individu dari segala usia dapat dengan mudah terinfeksi oleh COVID-19, namun orang lanjut usia dan orang dengan kondisi medis yang sudah ada sebelumnya (seperti asma, diabetes, tekanan darah tinggi, dan penyakit jantung) lebih rentan mengalami sakit parah akibat COVID-19. Seiring bertambahnya usia, sistem kekebalan tubuh akan melemah. Ini membuat lansia lebih rentan terhadap semua jenis infeksi. Pada lansia, infeksi virus ini dapat menimbulkan gejala yang lebih parah dibandingkan dewasa muda atau anak-anak. Meski kebanyakan orang yang terinfeksi hanya mengalami gejala ringan, pada lansia penyakit ini bisa berujung pada kematian.

Kematian terbanyak terjadi pada pasien COVID-19 lanjut usia, data dunia menunjukan 8 dari 10 lansia yang terkena COVID-19 mengalami kematian, sedangkan data di Indonesia lanjut usia memiliki angka kematian $57 \%$. Hal ini dikarenakan sistem pertahanan tubuh dan sistem organ pada lansia tidak sebaik saat masih muda. Selain itu, adanya penyakit yang sering menyerang lansia seperti diabetes atau penyakit jantung, dapat memperlambat penyembuhan atau meningkatkan risiko komplikasi dari penyakit ini.

Pada lanjut usia (lansia) sel-sel tubuh yang menua mengalami proses yang disebut "peradangan penuaan", di mana sel-sel menjadi 
terkunci dalam keadaan peradangan kronis derajat rendah akibat penuaan. Kondisi ini menyebabkan sistem kekebalan tubuh lansia kesulitan dalam mengendalikan virus pada awalnya, dan virus menjadi lebih mudah berkembang biak dengan cepat. Lansia akan mengalami peradangan yang terlalu agresif di kemudian hari akibat akumulasi proses peradangan. Bahkan saat "jumlah virus" mulai menurun, sistem kekebalan akan terus mengeluarkan protein peradangan yang mengakibatkan "badai radang" pada lansia.

Selain alasan di atas, lansia juga memiliki tantangan isolasi atau mobilitas. Jadi karena mereka terisolasi, mereka tidak bisa mendapatkan informasi tentang apa yang harus dilakukan, atau mereka tidak bisa mendapatkan makanan yang mereka butuhkan jika keadaan menjadi lebih sulit. Di banyak masyarakat, lansia lebih cenderung hidup dalam kemiskinan, yang membuat mereka lebih sulit mendapatkan hal-hal yang mereka butuhkan dan mengurus diri mereka sendiri. Kemiskinan menghadirkan berbagai tantangan yang berkaitan dengan kesehatan. Apalagi pada masa pandemi ini salah satu langkah strategis dalam pencegahan COVID-19 adalah menjaga jarak dan berdiam diri di rumah, Banyak orang salah memahami hal tersebut sehingga yang terjadi adalah kelompok lansia mengalami "isolasi sosial”. Padahal menjaga jarak fisik tidak harus berarti mengasingkan lansia karena isolasi sosial dapat berdampak negatif pada kekebalan dan kesehatan mental lansia. Kuncinya adalah komunikasi - banyak lansia tidak memiliki alat komunikasi dan tidak memiliki akses terhadap informasi. Keluarga perlu memastikan kondisi lansia dengan menelepon secara teratur untuk membantu memerangi isolasi sosial. Selain itu pada lansia yang mengalami demensia (pikun) atau gangguan kognitif akan sulit untuk mengikuti protokol kesehatan untuk mengurangi risiko terkena COVID- 
19, atau mengutarakan kondisi yang dialaminya. Hal ini terutama ketika lansia memiliki kapasitas terbatas untuk berkomunikasi secara verbal atau mengungkapkan rasa sakit dan ketidaknyamanan. Dengan demikian keluarga harus lebih aktif dalam mengenali keluhan, perubahan dan kondisi yang mengancam jiwa pada lansia,

Selain itu ketakutan dan kepanikan yang disebabkan oleh COVID19 menjamur lebih cepat daripada pandemi itu sendiri. Ketakutan yang berlebihan terhadap COVID-19 menambah masalah yang sering dihadapi oleh lansia seperti sulit tidur dan kurangnya aktifitas fisik. Sehingga lansia akan mengalami kondisi depresi, penarikan diri dan keengganan. Kondisi kelemahan fisik ditambah masalah kesehatan mental akan menambah risiko perburukan lansia dalam kualitas hidupnya. Apalagi pada banyak kasus, lansia yang memiliki kondisi medis sebelumnya seperti masalah jantung, diabetes dan ginjal akan menahan diri untuk mengunjungi pusat layanan kesehatan. Hal tersebut menyebabkan terputusnya pengobatan yang dibutuhkan sehingga tidak jarang lansia harus dilarikan ke rumah sakit akibat penyakit yang dialami sebelumnya kambuh dan menjadi lebih parah. Hal ini diperparah dengan penuhnya pusat pusat layanan kesehatan akibat lonjakan kasus COVID19 yang dapat menunda tatalaksana yang dibutuhkan oleh lansia.

Dengan demikian dapat disimpukan bahwa lansia menjadi rentan terhadap COVID-19 karena adanya kondisi fisik yang mengalami penurunan, penyakit yang dimiliki sebelumnya dan masalah kesehatan mental dalam menghadapi pandemi ini. Daya tahan tubuh yang lemah ditambah depresi yang ditimbulkan oleh isolasi sosial dan ketakutan terhadap COVID-19 akan menurunkan kualitas hidup lansia di era pandemi ini. Sebagai kelompok yang paling rentan maka lansia perlu 
mendapat perhatian khusus agar kerentanan tersebut tidak menjadi stigma yang malah menyebabkan kelompok ini malah mengalami diskriminasi bahkan penelantaran dalam menghadapi COVID-19.

\section{USAHA UNTUK MENJAGA LANSIA DARI TERINFEKSI COVID-19}

Berikut adalah beberapa cara yang dapat dilakukan untuk mengurangi resiko lansia terpapar COVID-19

\section{Jaga kesehatan diri dan lingkungan sekitar}

Menjaga kesehatan pribadi merupakan hal pertama yang dilakukan untuk mencegah lansia terkena COVID-19. Dua hal yang utama adalah memakai masker dan mencuci tangann. Saat harus pergi ke luar rumah dan berinteraksi dengan lansia kenakan masker serta menjaga jarak setidaknya 1 meter dari orang lain. Cuci tangan sesering mungkin dengan sabun dan air mengalir, serta meningkatkan daya tahan tubuh dengan mengonsumsi makanan sehat dan rutin berolahraga. Selain itu, secara rutin membersihkan barang-barang di dalam rumah yang sering disentuh oleh penghuni rumah, misalnya gagang pintu atau telepon. Vaksinasi anggota keluarga juga merupakan cara dalam mencegah penularan. Dengan anggota keluarga yang sudah tervaksinasi, maka akan membentuk lingkungan yang imun pada skala rumah tangga, yang mencegah lansia, terutama yang tidak layak vaksin, dari terpapar virus COVID-19.

\section{Jaga kesehatan lansia dengan nutrisi dan aktivitas fisik}

Jaga kesehatan lansia dengan memberikan asupan nutrisi yang seimbang dan higienis. Pilih makanan yang mengandung protein, lemak 
baik, karbohidrat kompleks, serat, serta vitamin dan mineral. Selain sebagai sumber energi, makanan sehat juga memperkuat sistem imun lansia.

Lansia yang masih mampu aktif disarankan melakukan kegiatan sehari-hari secara mandiri. Selain itu lansia juga perlu untuk melakukan latihan fisik ringan atau peregangan otot setidaknya 20-30 menit setiap hari. Latihan fisik yang dilakukan bersifat individual disesuaikan dengan kemampauan lansia. Latihan fisik sebaiknya dilakukan sambil berjemur di sinar matahari pagi.

Lansia yang memiliki penyakit kronis yang dapat menurunkan daya tahan tubuh seperti diabetes mellitus, sebaiknya meneruskan obatobatan yang rutin digunakan sebagai upaya untuk mengontrol penyakit kronis yang diderita.

\section{Batasi bepergian ke luar rumah}

Selama masa pandemi COVID-19 seperti saat ini, semua orang dianjurkan untuk tetap berada di rumah kecuali untuk membeli bahan makanan atau ada keperluan mendesak, misalnya mencari pertolongan medis yang darurat. Walaupun lansia di rumah masih bugar dan aktif, tetap batasi mereka untuk bepergian, apalagi berkumpul dengan orang lain. Alasannya, risiko terinfeksi di tempat yang banyak orang jauh lebih besar dibandingkan di rumah. Bila lansia di rumah memiliki penyakit yang perlu rutin minum obat dan kontrol ke dokter, jangan lupa mengingatkannya untuk minum obat secara rutin sesuai anjuran dokter. Namun, selama keadaannya baik-baik saja, tunda dulu kontrol rutin ke dokter untuk sementara waktu. Bila memang membutuhkan konsultasi dengan dokter, lakukan secara online melalui aplikasi kesehatan. 


\section{Terapkan menjaga jarak}

Selama di dalam rumah, physical distancing (menjaga jarak) tetap penting untuk diterapkan. Batasi kunjungan orang-orang yang biasa datang ke rumah untuk bertemu lansia. Selain itu, sesama penghuni rumah pun sebaiknya menjaga jarak selama menemui lansia, terutama bila sedang sakit. Namun jangan sampai hal ini membuat lansia merasa dijauhi dan terasing dari orang lain. Mereka tetap boleh melakukan interaksi dengan penghuni rumah yang lain melalui teknologi seperti video call atau pesan teks.

\section{Vaksinasi COVID-19}

Vaksinasi COVID-19 sangat penting pada lansia. Tujuan utama vaksinasi COVID-19 adalah mengurangi transmisi/penularan COVID-19, menurunkan angka kesakitan dan kamatian akibat COVID-19. Mencapai kekebalan kelompok di masyarakat (herd imunity) dan melindungi masyarakat dari COVID-19 agar tetap produktif secara sosial dan ekonomi. Perhatian khusus pada lansia dengan kerentaan (misalnya lansia yang menggunakan kursi roda, atau yang terbaring di tempat tidur), setiap kejadian ikutan produk farmasi termasuk vaksin dapat memperburuk perjalanan atau kondisi penyakit aslinya. Manfaat dan risiko menerima vaksin pada kelompok lansia ini harus dievaluasi secara terpisah dengan menghadiri dokter dan penilaian klinis tersebut harus dilakukan dengan lebih hati-hati.

\section{ISOLASI MANDIRI PADA LANSIA YANG TERINFEKSI COVID-19}

Pasien lanjut usia (lansia) yang terinfeksi virus COVID-19 tidak selalu harus dirawat dirumah sakit. Lansia yang tidak memiliki gejala atau 
hanya memiliki gejala ringan seperti batuk dan demam dapat melakukan isolasi mandiri atau yang dikenal dengan isoman. Selain kondisi fisik, penilaian juga harus mencakup riwayat penyakit terdahulu (komorbid) oleh dokter. Dokter akan menilai apakah pasien boleh menjalani isolasi mandiri atau di rumah sakit.

Selain lansia yang terinfeksi, beberapa kondisi yang memerlukan isoman antara lain

- $\quad$ Tinggal dengan orang yang memiliki gejala COVID-19

- Memiliki riwayat perjalanan atau tinggal di daerah yang endemis COVID-19 (baik di dalam maupun di luar negeri) dalam 14 hari terakhir

Isolasi mandiri dilakukan untuk menjaga orang di sekitar kita tidak tertular dan memudahkan pemantauan oleh petugas kesehatan. Dalam menjalani isolasi mandiri terdapat beberapa hal yang perlu dipersiapkan, diantaranya

- Perlengkapan pribadi seperti pakaian dan alat mandi

- Perlengkapan ibadah

- Obat-obatan penyakit kronis

- Perlengkapan lainnya untuk mengisi kegiatan selama isoman seperti handphone, laptop, buku dan alat hobi yang dapat dikerjakan selama masa isolasi mandiri

- Perlengkapan untuk memantau suhu (termometer) dan saturasi oksigen (pulse oxymetri).

- Memasang pemberitahuan sedang melakukan isolasi mandiri pada tempat yang mudah terlihat 
Setelah mempersiapkan hal-hal tersebut, pasien juga diharapkan melakukan hal-hal berikut:

- Pola makan teratur $3 x$ sehari dengan gizi seimbang. Pola makan akan terganggu mengingat pasien akan mengalami gangguan rasa pengecap dan penghidu. Hal ini memerlukan peranan keluarga untuk mengingatkan pasien untuk makan. Buahbuahan yang mengandung vitamin dan sayur juga disarankan untuk rutin dikonsumsi selama masa isolasi mandiri

- Minum air putih 1,5-2 liter setiap hari (jika tidak ada kontraindikasi kelebihan cairan misalnya pada pasien dengan riwayat gagal ginjal)

- Pola tidur cukup dan teratur (7-8 jam sehari)

- Minum obat yang diresepkan oleh dokter sesuai dengan dosis dan jadwal

- Minum vitamin C, D dan Zinc setiap hari

- Mengukur suhu badan setiap pagi dan sore hari

- Mengukur saturasi oksigen setiap pagi dan sore, atau jika pasien merasakan sesak

- Memantau gejala yang dirasakan dan melaporkan ke puskesmas/klinik secara berkala

- Melakukan komunikasi dengan anggota keluarga lain secara online atau dengan memakai masker dan menjaga jarak minimal 1 meter.

- Mencuci alat makan sendiri/terpisah dengan keluarga lain

- Mencuci baju terpisah dengan keluarga yang lain

- Membuka jendela kamar setiap hari 
- Melakukan aktivitas fisik ringan selama 20-30 menit yang disesuaikan dengan kemampaun lansia

Hal-hal yang tidak boleh dilakukan selama isolasi mandiri antara lain

- Makan bersama dengan anggota keluarga yang lain

- Berkumpul dengan anggota keluarga yang lain

- Menggunakan perangkat komunikasi yang sama dengan anggota keluarga lain

- Keluar rumah kecuali dalam kondisi mendesak atau harus kontrol ke fasilitas kesehatan

\section{CARA MENJAGA LANSIA SELAMA ISOMAN DI RUMAH}

Berikut beberapa tips yang dapat Anda lakukan kepada keluarga lansia saat karantina mandiri:

- Jaga Lansia Agar Tetap Aktif

Untuk mengisi masa karantina mandiri di rumah selama masa pandemi, sebaiknya jaga lansia tetap aktif secara fisik. Ajaklah lansia untuk berolahraga ringan, seperti jalan santai di dekat rumah, senam lansia, ataupun yoga.

- Memberikan semangat

Lansia sangat rentan jatuh dalam keadaan putus asa. Keluarga dapat mengambil peranan dengan menciptakan lingkungan yang positif, penuh perhatian dan dukungan kepada lansia untuk melewati masa-masa sulit.

- Komunikasi ruti dengan anggota keluarga 
Agar selalu terhubung dengan keluarga, bantu lansia untuk tetap menghubungi anggota keluarga lain melalui telepon, teks atau video call. Selain untuk mengisi waktu luang, juga agar mereka tidak merasa terisolasi.

- Buat Nyaman Lansia Selama Karantina

Selama menjalankan masa karantina mandiri, selain memberikan perhatian dan kasih sayang kepada mereka, jangan lupa untuk memperhatikan perawatan lansia sehari-hari.

Sebagian besar lansia mengalami gangguan berkemih. Angka kejadian gangguan berkemih pun meningkat seiring bertambahnya usia. Hal ini dinamakan inkontinensia urine, yaitu sebuah kondisi saat kandung kemih tidak dapat dikontrol sehingga sering buang air kecil tanpa disadari (mengompol). Gangguan inkontinensia urine pada lansia disebabkan oleh melemahnya saraf yang mengontrol katup kandung kemih. Kondisi ini tentu akan membuat lansia tidak nyaman, terutama ditambah kondisi pandemi saat ini.

Agar mereka tetap merasa nyaman, pastikan area di dalam rumah, terutama area menuju kamar mandi dan kamar mandi tidak terlalu jauh dari area tempat tidur. Apabila frekuensi ke kamar mandi terlalu sering, disarankan untuk memakai popok dewasa agar terhindar dari risiko jatuh. Hal ini juga penting agar mereka tidak bertambah resah karena harus bolak-balik ke kamar mandi.

Gunakan popok dewasa dua kali di siang hari dan satu kali di malam hari. Pastikan daya serap dan tampung urine baik sehingga terhindar dari kebocoran urine selama pemakaian. Dan, untuk mencegah terjadinya iritasi di area sekitar selangkangan, gunakan popok yang 
mengandung aloe vera. Pastikan selama masa karantina, lansia yang ada di rumah Anda merasa nyaman, aman, dan terhindari dari stres yang berpotensi menurunkan imunitas akibat peningkatan hormone-hormon stress seperti kortisol.

\section{HAL-HAL YANG PATUT DIWASPADAI SAAT ISOMAN PADA LANSIA}

Selama dalam isolasi mandiri, pasien dan keluarga harus mewaspadai beberapa hal berikut

- Keluarga harus mewaspadai apabila pasien tampak mengalami perubahan perilaku, menjadi lebih diam dan cenderung tertidur. Hal ini dapat diikuti dengan gangguan konsentrasi dan gangguan orientasi waktu, tempat dan ruang disertai dengan gangguan atensi, mengamuk atau sulit komunikasi

- Pasien tidak mampu makan dan minum, disertai dengan kehilangan cairan seperti muntah atau diare.

- Demam tinggi yang terus menerus $>39^{\circ}$ Celsius yang tidak membaik dengan pemberian obat penurun demam dan minum air putih yang cukup

- Batuk dan sesak nafas yang memberat. Jika tersedia oksimetri dapat mengukur secara mandiri, jika saturasi oksigen < $94 \%$ pasien sudah indikasi untuk perawatan di rumah sakit. 


\section{DAFTAR PUSTAKA}

Perhimpunan Dokter Spesialis Penyakit Dalam Indonesia (PAPDI). 2020. Buku Panduan Isoman. Jakarta: Perhimpunan Dokter Spesialis Penyakit Dalam (PAPDI).

Kementerian Kesehatan Republik Indonesia. 2021. Paket Advokasi Vaksinasi COVID-19 Lindungi Diri, Lindungi Negeri. Diakses melalui https://cdn.who.int/media/docs/default-source/ pada 3 Agustus 2021.

World Health Organizarion. WHO Coronavirus Disease (COVID-19). Diakses melalui https://covid19.who.int/ pada 3 Agustus 2021.

World Health Organization. Guidance on COVID-19 for the care of older people and people living in long-term care facilities, other non acute care facilities and home care. Diakses melalui https://covid19.who.int/ pada 3 Agustus 2021.

Brooke, J. and Jackson, D. 2020. Older people and COVID-19: Isolation, risk and ageism. J Clin Nurs, 29: 2044-2046.

Armitage, R. and Nellums, L.B., 2020. COVID-19 and the consequences of isolating the elderly. The Lancet Public Health, 5(5), p.e256. 


\section{COVID-19 DAN CEDERA KEPALA}

Tjokorda Gde Bagus Mahadewa

COVID-19 saat ini sudah menjadi kata-kata yang sering kita dengar dan menjadi berita-berita utama di berbagai media. Banyak hal mengenai COVID-19 beredar di sekitar kita baik itu dari keluarga, lingkungan rumah, tempat kerja sampai dengan media-media sosial yang berbeda-beda. Hal ini membuat banyak munculnya pemahaman pemahaman tentang COVID-19 yang salah karena tidak sedikit juga orang - orang yang menyebarkan berita tidak benar mengenai penyakit ini untuk mengambil keuntungan pribadi atau perorangan. Hal ini menyebabkan perlunya kita meningkatkan pemahaman dan pengertian mengenai infeksi COVID-19 ini dengan cara membaca atau mendengarkan hal - hal mengenai peyakit ini dari sumber - sumber yang relevan dan terpercaya.

Berikut akan ditampilkan hal - hal umum yang berkaitan tentang COVID-19 seperti mengenai apa itu covid, bagaimana cara penularannya, apa saja gejala - gejala yang bisa didapatkan, beserta pencegahan dan penanganan yang dapat kita lakukan. Hal ini dimaksudkan agar masyarakat lebih banyak mendapatkan referensi referensi mengenai COVID-19 dari sumber - sumber yang terpercaya. Dengan banyaknya bermunculan penjelesan tentang COVID-19 dari sumber yang relevan diharapkan kita dapat terhindar dari berita - berita tidak benar mengenai penyakit ini. Pada akhirnya diri kita sendirilah yang berperan dalam mencegah penyebaran penyakit ini dengan tetap mencari informasi dari sumber terpercaya dan tetap melakukan protokol Kesehatan 6M yaitu memakai masker, mencuci tangan, menjaga jarak, 
menjauhi kerumunan, membatasi mobilitas dan saat ini dapat ditambahkan juga dengan melakukan vaksin.

\section{MENGENAL COVID-19 DAN CEDERA KEPALA}

\section{Apa itu COVID-19?}

Pada tanggal 8 Desember 2019, muncul satu jenis pneumonia baru yang kemudian menyebar ke seluruh dunia. Pneumonia ini kemudian dikenal sebagai Corona Virus Disease 2019 (COVID-19) yang masuk ke Indonesia dan diumumkan secara resmi oleh Presiden RI pada tanggal 2 Maret 2020. Lalu didapatkan bahwa COVID-19 disebabkan oleh virus baru dari golongan virus corona. Kemudian dikategorikan bahwa COVID-19 ini disebabkan oleh virus baru yang disebut dengan virus SARS-COV 2 yang sekarang menjadi pandemi di seluruh dunia.

COVID-19 sangat berbahaya karena penularannya cepat dan mudah terjadi mutasi membentuk varian baru yang saat ini disebut dengan varian Alpha, Beta, Delta dan Gamma dengan keunikannya masing - masing. Varian Alpha berasal dari mutasi di Inggris, varian Beta dari mutasi di Afrika Selatan, varian Delta dari mutasi di India, dan varian Gamma dari mutasi di Brasil.

\section{Bagaimana COVID-19 menular?}

Penularan COVID-19 bisa dikatakan sangat cepat dan tidak terkendali. Pada awal kemunculannya penularan penyakit COVID-19 ini masih menjadi sesuatu hal yang misterius karena dianggap penularan yang terjadi adalah melalui transmisi dari hewan ke manusia dimana awal kasus penyakit ini berasal dari pasar hewan di Wuhan, China. Tetapi saat ini didapatkan bahwa penyebaran COVID-19 dapat terjadi transmisi dari 
orang ke orang yang menyebabkan penyebaran penyakit ini semakin cepat. Transmisi dapat terjadi secara langsung secara droplet yaitu percikan langsung dari jarang 1-2 meter dari orang yang berbicara, batuk ataupun bersin tanpa ditutup dan dapat juga secara langsung dari droplet yang mengenai permukaan benda dan terpegang lalu dimana orang yang bersangkutan menyentuh wajahnya. COVID-19 dapat menular sejak 48 jam sebelum muncul gejala hingga 14 hari setelah muncul gejala.

Saat ini total kasus konfirmasi per tanggal 24 Juli adalah 3.127.826 pasien dengan jumlah kematian 82.013 dengan total kasus aktif 574.135 kasus dimana data - dara tersebut dapat kita pantau dari Kemenkes.

\section{Gejala COVID-19}

Gejala dari COVID-19 sangat bervariasi hingga saat ini. Gejala yang dirasakan seseorang dapat berupa gejala ringan, sedang, sampai berat. Gejala ringan dan sedang yang dialami oleh seseorang dapat berupa demam, rasa lelah, dan batuk kering. Beberapa orang mungkin mengalami rasa nyeri dan sakit. Hidung tersumbat, pilek, nyeri kepala, konjungtivitis, sakit tenggorokan, diare, hilang penciuman dan pembauan atau ruam kulit. Gejala berat pada COVID-19 dapat berupa kesulitan bernafas dengan nafas yang pendek, nyeri pada dada dan terasa tekanan pada dada, penurunan kesadaran atau sering mengantuk, pada kondisi lebih berat hingga menyebabkan kuku, bibir dan kulit tampak kebiruan.

Hal yang perlu diingat adalah bahwa tidak semua orang yang memiliki gejala seperti di atas terkena COVID-19, dan tidak semua orang dengan COVID-19 memiliki gejala. Konfirmasi harus dilakukan dengan Swab PCR. Jika ada gejala maka harus dilakukan swab. Bila hasil PCR 
Test negatif tetap di rumah, patuhi prokes, dan swab ulang 7-10 hari lagi. Bila hasil PCR Test positif lakukan isolasi mandiri, bila gejala memberat kunjungi RS. Selain bergejala, jika kita didapatkan kontak erat, kita harus tetap melakukan pemeriksaan. Yang dimaksud dengan kontak erat adalah tatap muka berdekatan dalam jarak 1 meter selama 15 menit, bersentuhan secara fisik, merawat pasien COVID-19 tanpa APD yang standar.

\section{Pencegahan dan Penanganan COVID-19}

Pencegahan COVID-19 merupakan langkah utama yang harus dilakukan untuk menekan penyebaran penyakit ini. Hal - hal mengenai pencegahan penyakit COVID-19 sudah sering disebarkan melalui media -media sosial saat ini. Sebagai warga negara, kita wajib untuk menjalankan Protokol Kesehatan yang telah menjadi program pemerintah. Hal - hal yang dapat dilakukan adalah menggunakan masker, selalu menjaga jarak, sering cuci tangan, makan - makanan yang bergizi, olahraga yang teratur, dan menggunakan uang elektronik dibanding uang tunai.

Saat ini terdapat program Vaksinasi untuk COVID-19 dari pemerintah yang dapat kita ikuti. Vaksinasi dapat mengurangi resiko seseorang terkena COVID-19 dan dapat mengurangi beratnya gejala jika terinfeksi COVID-19.

Jika terinfeksi oleh COVID-19 pengobatan sebaiknya dilakukan berdasarkan hasil konsultasi dengan dokter bukan semata-mata berdasarkan informasi yang tidak dapat dipertanggung jawabkan kebenarannya. Jangan pernah mencoba untuk mengobati sendiri atau mengikuti saran dari bukan tenaga medis yang justru dapat 
memperburuk kondisi. Pengobatan pada kasus COVID-19 tergantung dari derajat penyakit yang dialami. Jika tanpa gejala dapat melakukan isolasi mandiri di rumah dengan konsumsi vitamin seperti Vitamin C 500 $1000 \mathrm{mg} /$ hari, dianjurkan multivitamin yang mengandung vitamin C, B, E, dan zinc serta Vitamin D 400-1000 IU / hari. Untuk pasien dengan gejala ringan dapat ditambah antivirus yang dapat digunakan Favipiravir $1600 \mathrm{mg} / 12$ jam pada hari pertama dilanjutkan 2 × $600 \mathrm{mg}$ pada hari ke2 hingga ke-5, serta obat -obat lain sesuai gejala yang dialami, untuk gejala sedang dan berat sebaiknya berobat ke rumah sakit.

Saat ini beredar mengenai obat bernama ivermectin. Ivermectin di Indonesia terdaftar sebagai obat untuk infeksi kecacingan. Hingga kini, WHO tidak merekomendasikan penggunaan ivermectin pada infeksi COVID-19.

\section{Mengenal Cedera Kepala}

Cedera kepala adalah cedera yang diakibatkan adanya mekanisme benturan atau penetrasi pada kepala yang dapat menyebabkan gangguan fungsi otak. Berdasarkan keparahannya, cedera kepala digolongkan menjadi ringan, sedang berat. Pengobatan cedera kepala berbeda-beda berdasarkan tingkat keparahan cedera kepala.

\section{PEDOMAN ISOLASI MANDIRI PADA PASIEN CEDERA KEPALA RINGAN}

\section{Cedera Kepala dalam Pandemi COVID-19}

Penanganan cedera kepala berbeda-beda tergantung derajat dari cedera kepala. Namun, Prinsip penanganan cedera kepala adalah 
melakukan pengawasan secara ketat pada pasien cedera kepala dan memberikan kondisi optimal pada otak untuk pulih. Namun pada situasi pandemic COVID-19 seperti saat ini hal tersebut sulit dilakukan, mengingat terus meningkatnya jumlah kasus COVID-19 hingga membuat tenaga medis hingga rumah sakit kewalahan. Untuk mengungari resiko penyebaran COVID-19 dirumah sakit, pada pasien dengan cedera kepala derajat sedang dan berat tetap memerlukan pengawasan dirumah sakit, sedangkan pada kasus cedera kepala ringan pasien dapat melakukan pengawasan secara mandiri bersama keluarga (isolasi mandiri).

\section{Pedoman isolasi mandiri pada pasien cedera kepala ringan}

Isolasi mandiri diperuntukan mereka yang terinfeksi COVID-19 tanpa gejala atau dengan adanya gejala ringan yang berujuan untuk mencegah penyebaran infeksi COVID-19 yang lebih lanjut pada masyarakat.

Pedoman isolasi mandiri bagi pasien

- Tidur di kamar terpisah: upayakan tidur dan beraktivitas di kamar yang terpisah agar tidak menularkan virus COVID-19 kepada anggota keluarga

- Rajin mencuci tangan: mencuci tangan dapat dilakukan menggunaan dengan alir mengalir dan sabun. Selalu sediakan dan gunakan hand sanitizer

- Menggunakan masker ganda: gunakanlah masker ganda (2 lapis) dimana masker bedah di bagian dalam dan masker kain di bagian luar 
- Menjaga jarak: tetap menjaga jarak dengan keluarga. Jika hendak keluar kamar, pastikan tetap menggunakan APD yang benar dan mengaja jarak dengan anggota keluarga lain

- Cuci perabot makanan: gunakan alat makan yang berbeda dengan anggota keluarga yang lain. Penggunaan perabot makanan sekali pakai dapat dipertimbangkan. Pastikan alat makan dicuci dengan sabun cuci piring

- Berjemur: berjemur dapat dilakukan setiap hari selama 10-15 menit, sebelum pukul 09.00 atau sesudah 15.00

- Apa yang harus di pantau selama isolasi mandiri?

- Pengukuran suhu tubuh secara rutin, pagi, dan malam. Bila suhu $>37.5^{0}$ segera laporkan

- Pengukuran saturasi oksigen secara rutin, bila didapatkan saturasi $<95 \%$ segera laporkan

- Tanda-tanda perburukan kondisi seperti nyeri kepala yang bertambah berat, muntah-muntah, vertigo yang bersifat baru atau gejalanya memberat, kejang, serta penurunan kesadaran, segera laporkan.

Pedoman isolasi mandiri pada pasien

Keluarga sangat penting untuk memberikan dukungan serta semangat untuk pemulihan pasien

- Tracing: bagi anggota keluarga yang melakukan kontak erat dengan pasien perlu memeriksakan diri ke fasilitas kesehatan primer untuk melakukan pemeriksaan dan mengevaluasi kepentingan swab PCR COVID-19. 
- APD: keluarga yang akan kontak erat selama isolasi mandiri diwajibkan untuk tetap menggunakan alat pelindung diri (APD) seperti face shield, masker, sarung tangan, sanitizer

- Jaga Jarak: membatasi kontak erat dengan pasien tetap menjaga jarak minimal 1 meter

- Desinfeksi: Sesering mungkin melakukan desinfeksi dengan minimal menggunakan desinfeksi rumah tangga pada daerah yang sering disentuh atau lingkungan sekitar perawatan pasien

- Cuci tangan: menerapkan prinsip 5 momen cuci tangan :

- Sebelum menyentuh pasien

- Sebelum melakukan perawatan pada pasien

- Setelah terkena cairan tubuh pasien

- Setelah melakukan kontak dengan pasien

- Setelah menyentuh lingkungan sekitar pasien

\section{Terapi Farmakologi Untuk Pasien Cedera Kepala Ringan}

Obat-obatan serta vitamin yang dapat dikonsumsi pasien dengan cedera kepala ringan yang menjalani isolasi mandiri:

- Obat-obat didapat dirumah sakit dapat dilanjutkan, seperti anti nyeri, anti mual, dan anti kejang

- Vitamin:

○ Vitamin $\mathrm{C}$ dapat diberikan dengan dosis 500mg setiap 68jam

○ Vitamin D dapat diberikan dengan dosis 400IU - 1000 lu/hari

○ Vitamin E dapat diberikan dengan 400-1000 IU/hari 


\section{Terapi farmakologi untuk pasien cedera kepala ringan}

Selain pengobatan medis, pasien cedera kepala tetap harus meningkatkan kesehatan serta ketenangan pikiran selama melakukan isoman

- Pikiran: sangat penting untuk selalu menenangkan pikiran dengan berpikir hal-hal positif dan berkomunikasi dengan keluarga mengentahui ada keluarga atau kerabat sangat menenangkan bagi mereka yang menjalani isoman

- Tubuh: Konsumsi air yang cukup disertai makanan yang teratur dan bergizi serta olahraga ringan dapat membantu proses pemulihan

- Jiwa: berdoa merupakan hal yang penting untuk dapat menciptakan aura positif dan menengkan jiwa yang membantu proses pemulihan

\section{Kondisi cedera kepala ringan disertai COVID-19 yang memerlukan perawatan dirumah sakit}

- Nyeri kepala yang baru muncul atau semakin memberat

- Muntah proyektil (muntah menyemprot)

- Pusing berputar (vertigo) yang baru muncul atau semakin berat

- Kejang dan sulit dibangunkan

- Demam tinggi, saturasi $<96 \%$

Sebagai salah satu upaya penanggulangan COVID-19 pemerintah mengkampanyekan program isolasi mandiri, isolasi mandiri diperuntukan bagi mereka yang terinfeksi COVID-19 tanpa gejala atau dengan gejala ringan yang bertujuan untuk mencegah penyebaran infeksi COVID-19 yang lebih lanjut pada masyarakat. Guna mendukung program isolasi 
mandiri tersebut, diperlukanlah suatu pedoman yang dapat memberikan informasi kepada pasien/masyarakat, buku ini diharapkan dapat membantu memahami sehingga dapat membimbing mereka dalam menjalani isolasi mandiri khususnya pada pasien cedera kepala ringan dan sedang terinfeksi COVID-19.

\section{DAFTAR PUSTAKA}

Direktorat Jendral Pencegahan dan Pengendalian Penyakit. Pedoman Pencegahan dan Pengendalian Coronavirus Disease (COVID-19) Revisi ke-5. 5 ed: Kementerian Kesehatan RI; 2020.

Direktur Jenderal Pelayanan Kesehatan. Protokol Tata Laksana COVID19 buku saku edisi 2. Kementrian Kesehatan RI; 2021.

Goyal N, Swain SK, Gupta K, et al. "Locked up inside home" - Head injury patterns during coronavirus diseae disease of 2019 pandemic. Surgical Neurology International. 2020;11:395.

Santing, JAL, van den Brand, CL, Jellema K. Traumatic brain injury during the SARS-CoV-2 pandemic. Neurotrauma Reports. 2020.1:1, 5-7. 


\section{PANDUAN ISOMAN PROBLEM NEUROLOGI PADA PASIEN COVID-19}

Ni Made Susilawathi, Kumara Tini

\section{MENGENAL COVID-19}

- COVID-19 merupakan infeksi saluran nafas yang sangat menular dengan gejala yang sering muncul berupa:

○ batuk,

○ demam

- gangguan perasa atau penghidu

- Gejala diatas mungkin mirip dengan gejala infeksi yang lain, bila masih ragu-ragu dan khawatir dengan gejala yang dialami sebaiknya segera berkonsultasi dengan dokter di fasilitas layanan kesehatan (Fasyankes) terdekat untuk mendapatkan arahan dan pertolongan pertama.

Berikut dibawah ini beberapa informasi terkait problem neurologi pada pasien COVID-19 dan apa yang sebaiknya dilakukan terutama pada penderita dengan isolasi mandiri.

\section{Apakah COVID-19 berdampak pada sistem saraf dan menimbulkan keluhan neurologi?}

- COVID-19 walaupun bergejala awal sebagai gejala infeksi saluran nafas atas, namun infeksi dapat berkembang terutama pada pasien yang rentan menjadi penyakit yang menimbulkan peradangan di banyak organ tubuh dan pembuluh darah termasuk sistem saraf.

- COVID-19 dapat menimbulkan berbagai gejala neurologis, dari yang ringan (sakit kepala, pusing berputar dan nyeri otot) hingga 
yang berat (gangguan kesadaran, kejang, stroke dan meningitis/ensefalitis) bahkan dapat merupakan gejala awal COVID-19 seperti gangguan saraf penciuman dan perasa.

- COVID-19 juga dapat memperberat kondisi pasien dengan problem neurologis terutama pada pasien stroke dan parkinson dengan diabilitas yang berat dan pasien gangguan imun seperti multiple sckeloris (MS) dam Myasthenia Gravis (MG) yang menggunakan imunospupresan.

\section{Apa yang dilakukan untuk mengurangi risiko terinfeksi virus corona?}

- Ikuti saran Pemerintah untuk membantu mengendalikan penyebaran COVID-19.

- Berikut ini langkah-langkah untuk melindungi diri sendiri agar terhindar dari COVID-19

- rajin mencuci tangan dengan sabun dan air mengalir selama 20 detik

- hindari menyentuh area mata, hidung dan mulut

- bila batuk dan bersin tutup dengan tissue dan buang pada tempat sampah yang ditentukan

- selalu memakai masker saat keluar rumah

- jaga jarak minimal 1 meter dengan orang lain

- hindari kontak dengan orang yang sedang sakit

- bersihkan dan desinfeksi benda yang sering disentuh

\section{Apa yang dilakukan bila bergejala COVID-19?}

- Apabila muncul gejala COVID-19 sebaiknya tetap tinggal di rumah dan hubungi Fasyankes terdekat untuk melakukan tes konfirmasi COVID-19 berupa tes swab PCR atau antigen. 
- Seseorang dengan hasil tes positif COVID-19 dengan atau tanpa gejala harus tinggal di rumah dan melakukan isolasi mandiri karena dapat menularkan infeksi ini kepada orang lain.

- Ikuti panduan pemerintah bila menjalani isolasi mandiri.

\section{Bagaimana dengan seseorang yang telah mendapatkan vaksinasi COVID-19?}

- Jika seseorang telah mendapatkan vaksinasi maka risiko tertular COVID-19 menjadi lebih rendah sehingga kemungkinan menularkan juga berkurang.

- Protokol kesehatan untuk mengurangi terpapar COVID-19 harus tetap dilaksanakan meskipun sudah divaksinasi.

- Apabila seseorang yang sudah divaksinasi mengalami gejala COVID-19 atau menerima hasil yang positif maka tetap harus mengikuti panduan layanan kesehatan untuk tetap di rumah dan isolasi mandiri agar mengurangi risiko penyebaran infeksi kepada orang lain.

\section{APA YAG HARUS DILAKUKAN BAGI SESEORANG DENGAN PROBLEM NEUROLOGI DI MASA PANDEMI COVID-19?}

Penyakit neurologi yang dialami pasien sangat bervariasi dengan risiko terpapar COVID-19 dan keparahan penyakit juga sangat beragam.

Risiko ini tergantung pada:

- Usia

Usia tua memiliki risiko yang berat terpapar COVID-19

- Masalah neurologi yang dialami 
Pasien dengan demensia, gangguan menelan dan kelemahan yang berat lebih rentan terpapar COVID-19.

- Penyakit penyerta lainnya

Penyakit sistemik seperti DM, Hipertensi dan penyakit jantung dapat meningkatkan keparahan penyakit.

- Pengobatan yang sedang berjalan

Obat imunusuppresan yang rutin diminum oleh pasien neurologi lebih rentan terpapar COVID-19.

\section{EPILEPSI DAN COVID-19}

\section{Apakah epilepsi meningkatkan risiko terjadinya COVID- 19?}

- Epilepsi tidak meningkatkan risiko terjadinya COVID-19 dan derajat keparahan COVID-19.

- Diskusikan dengan dokter yang merawat tentang risiko COVID19 dan ikuti program pengobatan yang telah ditentukan.

\section{Apa saja yang perlu diketahui bagi penyandang epilepsi bila terpapar COVID-19?}

- Kontrol kejang sangat penting pada kondisi terinfeksi, maka minum obat anti-epilepsi sesuai dosis dan waktu yang tepat sangat diperlukan.

- Pasien epilepsi disertai problem neurologi yang lain atau gangguan sistemik (DM, penyakit jantung atau paru) akan lebih berisiko tertular COVID-19 dengan gejala lebih berat sehingga perlu memperhatikan kondisi sistem kekebalan tubuhnya.

- Konsultasi ke Fasyankes terdekat atau dokter yang merawat bila memiliki kondisi yang meningkatkan risiko COVID-19 dan ikuti 
langkah-langkah pencegahan untuk menghindari terpapar COVID-19.

\section{STROKE DAN COVID-19}

\section{Apakah stroke meningkatkan risiko terpapar COVID-19?}

- Seseorang yang pernah mengalami stroke (penyintas stroke) memiliki risiko terkena COVID-19 yang sama dengan orang lain.

- Penyintas stroke harus mengontrol faktor risiko stroke dengan minum rutin obat-obat yang diberikan dan berdiskusi dengan Fasyankes terdekat atau dokter yang merawat untuk pencegahan COVID-19.

\section{Apa saja yang perlu diketahui bagi penyintas stroke bila terpapar COVID-19?}

- Penyintas stroke yang terpapar COVID-19 biasanya memiliki risiko menjadi berat akibat penyakit sistemik yang menyertainya seperti DM, Hipertensi, dan penyakit jantung serta kecacatan yang terjadi pasca stroke (gangguan menelan dan kelumpuhan yang berat).

- Setiap penyintas stroke memiliki masalah kesehatan yang tidak sama, maka kenali dengan baik problem kesehatan masingmasing dan lakukan konsultasi dengan dokter yang merawat untuk mengurangi keparahan penyakit.

- Seseorang dengan pengobatan anti pembekuan darah seperti warfarin harus berdiskusi dengan dokter untuk pemeriksaan darah rutin agar tetap mempertahankan kadar INR yang sesuai.

- Penyintas stroke yang terpapar COVID-19 dengan penyakit penyerta seperti DM, hipertensi sebaiknya segera berkonsultasi 
dengan Fasyankes terdekat yang melayani COVID-19 sehingga dapat dipantau dengan lebih teliti kemungkinan penderita mengalami perburukan COVID-19.

\section{Apakah COVID-19 dapat menyebabkan stroke dan keluhan apa saja yang perlu diwapadai?}

- COVID-19 dapat menimbulkan peradangan diseluruh tubuh termasuk pembuluh darah otak. Peradangan pembuluh darah menyebabkan peningkatan pembentukan gumpalan darah sehingga dapat menimbulkan stroke sumbatan.

- COVID-19 juga dapat mengakibatkan terjadinya stroke perdarahan walaupun terhitung jarang, dan ini terjadi akibat peningkatan tekanan darah yang mendadak menimbulkan pecahnya pembuluh darah terutama pada penderita yang sudah mengalami hipertensi lama.

- Gejala stroke tergantung lokasi pembuluh darah otak yang tersumbat dan area otak yang mengalami kerusakan, bersifat mendadak dengan gejala seperti:

○ Kelemahan separuh tubuh termasuk wajah

- Bicara yang tidak jelas

- Kehilangan penglihatan

- Gangguan keseimbangan dan vertigo (sekeliling terasa berputar)

- Sakit kepala mendadak

○ Kejang

- Bila seseorang terpapar COVID-19 mengalami gejala diatas, segera menghubungi Fasyankes terdekat dan jangan ditunda untuk meminta bantuan agar mengurangi kecacatan dan kematian akibat stroke. 


\section{PARKINSON DAN COVID-19}

\section{Apakah Parkinson meningkatkan risiko terpapar COVID-19?}

- Pasien Parkinson memiliki risiko yang sama dengan orang lain untuk terpapar COVID-19.

- Namun pasien Parkinson biasanya berusia lanjut sehingga lebih rentan terkena infeksi termasuk COVID-19 akibat daya tahan tubuh yang menurun dan disertai adanya penyakit penyerta lainnya.

\section{Apakah yang perlu diketahui pasien Parkinson bila terpapar COVID-19?}

- Pasien Parkinson memerlukan pengobatan rutin yang diminum tepat dosis dan waktu pemberian agar dapat beraktivitas optimal untuk menghindari keparahan penyakit.

- Gejala Parkinson dapat memberat bila pasien sedang dalam kondisi sakit dan stress. Konsultasi ke dokter yang merawat untuk penyesuaikan pengobatan yang rutin diminum.

- Gejala non motorik seperti kecemasan, depresi dan apatis dapat memberat bila pasien dalam kondisi sakit. Keluarga atau pengasuh harus memperhatikan perubahan mental yang terjadi dan segera berkonsultasi ke dokter yang merawat.

- Pengobatan simptomatis untuk COVID-19 dapat mempengaruhi kondisi pasien Parkinson yang juga rutin minum berbagai obat untuk mengontrol penyakitnya. Diskusikan dengan dokter yang merawat untuk pemilihan obat yang sesuai. 


\section{MULTIPLE SKLEROSIS DAN COVID-19}

\section{Apakah multiple sklerosis (MS) meningkatkan risiko terpapar COVID-19?}

- Pasien MS memiliki risiko yang sama dengan orang lain untuk terpapar COVID-19

- Pasien MS yang sedang dalam program pengobatan imunusupressan perlu hati-hati karena beberapa obat dapat menekan sistem kekebalan tubuh sehingga memiliki risiko lebih tinggi untuk terinfeksi.

- Pasien MS dengan disabilitas berat atau yang mengalami perburukan gejala neurologis seperti kesulitan menelan sangat rentan terhadap infeksi.

- Diskusikan dengan dokter untuk langkah pencegahan COVID-19

\section{Apa saja yang perlu diketahui bagi pasien MS bila terpapar COVID-19?}

- Pasien MS terpapar COVID-19 dengan usia lebih tua, disabilitas yang berat, adanya penyakit peryerta lain seperti penyakit kardiovaskular dan hipertensi berisiko menimbulkan gejala yang lebih parah.

- Infeksi pada pasien MS termasuk COVID-19 mungkin akan dapat memicu gejala baru MS atau memperburuk problem neurologi yang telah ada.

- Pasien MS terpapar COVID-19 yang sedang terapi immunosuppresan juga dapat meningkatkan risiko keparahan penyakit. 
- Segera berkonsultasi dengan dokter yang merawat bila terjadi peningkatan aktivitas MS dan untuk pengelolaan terapi imunosupresan yang digunakan.

\section{TIPS MENJAGA KESEHATAN FISIK DAN MENTAL TETAP BAIK SELAMA ISOLASI MANDIRI}

- Lakukan aktifitas rutin di rumah semampunya seperti olahraga ringan dan berkegiatan sesuai dengan hobi sehingga dapat membantu menjernihkan pikiran.

- Lakukan aktifitas membaca, menulis, mengisi teka-teki silang dan menelpon teman atau anggota keluarga lainnya untuk menghilangkan kejenuhan dan kecemasan.

- Istirahat yang cukup dengan mempertahankan pola tidur yang baik.

- Jaga pola makan tetap sehat dan seimbang.

- Buka jendela rumah agar tetap memperoleh udara segar.

- Usahakan rutin mendapat sinar matahari langsung. 


\section{DAFTAR PUSTAKA}

American Academy of Neurology. 2020. COVID-19 Neurology Resource Center. Diakses melalui https://www.aan.com/tools-andresources/COVID-19-neurology-resource-center/ pada 3 Agustus 2021.

Epilepsy Foundation. 2020. COVID-19 and Epilepsy. Diakses melalui https://www.epilepsy.com/learn/COVID-19-and-epilepsy\#: :text= People\%20with\%20epilepsy\%20may\%20have,at\%20higher\%20ri sk\%20for\%20pneumonia pada 3 Agustus 2021.

Stroke Association. 2020. Coronavirus and stroke. Diakses melalui https://www.stroke.org.uk/finding-support/coronavirus-COVID-19and-stroke pada 3 Agustus 2021.

Parkinson's Foundation. 2020. COVID-19 \&Parkinson's. Diakeses melalui https://www.parkinson.org/understanding-parkinsons/ COVID-19 pada 3 Agustus 2021.

National Multiple Sclerosis Society. 2020. Multiple sclerosis and COVID19. Diakeses melalui https://www.nationalmssociety.org/ coronavirus-COVID-19-information/multiple-sclerosis-andcoronavirus pada 3 Agustus 2021. 


\section{SINTESIS DAN PENUTUP}

Pelaksanaan isoman sesuai protokol bagi penderita COVID-19 gejala ringan dan sedang merupakan salah satu tonggak keberhasilan pengendalian COVID-19 sebagai suatu masalah kesehatan masyarakat. Peserta isoman harus memahami sarana dan prasarana yang diperlukan untuk melaksanakan isoman secara efektif dan aman di rumah masingmasing. Peserta isoman juga harus mengetahui dan taat pada protokolprotokol kesehatan yang bertujuan untuk memutus rantai penularan COVID-19.

Pada saat yang bersamaan, pelaksanaan isoman haruslah dilakukan dengan memenuhi kebutuhan-kebutuhan perawatan medis bagi peserta isoman. Perawatan mandiri yang dapat dilaksanakan peserta isoman meliputi pengawasan kondisi kesehatan pribadi secara mandiri meliputi pengawasan suhu tubuh dan saturasi oksigen untuk mengidentifikasi perburukan secara dini. Selain itu, pelaksanaan isoman yang efektif juga meliputi penyediaan obat-obatan simptomatik yang mungkin diperlukan peserta isoman seperti obat batuk, obat demam, dan multivitamin.

Pemenuhan kebutuhan perawatan medis ini juga mencakup kondisi-kondisi komorbid yang diderita peserta isoman. Peserta isoman dengan kebutuhan medis khusus harus menyadari bagaimana perawatan mandiri yang efektif untuk diri mereka sendiri. Dalam hal peserta isoman tidak dapat melakukan perawatan diri secara mandiri, keluarga atau penyedia asuhan yang bertanggung jawab haruslah 
menyadari bagaimana memberikan perawatan secara efektif dan aman dengan mempertimbangkan aspek pencegahan infeksi COVID-19.

Akhir kata, melaksanakan isoman sering kali menjadi suatu beban mental tersendiri bagi pesertanya. Oleh karena itu, peserta isoman harus lebih menyadari tingkat tekanan mental yang dialaminya dan secara aktif berusaha untuk melakukan langkah-langkah perawatan kesehatan mental. Pengenalan perburukan kesehatan mental secara dini, diikuti dengan konsultasi dengan tenaga kesehatan mental professional, dapat membantu peserta isoman beserta keluarga untuk memproses situasi yang sedang dialaminya saat ini. 


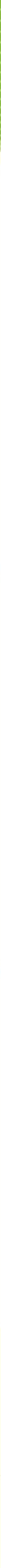

